ANL-6964

ANL-6964

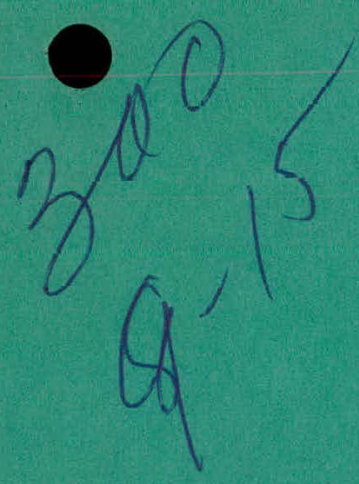

Argonne Дational Laboratom

\title{
BORAX-V NEUTRONICS
}

by

J. I. Hagen and R. W. Goin 


\section{DISCLAIMER}

This report was prepared as an account of work sponsored by an agency of the United States Government. Neither the United States Government nor any agency Thereof, nor any of their employees, makes any warranty, express or implied, or assumes any legal liability or responsibility for the accuracy, completeness, or usefulness of any information, apparatus, product, or process disclosed, or represents that its use would not infringe privately owned rights. Reference herein to any specific commercial product, process, or service by trade name, trademark, manufacturer, or otherwise does not necessarily constitute or imply its endorsement, recommendation, or favoring by the United States Government or any agency thereof. The views and opinions of authors expressed herein do not necessarily state or reflect those of the United States Government or any agency thereof. 


\section{DISCLAIMER}

Portions of this document may be illegible in electronic image products. Images are produced from the best available original document. 


\section{LEGAL NOTICE-}

This report was prepared as an account of Government sponsored work. Neither the United States, nor the Commission, nor any person acting on behalf of the Commission:

A. Makes any warranty or representation, expressed or implied, with respect to the accuracy, completeness, or usefulness of the information contained in this report, or that the use of any information, apparatus, uellivd, or proceso dibelozed in this report may not infringe privately owned rights; or

B. Assumes any liabilities with respect to the use of, or for damages resulting from the use of any information, apparatus, method, or process disclosed in this report.

As used in the above, "person acting on behalf of the Commission" includes any employee or contractor of the Commission, or employee of such contractor, to the extent that such employee or contractor of the Commission, or employee of such contractor prepares, disseminates, or provides access to, any information pursuant to his employment or contract with the Commission, or his employment with such contractor.

Printed in USA. Price $\$ 4.00$. Available from the Clearinghouse for Federal Scientific and Technical Information, National Bureau of Standards,

U. S. Department of Commerce, Springfield, Virginia 22151 
ANL-6964

Reactor Technology

(TID-4500)

AEC Research and

Development Report

\section{ARGONNE NATIONAL LABORATORY}

9700 South Cass Avenue

Argonne, Illinois 60439

BOR.AX-V NEUTRONICS

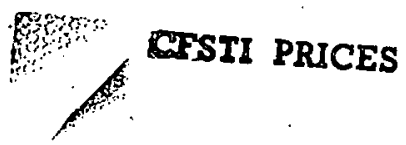

H. C. \$ ; MN

by

J. I. Hagen and R. W. Goin

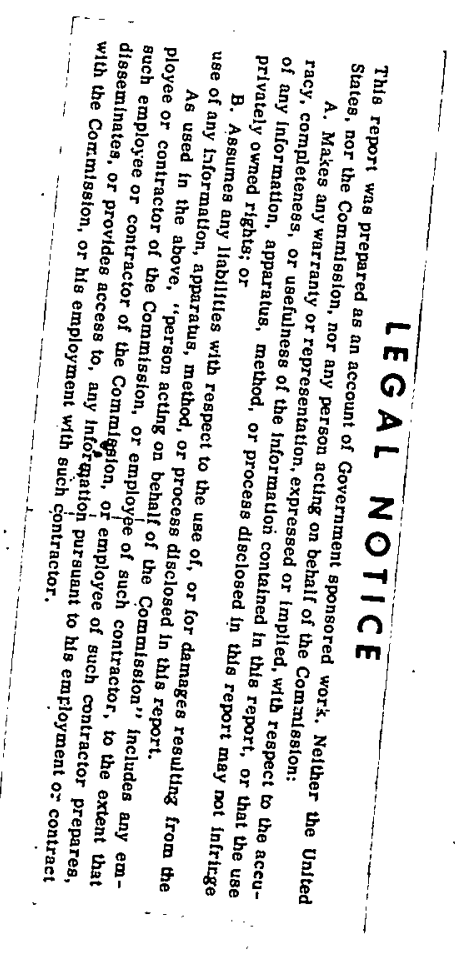

Idaho Division

RELEASED FOR ANNCUNCEMENT

IN NUCLEAR SCIENCE ABSTRACTS

December 1965

Operated by The University of Chicago

under

Contract W-31-109-eng-38

with the

U. S. Atomic Energy Commission 
TABLE OF CONTENTS

$\underline{\text { Page }}$

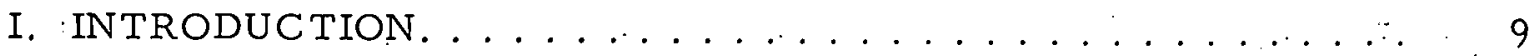

II. DEVELOPMENT OF FUEL GEOMETRY . . . . . . . . . . . . I2

A. Boiling Core..................... 12

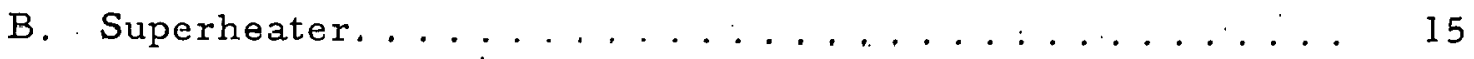

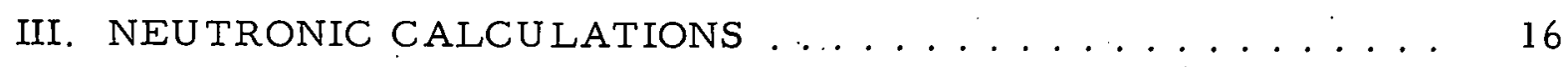

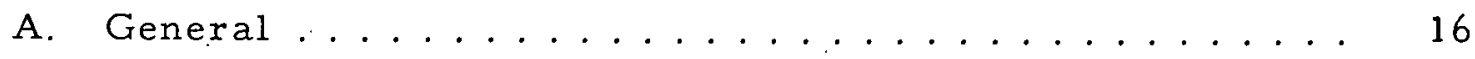

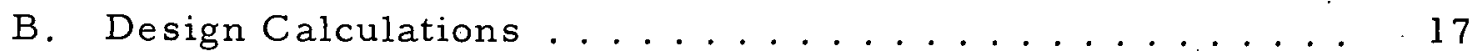

1. Disadvantage Factors and Thermal Constants ..... 21

2. Fast Cross Sections................. 23

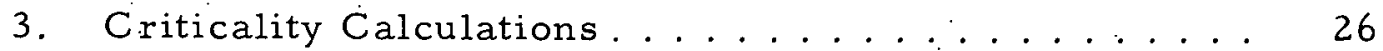

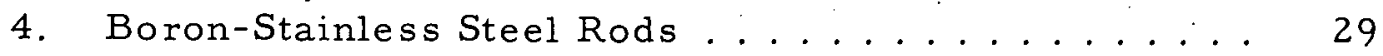

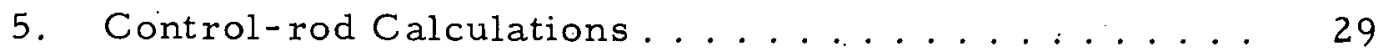

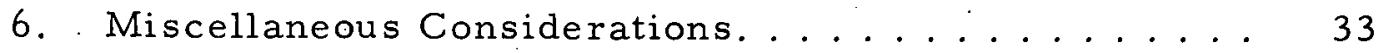

7. Experimental Comparisons ............ 38

C. Metal-to-Water Optimization Studies............ 40

1. Purpose ..................... 40

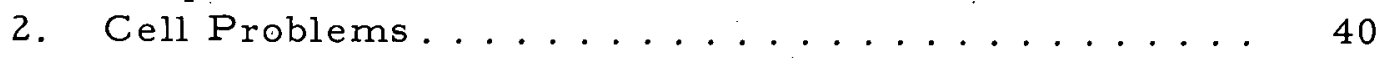

3. Reactor Problems ................. 45

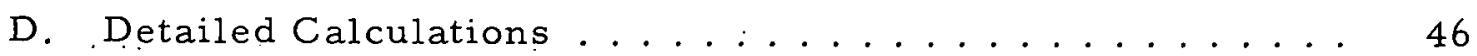

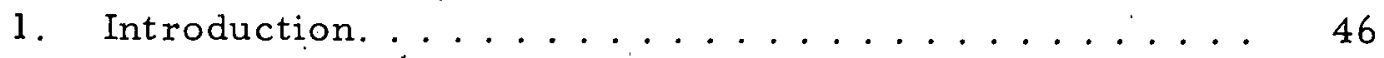

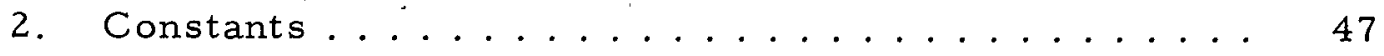

3. PDQ Problems and Results .............. 51

IV. COMPARISON WITH EXPERIMENTS . . . . . . . . . . 57

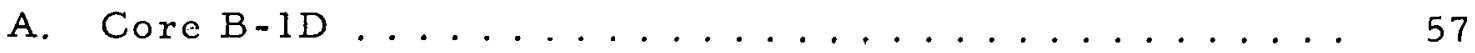

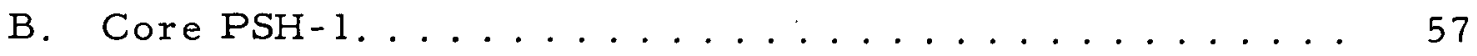

1. Control-rod Calibration and Aváilable Excess

Reactivity; Boric Acid Effect ............ 57

2. Flooding Worth ................. 62

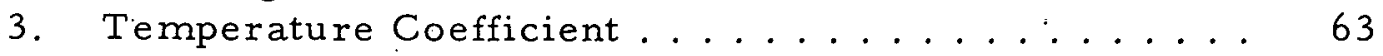

4. Power Coefficient. .................. 63

C. Neutron-flux Measurements ................ 64

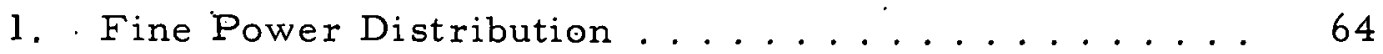

2. Axial Flux Distributions .............. 69

3. Cadmium Ratios.................. 72 
TABLE OF CONTENTS

$\underline{\text { Page }}$

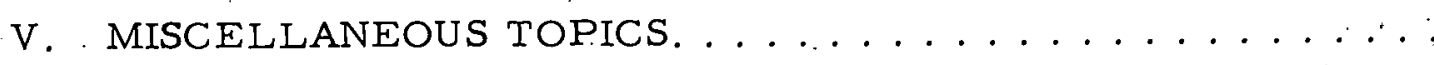

A. Approximations in Few-group Reactor-physics

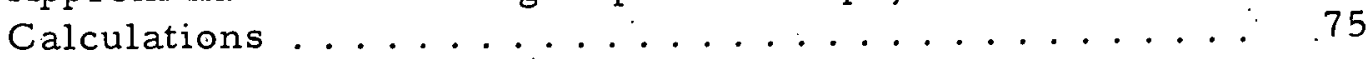

B. Superheater-Boiler Coupling . . . . . . . . . 76

1. Effective Buckling Calculation . . . . . . . . 76

2. Prediction of Operational Characteristics. . . . . . . 77

C. A TDC Calculation of the BORAX-V Exponential.

Experiment. . . . . . . . . . . . . . . 79

\section{APPENDIXES}

A. A Summary of MUFT/SOFOCATE Cross Sections for Uniformly Homogenized Cores . . . . . . . . . . . . . . 83

B. Three-group Cross-section Set Used in Flow-rod Studies ... 85

C. Atomic Densities Used in BORAX-V Core PSH-1 . . . . . . 87

D. Thermal Constants for Fuel-assembly Cell Calculations.....990

E. Four-group Constants for PDQ Calculations ...........993

F. Four-group Homogenized-fuel-region Constants from PDQ-3 for Axial Control-rod-worth Calculations, Superheaters

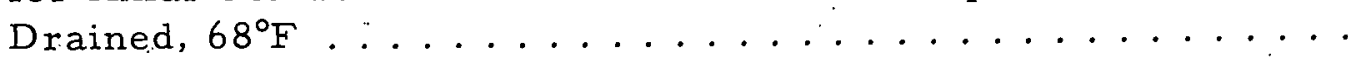

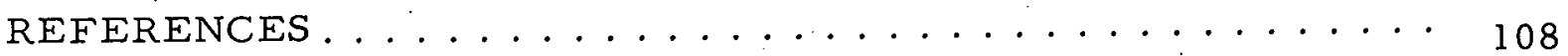




\section{LIST OF FIGURES}

Nọ.

Title

$\underline{\text { Page }}$

1. Superheating Cores..................... 10

2. A Comparison of Disadvantage Factors ............. 13

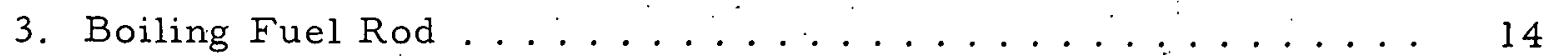

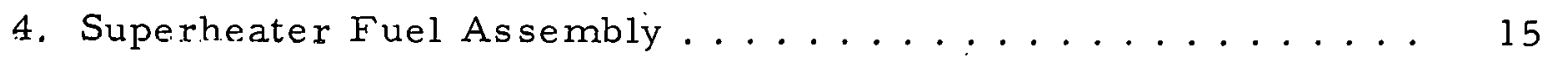

5. Diagram for Calculating Atom Densities, Boiling Region.... 19

6. Atomic Density Calculation Diagram, Superheater Fuel

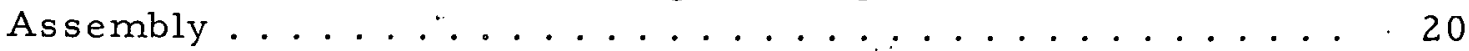

7. Calculated Disadvantage Factors. .............. 21

8. Variation of Bøiler Fuel Disadvantage Factors with Tempera-

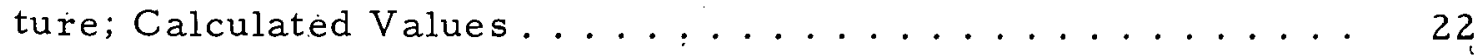

9. Fine Flux Structure in Superheater Fuel Element. . . . . . 24

10. Variation of Power Production in Superheater Fuel Plates as Related to $\mathrm{U}^{235} \mathrm{Content} \ldots \ldots \ldots \ldots . \ldots \ldots$

11. Equivalent Cylindrical Radii for One-dimensional

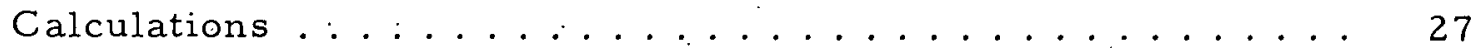

12. Calculated Reactivity Effects of. Boron-Stainless Steel Røds. . . 30

13. Dimensions and Model for Control-rod Study. . . . . . . . 32

14. Plot of Fluxes in Control-rod Region, SNG Four-group Slab

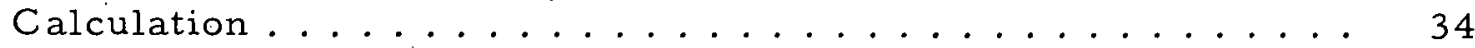

15. Calculated Reactivity of $\mathrm{CSH}$ Core with All Control Rods In

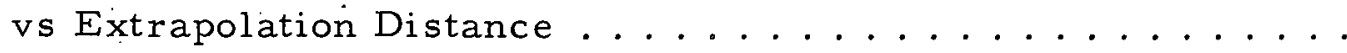

16. Thermal-flux Patterns in Control-rod Region for Cold and Hot

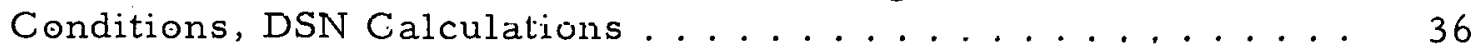

17. Flow-rod Patterns in Boiling Fuel Assembly.......... 41

18. Calculational Cell Model for a Single Boiling Fuel Assembly . . 42

19. Thermal Flux Patterns from PDQ Cell Problems........ 43

20. Cell Types in"12-flow-rod Boiler Assembly .......... 49

21. Calculational Model for Boiler Fuel-rod Cell Calculation . . . 49

22. Calculational Model for Superheater Fuel-element Cell

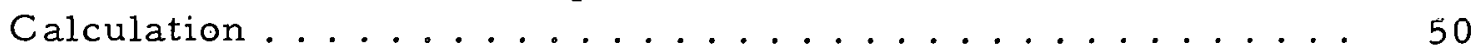

23. Sixteen-680-g-superheater-fuel-assembly Array, Minimum

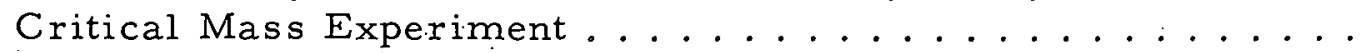




\section{LIST OF FIGURES}

N॰. Title

$\underline{\text { Page }}$

24. Minimum Critical Slab with Boiling Fuel, 12 Flow Rods per Assembly . . . . . . . . . . . . . . . . .

25. PDQ-3 Calculational Model for 16-680-g-Superheater-Assembly Array. . . . . . . . . . . . . . . . .

26. PDQ-3 Calculational Model for 12-flow-rod-boiler Minimum Critical Slab....................... 54

27. PDQ Model for Core PSH-1 . . . . . . . . . . . . 55

28. Calculated Fractional Decrease in Control-rod Worth as a Function of Boric Acid Concentration, Core PSH-1. . . . . . .

29. Nine-control-rod Bank, Calculated Differential Worth, Core PSH-1.......................61

30. Comparison of Experimental and Calculated Changes in Reactivity ........................62

31. Temperature Coefficient, Core PSH-1 . . . . . . . . . 64

32. Fine-power Distribution, Core B-1B ........... 65

33. Final Normalized Fine-power Map, Core CSH-1 . . . . . . . 66

34. Normalized Boiler-region Fine-flux Map, Core PSH-1 . . . . 67

35. Normalized Superheater-region Fine-flux Maf . . . . . . . . 68

36. Fine-flux Traverse through a Boiling Assembly with Various Metal-to-Water Ratios ...................

37. Axial Neutron-flux Distributions at Power, Core Position 43, Core PSH-1A. . . . . . . . . . . . . . . . 71

38. Cadmium-ratio Distributions at $5 \mathrm{MWt}$, Cores PSH- $1 \mathrm{~A}$ and $\mathrm{C}$. . 73

39. Cadmium-ratio Distributions at $15 \mathrm{MWt}$, Cores PSH-1 A and $\mathrm{C}$.

40. Cross Section of Exponential Assembly . . . . . . . . . . 80

41. Exponential Experiment, Center-line Flux Plot ........ 82 


\section{LIST OF TABLES}

No.

Title

Page

I. Summary of BORAX-V Design Characteristics ....... Il

II. Comparison of Core Characteristics with 49 and 100 Fuel Rods per Assembly....................... 12

III. Comparison of Methods Used for Obtaining Homogenized Constants for Static Reactivity Calculations ......... 17

IV. Results of Criticality Calculations. . . . . . . . . . 27

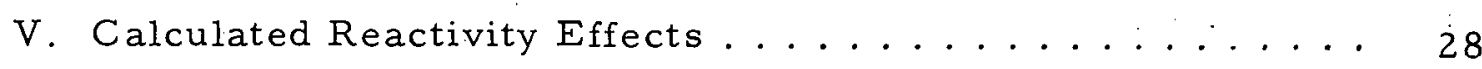

VI. Control-rod-worth Calculations, Values of $k_{\text {eff }}$ for Typical

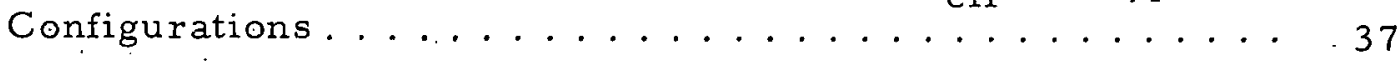

VII. Eigenvalue's of Three-group PDQ Control-cell Problems. . 37

VIII. Thermal Flux Ratios of Nonfuel-to-fuel Regions; Two-

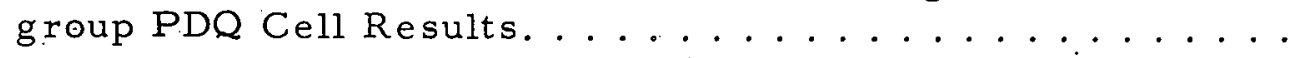

IX. Calculated $k_{\text {eff }}$ for Representative Flow-rod Geometries and Comparative Reactivity Effects, Three-group RE-122

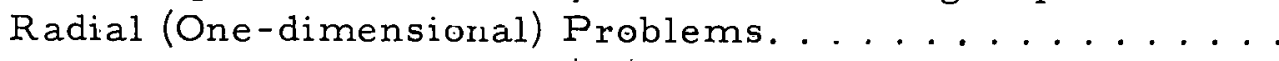

$\mathrm{X}$. Comparison of MUFT Constants for Type 304 Stainless Steel with GAM-I Constants ............... 46

XI. Comparison of Calculation and Experiment, Minimum

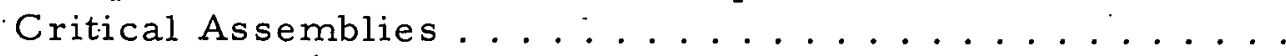

XII. Results of PDQ Problems on Core PSH-1 . . . . . . . . 56

XIII. Results of PDQ Problems on Core B-1D.......... 56

XIV. Calculated Control-rod Worth, Core B-1D ........ 57

XV. Calculated $k_{\text {eff }}$ as a Function of Control-rod Position for Various Boric Acid Concentrations, Core PSH-1 ...... 60

XVI. Effect of Flow Rods on Power Distribution within Boiling

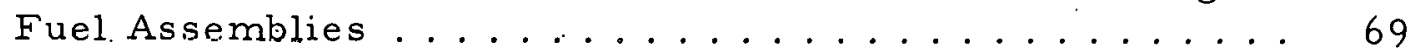

XVII. Experimental Axial Bucklings............... 72

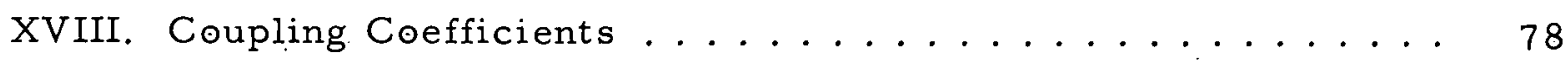


THIS PAGE

WAS INTENTIONALLY

LEFT BLANK 


\section{BORAX-V NEUTRONICS}

by

J. I. Hagen and R. W. Goin

\section{INTRODUCTION}

BORAX $-V$ was designed and constructed as the result of a joint conception by personnel of the Idaho Division and the Reactor Engineering Division of Argonne National Laboratory. The primary objective of the program was to examine the feasibility and characteristics of a boilingwater reactor having an integral or coupled subcritical superheating section. The original plan called for a rather extensive program of study on the general aspects of boiling-water reactor stability involving such factors as variable metal-to-water ratios, forced and natural convection, etc. ${ }^{1}$ Only part of this has been accomplished within the allotted time.

A minimum-sized critical assembly consisting of boiling fuel assemblies was achieved on February 9, 1962, and operation with varied core configurations was continued to August 1964. The BORAX-V plant is fully described in Ref. 2 and will not be repeated here.

While many of the general features of the system appear as the result of previous work in the BORAX series, several other considerations were recognized in arriving at the reference design and may be summarized as follows:

a. The facility was to be low in cost, utilizing existing structures as far as possible.

b. A maximum degree of flexibility was desired. This included provision for achieving a variable metal-to-water ratio, extensive use of in-core instrumentation, adaptability for differing superheater designs, provision for forced and natural convection, etc.

c. A high-power density boiler was desired for examining instabilities in the higher power regions.

Four principal core configurations were contemplated: (1) an allboiling core, (2) a boiling core with a superheating section in the center, (3) a boiling core with superheating elements along the perimeter, and. (4) a core with an intermediate superheating zone, i.e., a square annulus with boiling regions inside and outside. An early decision was made to 
eliminate the last core configuration because of the additional expense and mechanical complications. The entire core included a volume roughly $34 \times 34 \times 24$ in. high. Figure 1 illustrates diagrammatically the superheater core geometries that were actually constructed. The core is further 'subdivided into 60 assemblies ( $4 \times 4$ in.) and nine control rods.
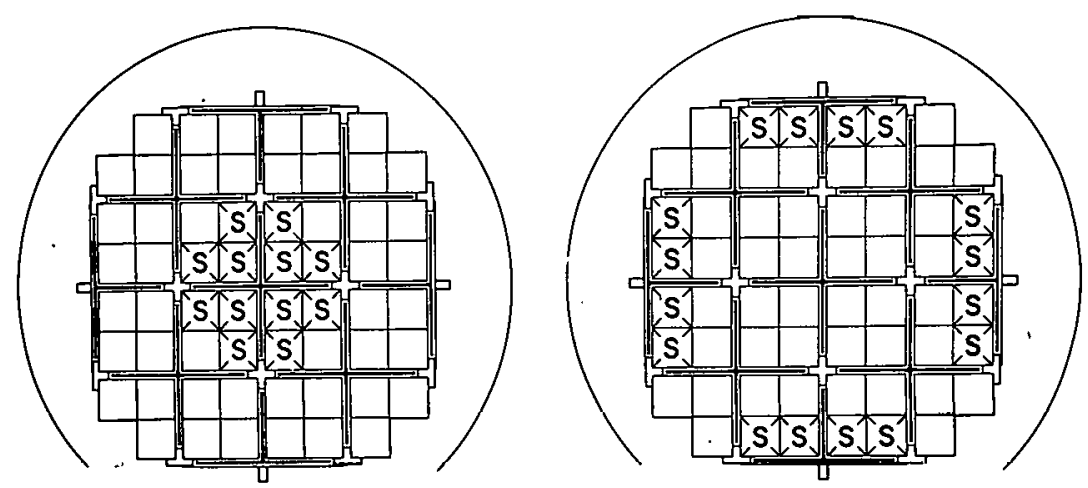

ID-103-3304

Fig. 1. Superheating Cores.

An integral superheater, depending on thermal fissioning, is characterized by special problems of operation. From the reactivity standpoint, attention must be given to flooding the steam spaces, as necessitated in the BORAX design, for shutdown and decay heat removal. With the relatively. small, leaky core of BORAX, this becomes an important point. This and other questions of reactivity effects entering into the design are treated in Section III. The results of more detailed calculations are also given in Section III, the experimental findings are surveyed-in Section IV, and additional topics are covered in Section V.

Many details of the earlier work have been lost, partly as a result of changing personnel and partly due to normal attrition. It is felt, however, that as much of the record as can be assembled should be preserved in the form of this report; and while much of the original work and methods used are now obsolete, they are listed to make the record complete.

The characteristics sought in the design and other miscellaneous plant data influencing the neutronic calculations àre listed in Table I.

Experimental operations were conducted on four distinct cores, classified as B-1, B-2, CSH-1, and PSH-1. The B-1 all-boiler core was assemblied with four variants distinguished as B-lA to - ID, and was in all cases composed of 49-fuel-rod boiler assemblies. Because of a hightemperature reactivity defect, power operation was not conducted with the $\mathrm{B}-1$ core. The B-2, also an all-boiler core, was operated at $22 \mathrm{MWt}$ maximum power. In the B-2 core, four fuel rods were removed from the central region of each fuel assembly, and water-filled rods were installed in their places. The CSH-1 core contained the central superheater and 
utilized eight water-filled rods with 41 fuel rods per boiler assembly. Because of welding failures in the superheater elements, operation was discontinued early in the experimental program, although sustained operation at $15 \mathrm{MWt}$ had been achieved. The PSH-1, or peripheral superheating core, performed very well with a maximum power in excess of 20 MWt. This core used 12 water-filled rods with 37 fuel rods per boiling assembly. Reactivity was depressed in all cores, as needed, by the use of boron-stainless steel rods.

TABLE I. Summary of BORAX-V Design Characteristics

Reactor reference design power

Core with superheater

Boiling region

Superheater

Steam pressure

Saturated-steam temperature

Superheated-steam temperature (reactor exit)

Average power density

Boiler

Superheater

Maximum fuel temperature

Superheater, fuel-plate center

Superheater, fuel-plate surface

Boiler fuel, center of rod

Boiler fuel, surface of rod

Control rods (driven from below)

Absorber material

Cladding

Follower
$20 \mathrm{MWt}$, nominal

16.6 MWt, nominal

3.4.MWt, nominal

$600 \mathrm{psig}$

$489^{\circ} \mathrm{F}$

$850^{\circ} \mathrm{F}$

$95 \mathrm{~kW} /$ liter

$80 \mathrm{~kW} /$ litèr

$1125^{\circ} \mathrm{F}$

$1110^{\circ} \mathrm{F}$

$3100^{\circ} \mathrm{F}$

$515^{\circ} \mathrm{F}$

Boral, $50 \mathrm{w} / \mathrm{OB}_{4} \mathrm{C}$

Type 304 stainless steel X-800l aluminum 


\section{DEVELOPMENT OF FUEL GEOMETRY}

\section{A. Boiling Core}

Enriched $\mathrm{UO}_{2}$ pellets in tubular metallic sheaths were selected for boiler fuel. These were designed to be supported in a twist-lock fashion for easy removal. The original design, with a goal of high power density, had envisaged a small fuel rod of 0.26 -in. diam. Close packing on 3/8-in. centers would make an assembly of 100 rods. Aluminum cladding 0.015 in. thick was planned, and $\mathrm{UO}_{2}$ pellet size was set at 0.230 -in. diam. The $\mathrm{UO}_{2}$ density was to be 0.91 of theoretical maximum.

Subsequent considerations led to a considerable increase in the burnout flux limit that can be ascribed to a larger rod. The ultimate choice thus became forty-nine. 3/8-in.-diam rods per assembly (0.5-in. lattice spacing). This consideration is fully described in Ref. 3. The cladding was also changed from aluminum to Type 304 stainless steel. Other more or less obvious factors favored the larger rod: (1) simplified fuel handling, (2) simplified fabrication, and (3) reduced cladding material.

A summary comparison of neutronic calculations for the two cases is presented in Table II.

TABLE II. Comparison of Core Characteristics with 49. and 100 Fuel Rods per Assembly

\begin{tabular}{|c|c|c|}
\hline . & $\begin{array}{l}100-\operatorname{rod} \\
\text { Asseribly }\end{array}$ & $\begin{array}{l}\text { 49-rod } \\
\text { Assentibly }\end{array}$ \\
\hline Cladding Material: & Aluminum & Stainless Steel \\
\hline $\begin{array}{l}\text { Calculated minimum critical loading } \\
\text { at power }\end{array}$ & $\cdot$ & \\
\hline $\mathrm{U}^{235}$ per rod, g & 5.7 & 13.3 \\
\hline Total $\mathrm{U}^{235}, \mathrm{~kg}$ & 34.2 & 38.2 \\
\hline Percent steam voids assumed & 17.5 & 15.0 \\
\hline $\begin{array}{l}\text { Water-to- } \mathrm{UO}_{2} \text { volume ratio, based } \\
\text { on a rod cell }\end{array}$ & 3.36 & 2.26 \\
\hline
\end{tabular}

Disadvantage factors are compared in Fig. 2. These were calculated by the method described in Section III-B. The final fuel-rod design detail is shown in Fig. 3. 


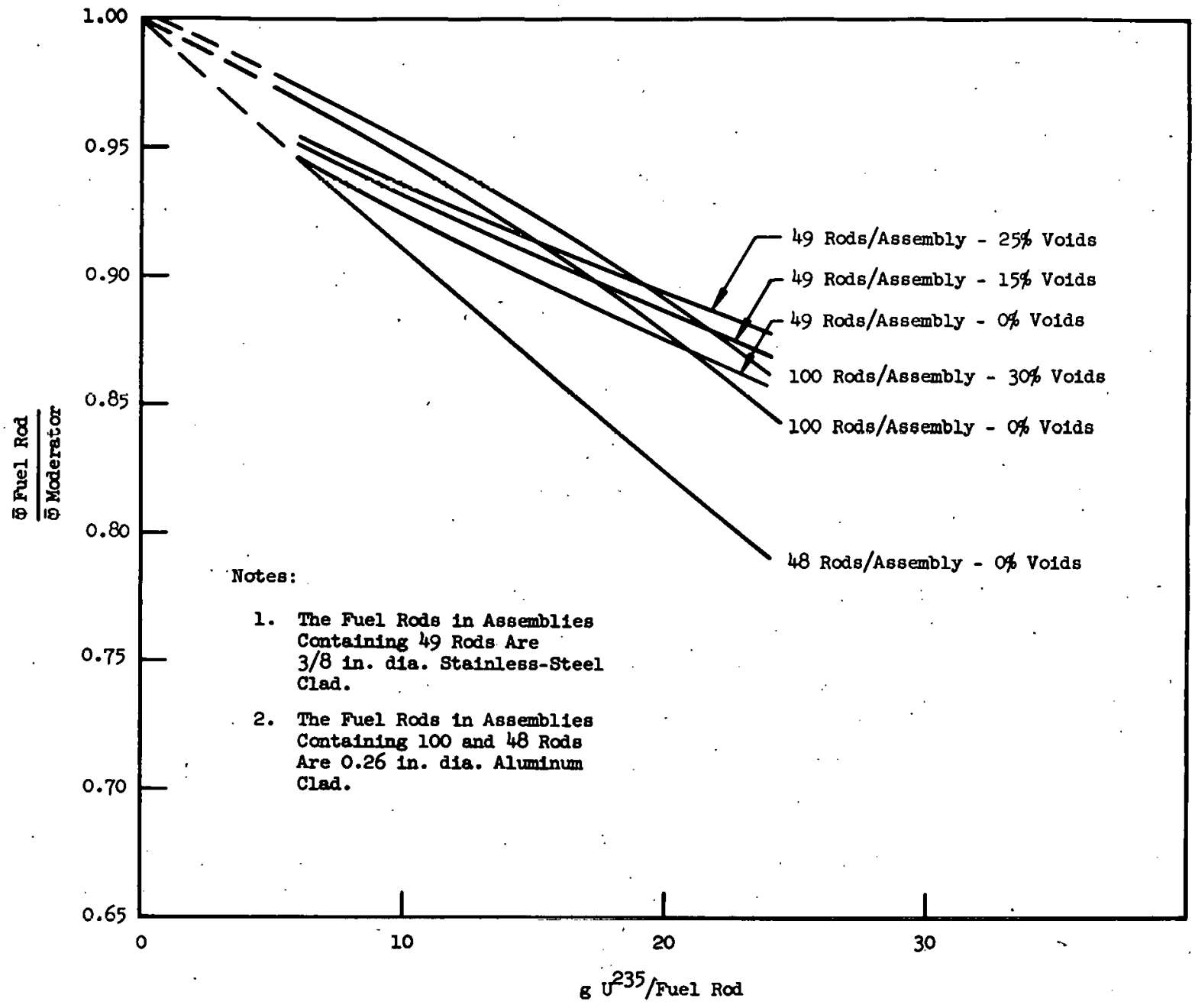

ID-103-A3506

Fig. 2. A Comparison of Disadvantage Factors 


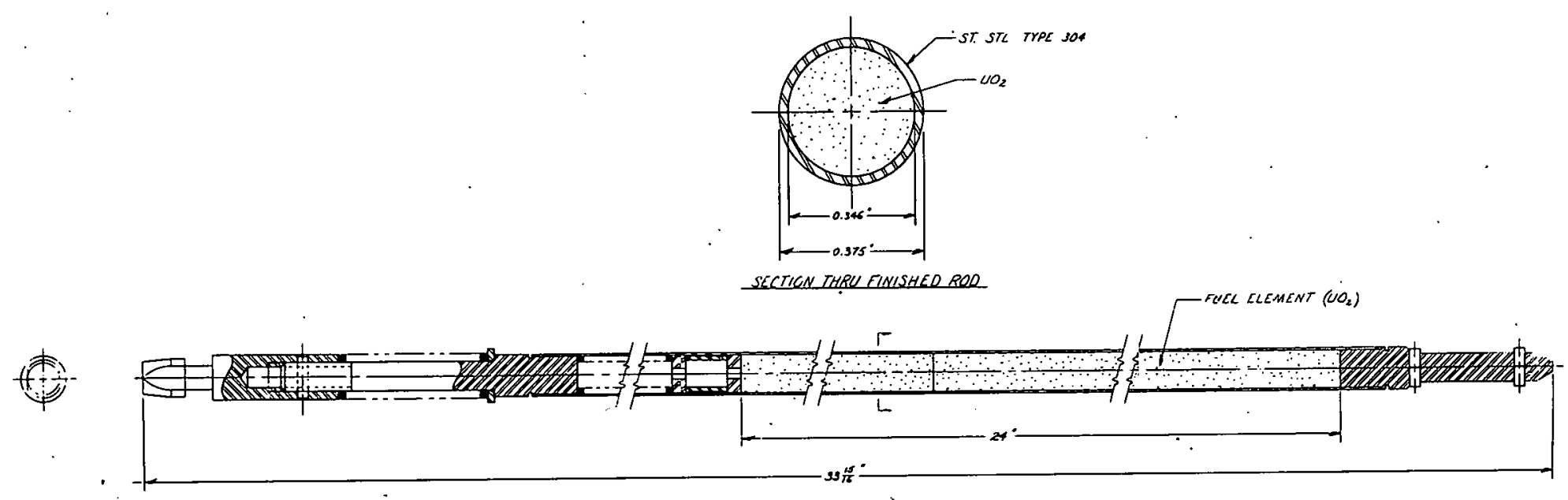

ID-103-A 3322

Fig. 3. Boiling Fuel Rod 
The use of 3/8-in.-diam stainless-steel rods containing $2 \mathrm{w} / 0$ natural boron was envisaged as a means of controlling overall and local reactivity effects as such need might arise when one boiler enrichment is used for all core configurations. The plan, as adopted, entailed the removal of fuel rods in selected positions and replacing them with poison rods. Rod worth in cases in which the withdrawal of a single rod could make the reactor critical was satisfactorily depressed by placing one or more such poison rods near the control rod.

\section{B. Superheater}

The superheater section was originally visualized as a tubular structure. Considerable effort was expended in assessing this and other variants. The use of a solid moderator such as zirconium hydride was also considered, but because of the lack of complete knowledge of moderating characteristics and/or structural stability at high temperatures, this was ruled out. A flat-plate cermet with a water moderator was finally chosen, the fuel therein being fully enriched.

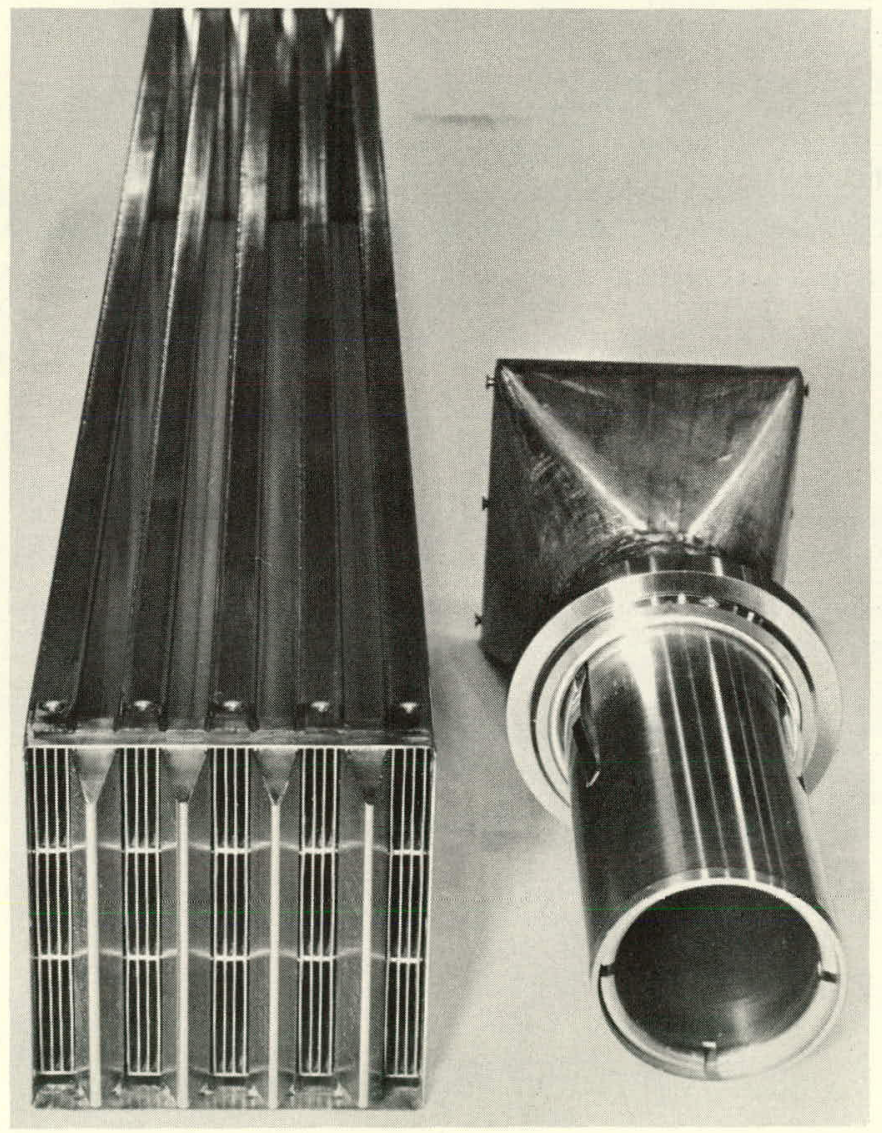

ID $-103-3776$

Fig. 4. Superheater Fuel Assembly
The first concept of a water-moderated design consisted of four elements per assembly, each element consisting of 16 plates (0.10-in. cermet thickness, 0.010-in. cladding thickness, with 0.047-in. steam gaps). Reference 3 describes this earlier design, together with the first version of the final design.

Power-distribution characteristics and considerations of cost of fabrication led to the final design, shown in Fig. 4. The use of less stainless steel in the final design results in better neutron economy. The same general pattern was used for both central and peripheral superheating assemblies, differing only in the $\mathrm{U}^{235}$ content.

The many special problems encountered and methods employed in the fabrication of the superheater fuel have been reported by Kramer and Bean, ${ }^{4}$ and work accomplished by others in this and related fields is summarized in Ref. 5. 


\section{NEUTRONIC CALCULATIONS}

A. General

During the BORAX-V project, three sets of criticality calculations were preformed. In all cases, standard computer production codes were employed primarily, the principal difference being in the methods used for homogenization and in the cross-section codes used. Since this reactor was not intended for long-time operation, problems such as burnup received little attention. Of greater importance were the factors of safety, the prediction of operational characteristics, and, as is always the case, the effort to find what is necessary to obtain agreement with experiment. It is not possible in much of the experimental work, however, to find points at which experiment and theory can be compared satisfactorily. The reason for this is that frequent changes were necessitated, such as positioning boron poison rods in a particular pattern to prohibit criticality on the withdrawal of a single control rod or the placement of an oscillator unit within the core, etc. The design work was not guided by a separate critical facility, but certain index points were obtained from critical experiments ${ }^{6,7}$ made with BORAX-V fuel at the ZPR-7 facility at Argonne, Illinois, and an exponential experiment ${ }^{8}$ was performed with the aid of the TREAT facility.

In addition to static-reactivity calculations, other studies were made on control-rod effects, perturbations due to boron poison rods, fluxflattening methods, and several other items. These are outlined in the text.

To facilitate the discussion, the calculational procedures employed in obtaining constants can be designated as follows:

1. In the original design calculations, the $\mathrm{UO}_{2}$ enrichment of the boiler was determined, as well as the required fuel distribution to achieve the desired power sharing between boiler and superheater. MUFT ${ }^{9}$ and SOFOCATE ${ }^{10}$ constants were used.

2. The same computer codes were used, but emphasis was on optimization of flow-rod arrangements as a guide for operations.

3. Calculations were made with $\mathrm{GAM}^{11}$ and TEMPEST ${ }^{12}$ constants designed specifically to check experimental methods and results.

Table III compares the procedural differences employed in the three cases. 
TABLE III. Comparison of Methods Used for Obtaining Homogenized Constants for Static Reactivity Calculations

\begin{tabular}{|c|c|c|}
\hline METHOD I (Design Calculations) & METHOD II & METHOD III \\
\hline Section III-B & Section III-C & Section. III-D \\
\hline $\begin{array}{l}\text { Calculate overall homogenized atom } \\
\text { densities, boiler and superheater separately. }\end{array}$ & $\begin{array}{l}\text { Calculate number of densities of } \\
\text { subregions of a control cell. }\end{array}$ & $\begin{array}{l}\text { Calculate } \mathrm{Ni} \text { for subregions and for } \\
\text { homogenized regions. }\end{array}$ \\
\hline \multirow{3}{*}{$\begin{array}{l}\text { Calculate thermal disadvantage factors. } \\
\text { Adjust proportionate part of water and } \\
\text { fuel-rod constituent } \mathrm{Ni} \text { for SOFOCATE } \\
\text { constants in accordance with fuel-rod } \\
\text { disadvantage factors. }\end{array}$} & \multirow{2}{*}{$\begin{array}{l}\text { Adjust } \mathrm{N}_{\mathrm{i}} \text { of fuel region with } \\
\text { disadvantage factors obtained } \\
\text { in Method } \mathrm{I} \text {. } \\
\text { Calculate MUFT L-factors for fuel region. }\end{array}$} & \multirow{2}{*}{$\begin{array}{l}\text { 1. Thermal constants for various tempera- } \\
\text { tures and boric acid concentrations. } \\
\text { Obtain thermal spectrum for homoge- } \\
\text { nized region--TEMPEST. }\end{array}$} \\
\hline & & \\
\hline & $\begin{array}{l}\text { Run MUFT and SOFOCATE problems for } \\
2-4 \text { group constants. }\end{array}$ & $\begin{array}{l}\text { Average cell-subregion constants over } \\
\text { homogenized spectrum--TEMPEST. }\end{array}$ \\
\hline \multirow{6}{*}{ Calculate L-factor for MUFT input. } & \multirow{2}{*}{$\begin{array}{l}\text { Run PDQ cell problems to obtain an } \\
\text { "assembly disadvantage factor," } d_{a} \text {. } \\
\text { Adjust overall homogenized } \mathrm{Ni} \text { with } \mathrm{d}_{\mathrm{a}} \text {. }\end{array}$} & $\begin{array}{l}\text { Obtain disadvantage factors from cell } \\
\text { calculations (pin or plate)--S4 or DP-1. }\end{array}$ \\
\hline & & $\begin{array}{l}\text { Obtain homogenized subregion con- } \\
\text { stants by flux and volume weighting } \\
\text { subregion constants. }\end{array}$ \\
\hline & \multirow{4}{*}{$\begin{array}{l}\text { Rerun MUFT and SOFOCATE with } \\
\text { adjusted } \mathrm{N}_{i} \text { to obtain new homoge- } \\
\text { nized constants. }\end{array}$} & $\begin{array}{l}\text { 2. Fast constants for various temperatures } \\
\text { and boric acid concentrations. }\end{array}$ \\
\hline & & $\begin{array}{l}\text { Calculate Dancoff-Ginsberg } \\
\text { shadowing factor. }\end{array}$ \\
\hline & & $\begin{array}{l}\text { Obtain fast spectrum for homogenized } \\
\text { region--GAM. }\end{array}$ \\
\hline & & $\begin{array}{l}\text { Average subregion constants over } \\
\text { homogenized spectrum--GAM. }\end{array}$ \\
\hline
\end{tabular}

B. Design Calculations

Figures 5 and 6 illustrate the configurations from which atom densities were calculated for the boiling and superheater section, respectively. Since the relative boiler-superheater loadings were unknown at this phase, it was decided that constants should be obtained for a range of enrichments and conditions. An arbitrary set of $\mathrm{U}^{235}$ contents per rod was assumed; disadvantage factors were calculated by using Maxwellian-averaged thermal constants; and a series of SOFOCATE problems was run for thermal constants for the boiler. "L," or self-shielding, factors were supplied for companion MUFT-IV problems. SNG slab problems gave an estimation of the superheater disadvantage factor, but the superheater fuel was to be fully enriched and the L-factor was taken as unity. formulas:

The atom densities (uncorrected) are represented by the following

$$
\begin{aligned}
& \text { Boiling Core (forty-nine } 3 / 8 \text {-in.-diam fuel rods per as embly) } \\
& \mathrm{N}_{\mathrm{H}}=(0.28987)(\rho)(1-\mathrm{Z})+(0.004949) \rho, \\
& \mathrm{N}_{\mathrm{O}}=\mathrm{N}_{\mathrm{H}} / 2+2\left(\mathrm{~N}_{\mathrm{U}^{235}}+\mathrm{N}_{\mathrm{U}^{238}}\right), \\
& \mathrm{N}_{\mathrm{Fe}}=2.54121 \times 10^{-3},
\end{aligned}
$$




$$
\begin{aligned}
\mathrm{N}_{\mathrm{Ni}} & =4.6949 \times 10^{-4}, \\
\mathrm{~N}_{\mathrm{Al}} & =1.32561 \times 10^{-2}, \\
\mathrm{~N}_{\mathrm{Cr}} & =6.5338 \times 10^{-4}, \\
\mathrm{~N}_{\mathrm{U}^{235}} & =1.59717 \mathrm{G}_{\mathrm{r}} \times 10^{-5}, \\
\mathrm{~N}_{\mathrm{U}^{238}} & =(1.57932)\left(323.04-\mathrm{G}_{\mathrm{r}}\right) 10^{-5} ;
\end{aligned}
$$

Superheater

$$
\begin{aligned}
\mathrm{N}_{\mathrm{H}}= & 0.027275 \rho+0.015883 \rho^{p} \text {, where } \rho^{1} \text { is zero if not flooded, } \\
& \text { or is equal to } \rho \text { if flooded, } \\
\mathrm{N}_{\mathrm{O}}= & \mathrm{N}_{\mathrm{H}} / 2+L\left(\mathrm{~N}_{\mathrm{U}^{235}}+\mathrm{N}_{\mathrm{U}^{238}}\right), \\
\mathrm{N}_{\mathrm{Fe}}= & 0.0110146-0.86358 \times 10^{-6} \mathrm{~L}, \\
\mathrm{~N}_{\mathrm{Ni}}= & 0.0018189-0.13885 \times 10^{-6} \mathrm{~L} \\
\mathrm{~N}_{\mathrm{Al}}= & 0.010433 \\
\mathrm{~N}_{\mathrm{Cr}}= & 0.0028320-0.22204 \times 10^{-6} \mathrm{~L}, \\
\mathrm{~N}_{\mathrm{U}^{235}}= & 0.32595 \times 10^{-6} \mathrm{~L} \\
\mathrm{~N}_{\mathrm{U}^{238}}= & 0.23479 \times 10^{-7} \mathrm{~L} ;
\end{aligned}
$$

where

$$
\begin{aligned}
G_{r} & =g \text { of } U^{235} \text { per fuel rod, } \\
\rho & =\text { density of water } \\
& =1.000 \text { for cold or room temperature } \\
& =0.793 \text { for hot or } 489^{\circ} \mathrm{F} \text { water },
\end{aligned}
$$

$\mathrm{Z}=$ void fraction due to boiling (applies only to fraction of water adjacent to fuel rods),

and

$$
L=g \text { of } U^{235} \text { per superheater assembly. }
$$



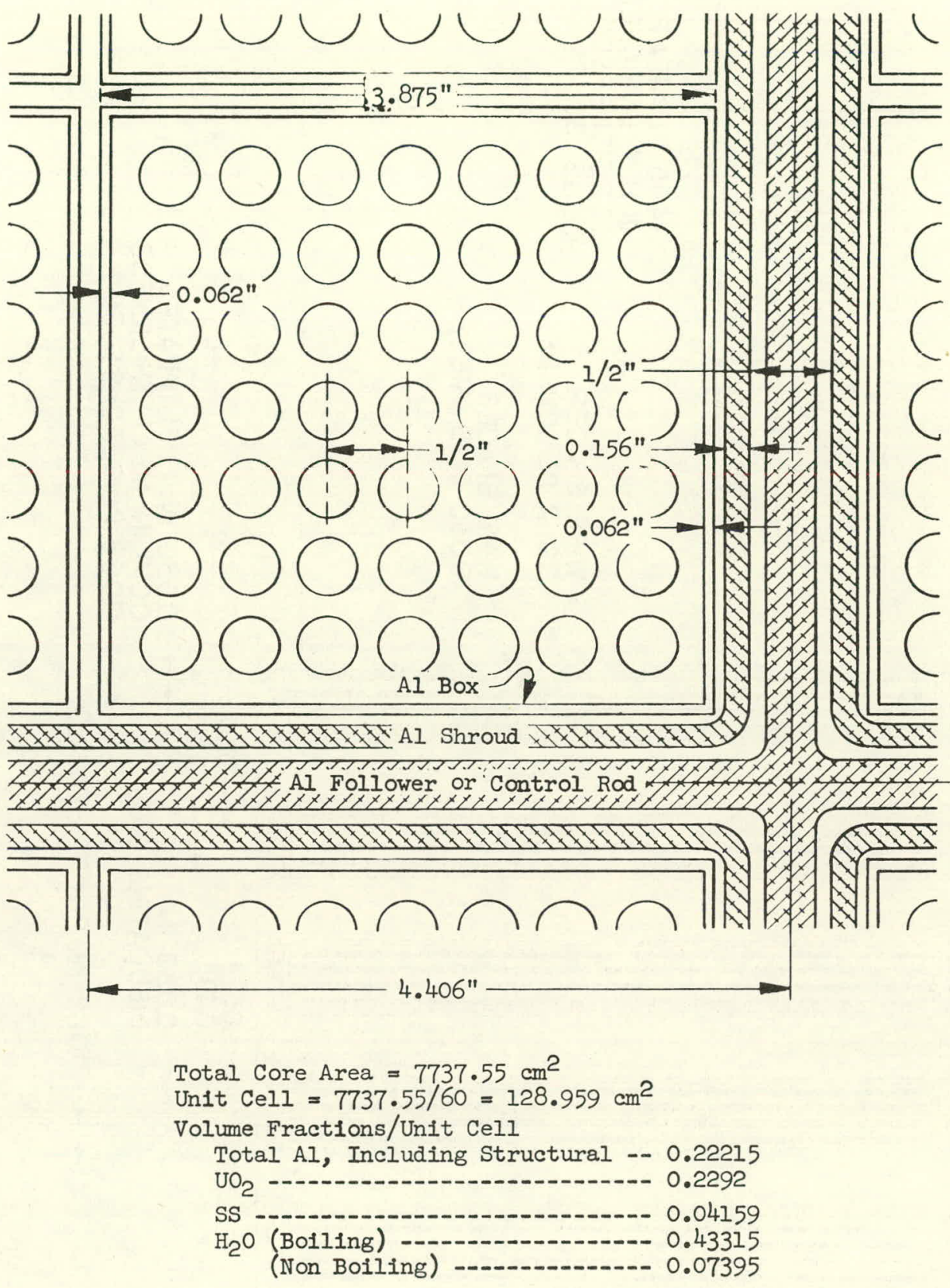

ID-103-A3505

Fig. 5. Diagram for Calculating Atom Densities, Boiling Region 


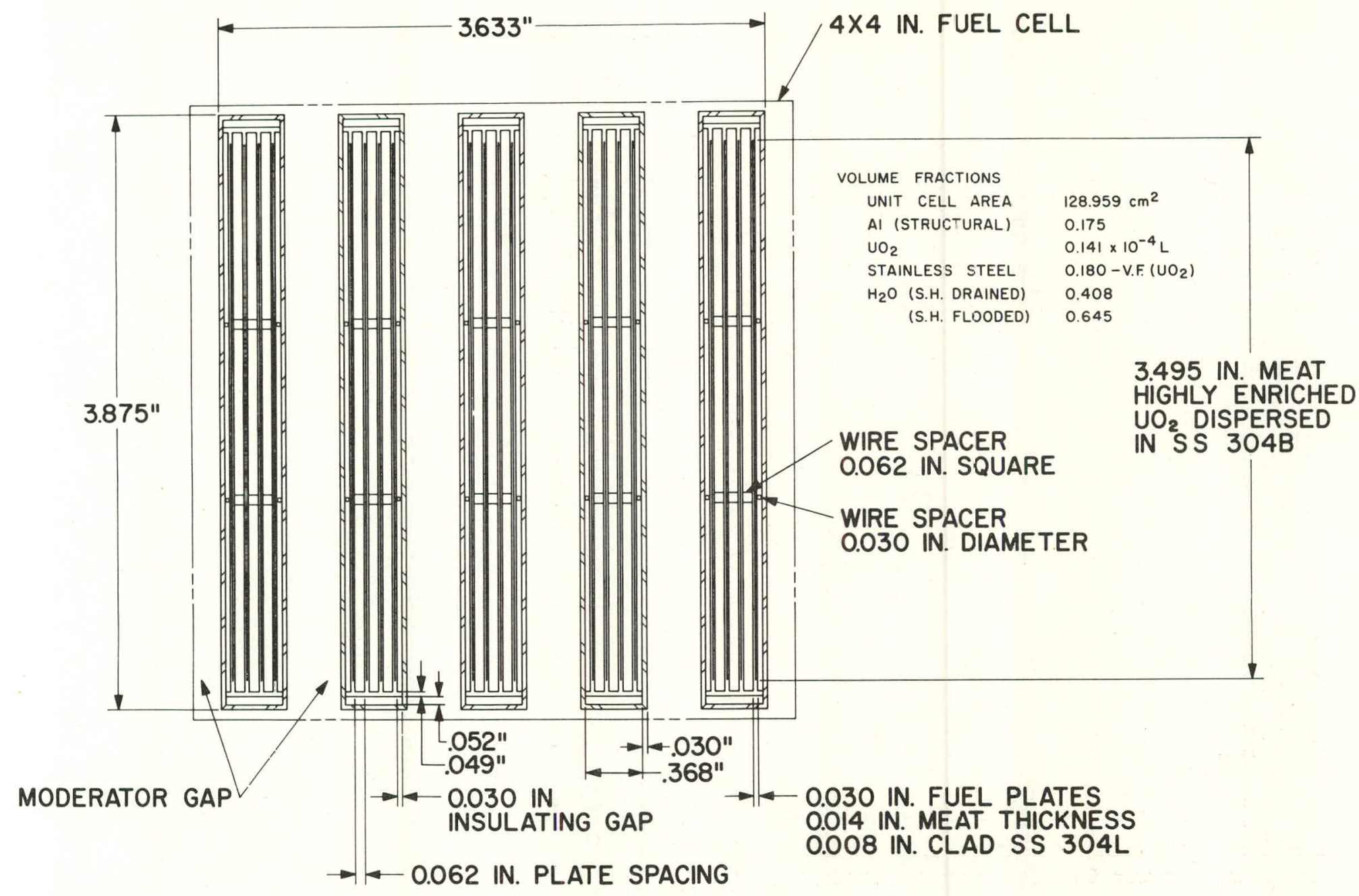

ID-103-A3535

Fig. 6. Atomic Density Calsulation Diagram, Superheater Fuel Assembly 


\section{Disadvantage Factors and Thermal Constants}

The disadvantage factors for the boiling rods were calculated by modification of a method suggested by Copic and Thie. ${ }^{13}$ The method used involves (1) calculation of diffusion-theory flux ratios for the cylinder, (2) transformation of the cylinder to an "equivalent" slab, (3) calculation of $\mathrm{P}_{3}$ and diffusion-theory flux ratios for this slab, and (4) estimation of $\mathrm{P}_{3}$ flux ratios for the original cylinder. This procedure was used because the $\mathrm{P}_{3}$ and SNG codes for cylindrical geometry and Amouyal's method ${ }^{14}$ gave physically unreasonable results in this case. Since this time, however, the problem has been resolved by using an isotropic scattering boundary condition. ${ }^{15}$ The disadvantage factors (DF) calculated for the boiler fuel are displayed graphically in Figs. 7 and 8.

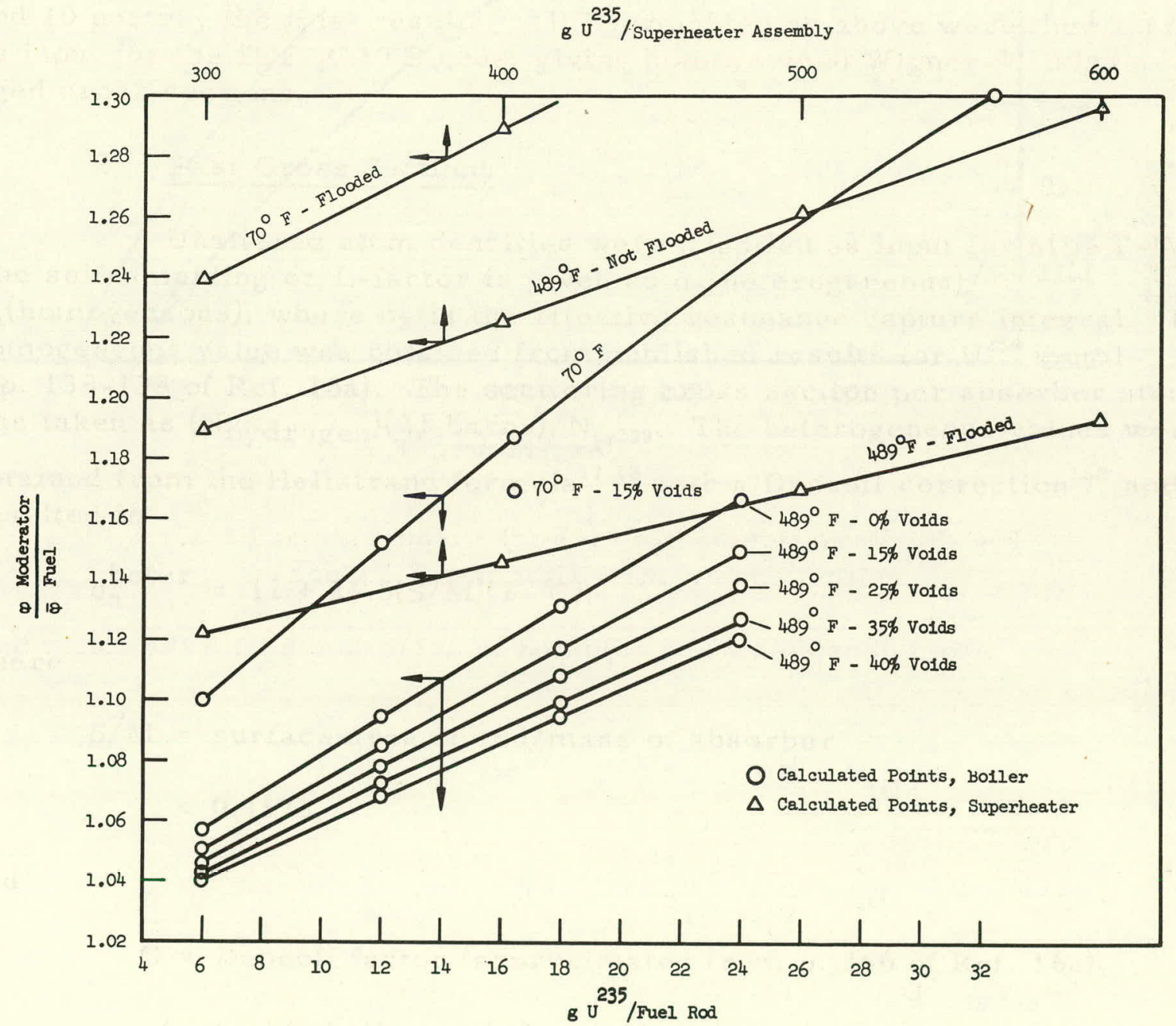

ID-103-A3504

Fig. 7. Calculated Disadvantage Factors 


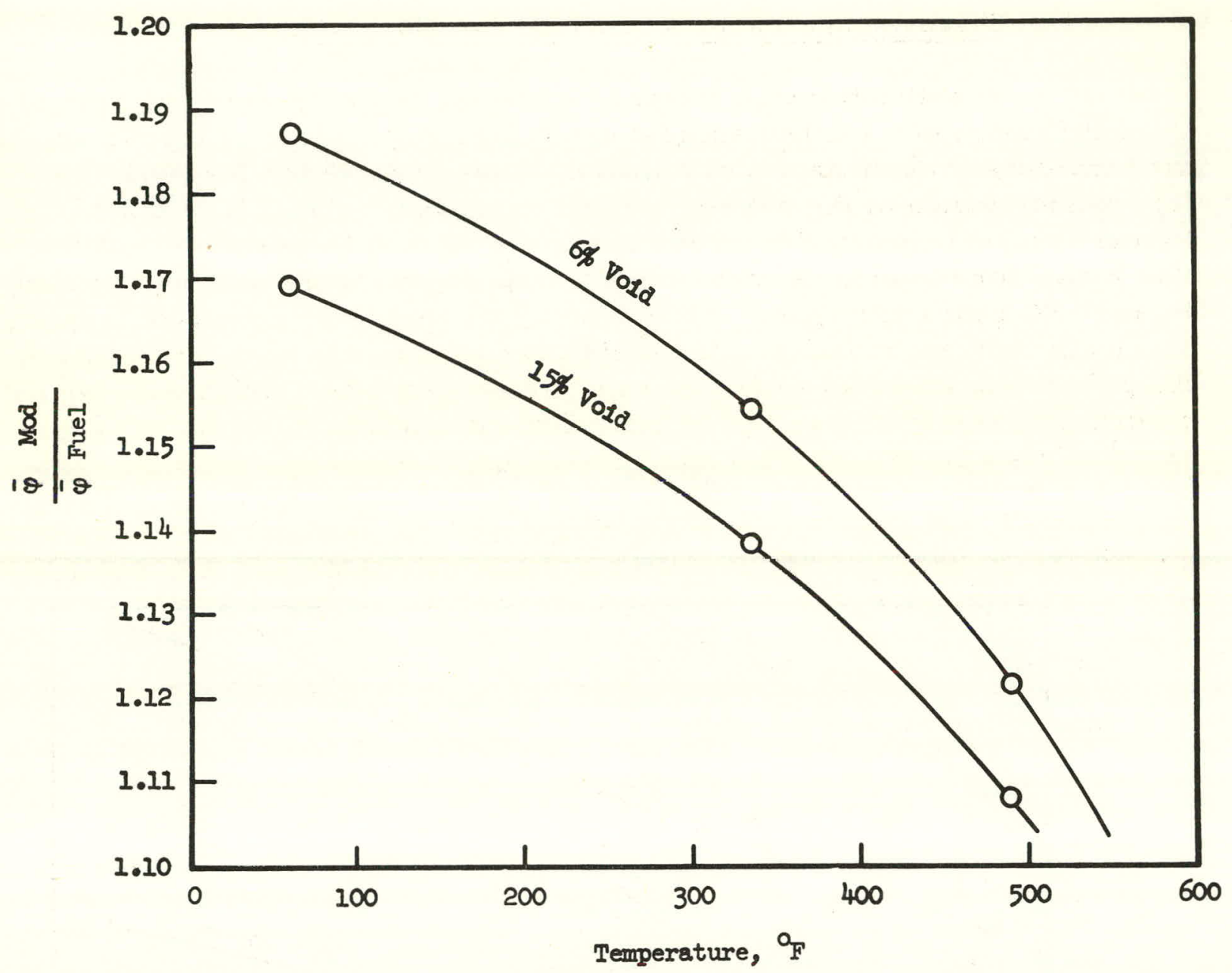

ID-103-A 3514

Fig. 8. Variation of Boiler Fuel Disadvantage Factors with Temperature; Calculated Values

Atom densities were adjusted in accordance with the following rule:

$$
\begin{aligned}
\mathrm{DF} & =\frac{\mathrm{D}_{\mathrm{w}}}{\mathrm{D}_{\mathrm{f}}}>1 \\
\mathrm{D}_{\mathrm{f}} & =\frac{1}{\mathrm{~V}_{\mathrm{f}}+(\mathrm{DF}) \mathrm{V}_{\mathrm{w}}}<1, \\
\mathrm{D}_{\mathrm{W}} \mathrm{V}_{\mathrm{W}}+\mathrm{D}_{\mathrm{f}} \mathrm{V}_{\mathrm{f}} & =1 \\
\mathrm{~N}_{\text {fuel }} \times \mathrm{D}_{\mathrm{f}} & =\mathrm{N}_{\text {fuel }}(\text { effective }), \\
\mathrm{N}_{\text {mod }} \times \mathrm{D}_{\mathrm{w}} & =\mathrm{N}_{\text {mod }}(\text { effective }),
\end{aligned}
$$


where $V_{f}$ and $V_{w}$ are volume fraction of the fuel and moderator, respectively, and $D_{f}$ and $D_{w}$ are proportional to the average flux in the fuel and moderator, respectively. The cladding material was considered as part of the fuel. This would introduce some error, since the reaction rate in stainless steel is underestimated. Also, in the assembly homogenization, the aluminum structure was included with the moderator.

Disadvantage factors for the superheater were obtained by running SNG slab-cell problems. The material within a four-fuel-plate superheater element, including the stainless-steel side plates, was homogenized on a first trial, but later problems considered each plate. The usual zerocurrent condition was as sumed to exist midway in the water gaps between elements. The later problems helped to adjust the loading within the individual fuel plates to effect a slightly flatter power distribution. Figures 9 and 10 portray the final results. All $\mathrm{N}_{\mathrm{i}}$ weighted as above were then entered as input for the SOFOCATE code, giving homogenized Wigner-Wilkins averaged cross sections.

\section{Fast Cross Sections}

Unaltered atom densities were supplied as input for MUFT-IV. The self-shielding or L-factor is given as $\sigma_{a}$ (heterogeneous)/ $\sigma_{a}$ (homogeneous), where $\sigma_{a}$ is the effective resonance capture integral. The homogeneous value was obtained from published results for $\mathrm{U}^{238}$ metal (pp. 138-139 of Ref. 16a). The scattering cross section per absorber atom was taken as ( $\left.\mathrm{N}_{\text {hydrogen }}\right)(21$ barns $) / \mathrm{N}_{U}{ }^{238}$. The heterogeneous values were obtained from the Hellstrand formula ${ }^{17,18}$ with a Dancoff correction ${ }^{16 a}$ and resulted in

$$
\sigma_{a}^{\text {heter }}=11+24.5(\mathrm{~S} / \mathrm{M})(1-\mathrm{C})
$$

where

$$
\begin{aligned}
\mathrm{S} / \mathrm{M} & =\text { surface area of } \mathrm{rod} / \mathrm{mass} \text { of absorber } \\
& =0.4573,
\end{aligned}
$$

and

$$
C=\text { Dancoff factor (approximated from p. } 346 \text { of Ref. 16a). }
$$

In the hot boiler with dry central superheater, a variance of $10 \%$ in the $\mathrm{L}$-factor indicated a difference of about $1 \%$ in $\mathrm{k}_{\text {eff }}$ and $1.7 \%$ in the superheater power fraction. 


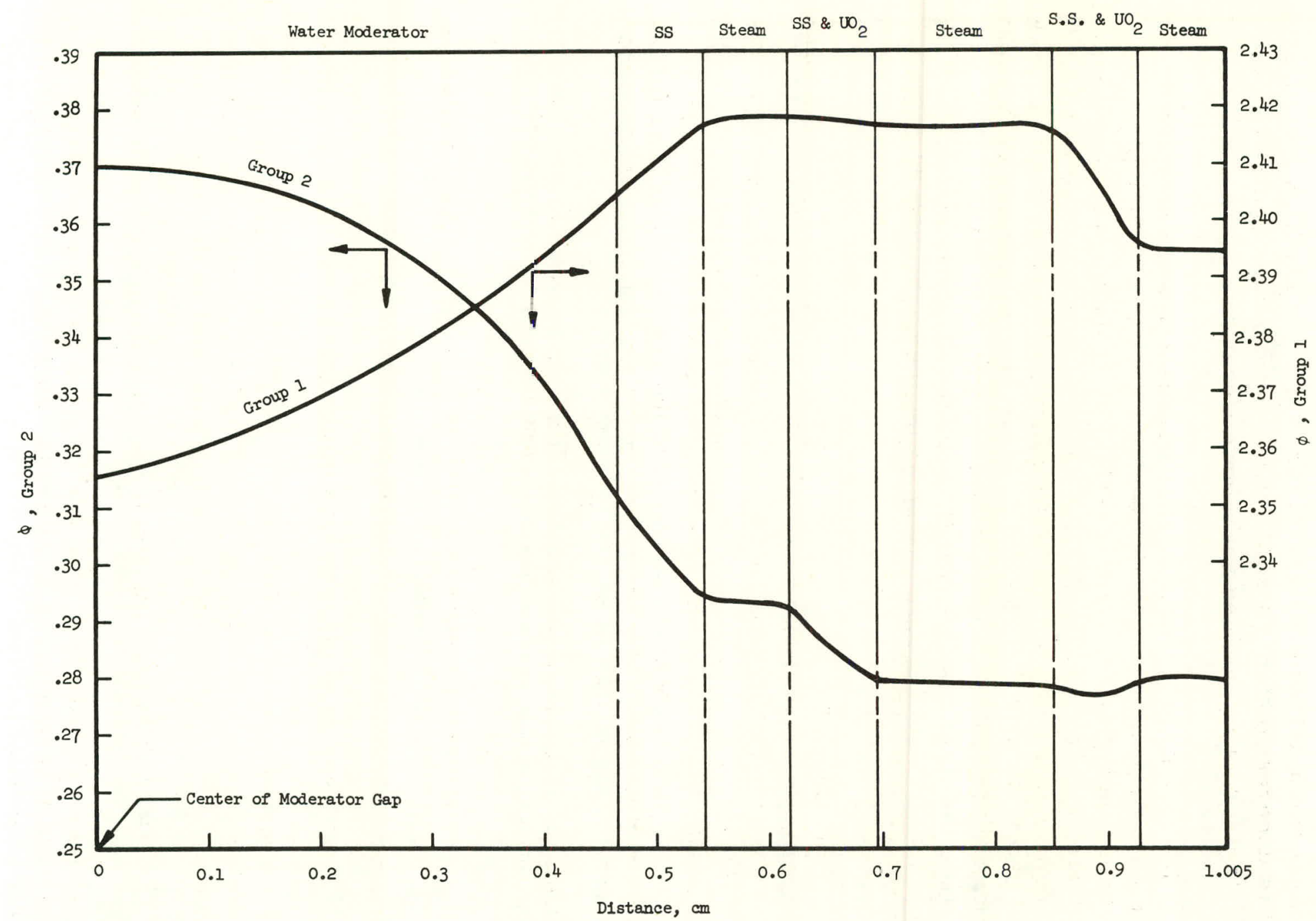

ID-103-A3525

Fig. 9. Fine Flus Structure in Superheater Fuel Element 


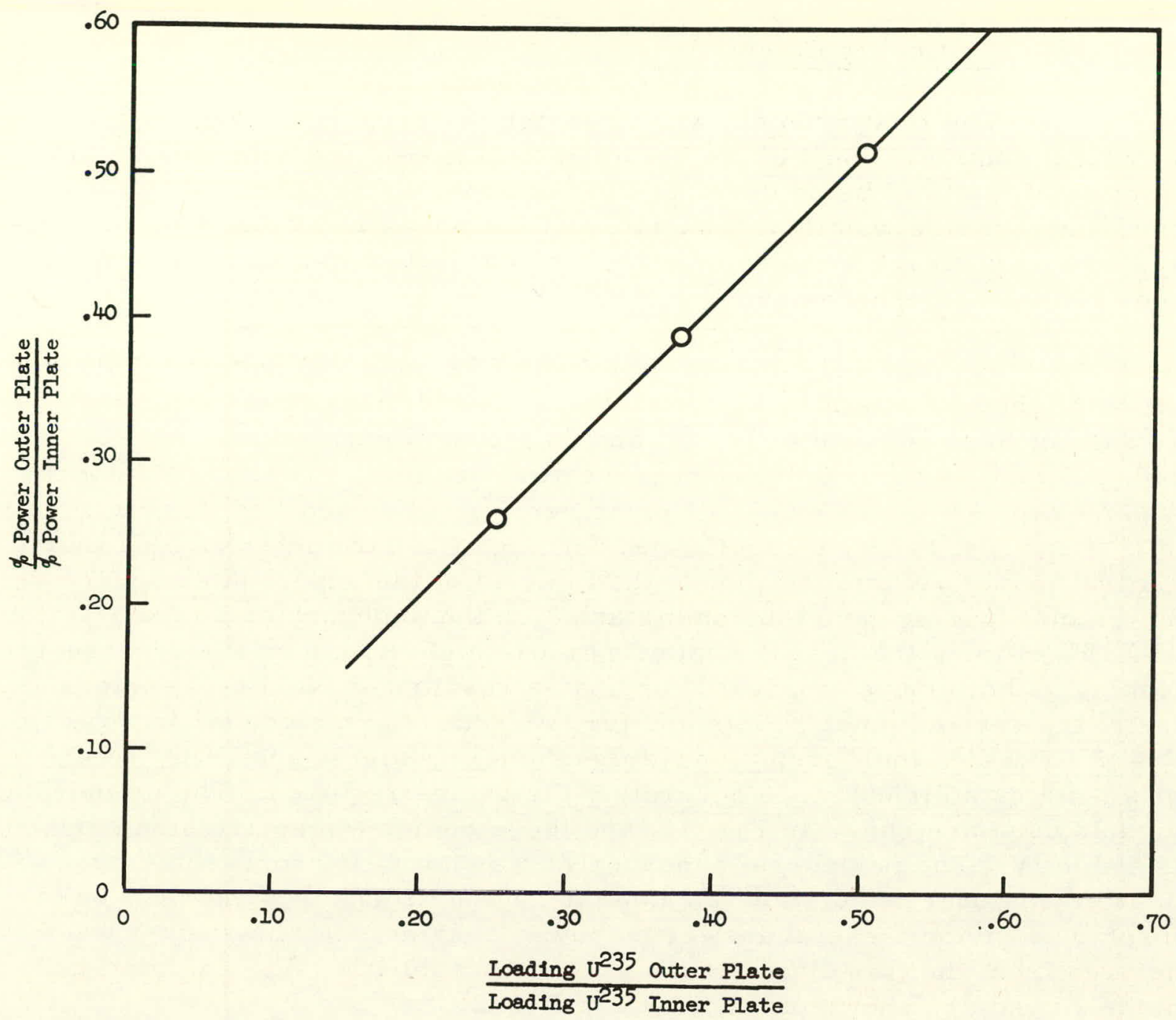

ID-103-A3513

Fi.g. 10. Variation of Power Production in Superheater Fuel Plates as Related to $\mathrm{U}^{235}$ Content

A Doppler correction was attempted, although little information could be found on uranium oxide at that time. Knowledge of an effective fuel temperature as a function of power was also lacking. A linear approximation from data reported on $\mathrm{U}_{3} \mathrm{O}_{8}$ was finally used to make a slight adjustment in the heterogeneous value (p. 681 of Ref. 19). Values of the Doppler correction for $\mathrm{U}^{238}$ metal appear (p. 351 of Ref. 16a) in the form

$$
1 / \mathrm{A} \cdot \mathrm{dA} / \mathrm{dt}=1.425 \times 10^{-4}
$$

(average of four values listed), where $\mathrm{A}$ is given by resonance integraleff $=$ $\mathrm{A}(1+\mu \mathrm{S} / \mathrm{M})$ and $\mathrm{t}$ is in degrees Centigrade. How this could be applied to the present core with uranium oxide was not clear since the Hellstrand formula is of an empirical form and given to represent the oxide case. 


\section{Criticality Calculations}

The first problem was to assign the proper loadings to achieve a critical configuration with an as sumed total power and with a particular fraction of the total being developed in the superheater. An average value of $15 \%$ steam void was thus associated with a power of 20-30 MWt; to achieve an $850^{\circ} \mathrm{F}$ exit steam temperature, $19 \%$ of total power was calculated to be required in the superheater.

A graphical solution appeared to be most convenient. This was accomplished by obtaining $k_{\text {eff }}$ (two-group, one-dimensional calculation) for a range of loadings with $6,12,18$, and $24 \mathrm{~g}$ of $\mathrm{U}^{235}$ per fuel rod and 300 , 400,500 , and $600 \mathrm{~g}$ of $\mathrm{U}^{235}$ per superheater assembly. The RE-122 code $\mathrm{c}^{16 \mathrm{~b}}$ (at this time known as RE-6, a Univac version) was used. Plots of keff vs $g$ of $U^{235}$ per fuel rod with superheater loading as a parameter yielded four critical points. A similar plot of the integral of the superheater source vs boiler fuel loading gave four points at which the superheater power fraction was $19 \%$ of the total. Finally, plotting these eight points on the superheaterloading vs boiler-fuel-loading coordinates resulted in two curves intersecting at the desired point. Plots and further details are given on pp.60-61 of Ref. 2. Further four-group, one-dimensional problems and $\mathrm{PDQ}^{20}(\mathrm{X}-\mathrm{Y})$ problems established more accurately the values required. The cylindrical models used are shown in Fig. 11, and these computations are summarized in Table IV. The peripheral superheater was not well represented by a one-dimensional calculation (an annular region around a cylindrical boiler) ins ofar as giving a useful answer on power sharing, and the answer was derived from the two-dimensional X-Y PDQ problems. The calculational models used are shown on pp.63-6b ot Ket. L.

Since the central superheating configuration designated the largest value of loading for the boiler, this was selected as the basis for the boiling-fuel enrichment. An approximate value of the reactivity required to override fission-product poisons and a small allowance for burnup set this loading finally at $16.2 \mathrm{~g} \mathrm{U}^{235}$ per fuel rod. The central superheating assemblies and the peripheral superheating assemblies were similarly designated to contain $430 \mathrm{~g}$ of $\mathrm{U}^{235}$ and $680 \mathrm{~g}$ of $\mathrm{U}^{235}$ per assembly, respectively. One set of boiling fuel rods with a single enrichment served for all configurations. This value was thus set at $4.95 \mathrm{w} / \mathrm{o} \mathrm{U}^{235}$, and a few rods with twice this enrichment were obtained for experimental purposes.

To examine the possibility of achieving the desired power split at various power conditions and to study the reactivity effects of temperature, voiding, and superheater flooding, additional problems were run. The RE-122 code is designed to iterate on composition to give a critical configuration. In this instance, iteration was made on the three cores to give the volume fraction of a unit absorber in the thermal group to produce a keff of 
savings was $0.00185 \mathrm{~cm}^{-2}$. A value of $0.001889 \pm 0.0000026 \mathrm{~cm}^{-2}$ was measured on the experiment. The axial reflector savings thus determined was $11.32 \pm 0.05 \mathrm{~cm}$.

A minimum critical array was first achieved with 14 boiling fuel assemblies in a $4 \times 4$ array with opposite corner assemblies missing. ${ }^{28}$ On the basis of RE-6, one-dimensional, cylindrical calculations, 11 assemblies had been predicted.

It is difficult to make many direct comparisons of calculation with experiment. It is desirable to obtain points at which criticality is well defined and the geometry is simple enough to be comparable with the calculation. A total available excess reactivity of $12 \%$ was obtained for the first B-1 core. ${ }^{28}$ The method of finding this depended on integrating the differential rod worths vs rod height, the differential rod worths being obtained by the customary method of bumping control rods a small amount to put the reactor on a period. Successively higher rod positions were obtained by incremental additions of boric acid.

It may be suspected that the use of boric acid would underestimate the available excess reactivity. If all other factors such as the source effect on the asymptotic period and the available excess reactivity of $12 \%$ obtained for the full $49 \mathrm{rod} /$ assembly core are assumed correct, the following comparison is typical of what is often done:

The RE-6 problem for the cold clean core gave a keff of 1.229 . The core contained 36 boron-stainless steel poison rods. An approximation of the worth of these rods from Fig. 12 (36 poison rods are equivalent to 0.6 rod per assembly) gives about $-5.5 \% \rho$. A $k_{\text {eff }}$ of 1.229 is equivalent to a $\rho$ of $18.6 \%$, or an available excess reactivity of $\sim 12.1 \%$.

A measurement of poison-rod worth in the B-lA core, in which the rod was located about $7.5 \mathrm{in}$. from the center of the core, gave a reactivity worth of $-0.14 \%$. From Fig. 12, the worth of one rod per assembly is $-9.0 \%$, or $1 / 60$ of this (assuming linearity) is $-0.15 \%$.

Again, a rough comparison may be made with RE-6 problem 580013 (Table V) where an addition to the thermal $\Sigma_{\mathrm{a}}$ of an amount, 0.0355 , resulted in a keff of unity. Approximately $20 \mathrm{~g}$ of boric acid per gallon of water would permit complete withdrawal of the control rods from core B-1A. Using the Maxwellian-averaged value from the SOFOCATE second deck, ${ }^{25}$ 
a value of $\sigma_{a}=3556$ barns is obtained for $\mathrm{B}^{10}$. With a water fraction of 0.442 , and allowing $3785.43 \mathrm{~cm}^{3} / \mathrm{gal}, \Sigma_{\mathrm{a}}$ for the boric acid is 0.0276 . The difference in $\Sigma_{\mathrm{a}}$ above and $\Sigma_{\mathrm{a}}$ due to boric acid is 0.0079 , which must then represent roughly the effective $\Sigma_{\mathrm{a}}$ of the poison rods. An error is present, of course, in ignoring the boric acid effect in the water reflector.

C. Metal-to-Water Optimization Studies

\section{Purpose}

At various times during the BORAX-V program, and as operational scheduling would permit, experiments were carried out in an attempt to optimize the metal-to-water ratios to obtain the maximum available excess reactivity. The metal-to-water ratio was variable because of the provision for replacing selected fuel rods with water-containing or "flow" rods. The term "flow rods" was derived from the consideration that their presence would maintain the same hydraulic conditions as the fuel rods. Of the same diameter as the fuel rods, the flow rods were made of X-8001 alloy aluminum tubing with a wall thickness of 0.020 in. Holes were drilled at each end to permit the rods to be filled with water.

The full 49-fuel-rod assembly proved to be somewhat undermoderated. Cadmium ratios obtained on the BORAX exponential experiment gave values ranging from 14 at the assembly edge to six near the center. Enriched uranium-zirconium wires, both bare and clad with 0.020-in.-thick cadmium, were used for this measurement. A comparison of various lattice spacings from the ZPR-7 results* indicated that a maximum reactivity would result when 12 of the 49 rods were flow rods. Actually, a gain in reactivity, at room temperature, may not in itself be the desired objective, for this would need suppression by extra poison rods to avoid the possibility of achieving criticality upon the withdrawal of a single control rod. The benefit would be expected from a reduced temperature and void coefficient.

\section{Cell Problems}

In an effort to guide the experimental work, a series of PDQ cell problems was run to observe the effect of flow-rod location on power distribution and to obtain a disadvantage factor for the assembly. The disadvantage factor was also used to adjust homogenized number densities for new reactor thermal constants.

Figure 17 illustrates the particular flow-rod geometries characterizing the several BORAX-V cores, and Fig. 18 depicts the cell model used for two-group $P D Q$ problems. Cross sections for the several regions

*Made by D. H. Shaftman, Reactor Physics Division, ANL. 


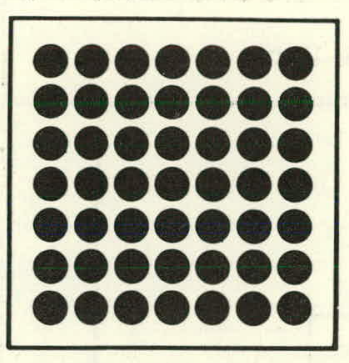

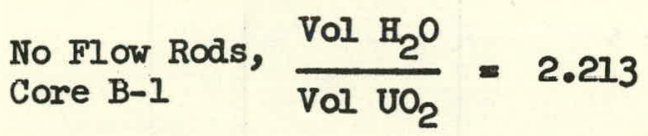

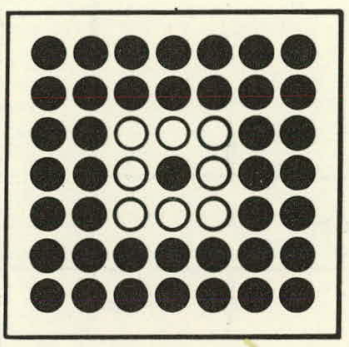

8 Flow Rods,
Core CSH-1

Fuel Rod

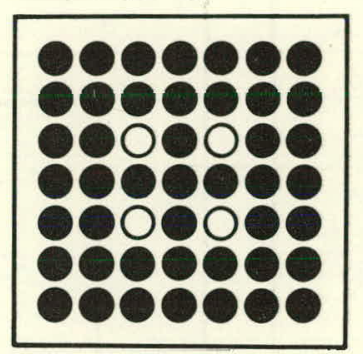

$\begin{aligned} & 4 \text { Flow Rods, } \\ & \text { Core B-2 }\end{aligned} \frac{\text { Vol } \mathrm{H}_{2} \mathrm{O}}{\mathrm{Vol} \mathrm{UO}_{2}}=2.561$

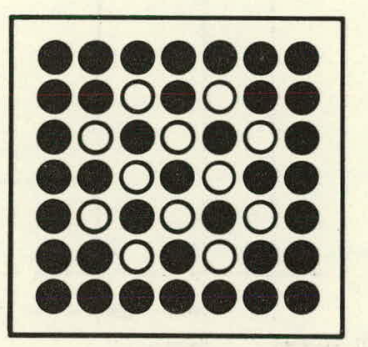

$\begin{aligned} & 12 \text { Flow Rods, } \\ & \text { Core PSH-1 }\end{aligned} \frac{\mathrm{Vol} \mathrm{H}_{2} \mathrm{O}}{\mathrm{VOI} \mathrm{\textrm {UO } _ { 2 }}}=3.319$

O Flow Rod

Note:

Water-to-UO ratios are given for

the cold reactor and include water

in the interassembly regions.

ID-103-A3509

Fig. 17. Flow-rod Patterns in Boiling Fuel Assembly 


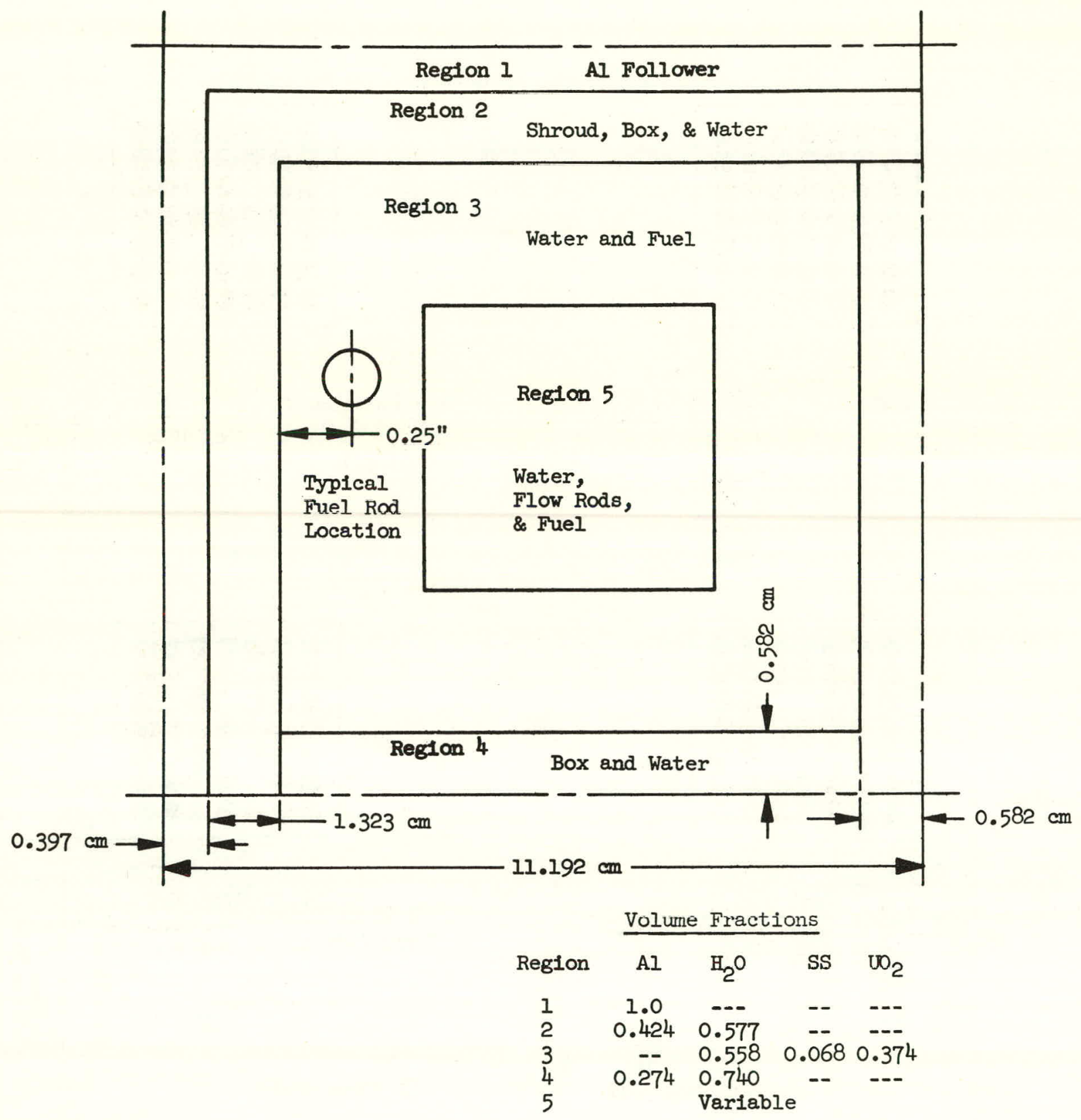

ID-103-A3520

Fig. 18. Calculational Cell Model for a Single Boiling Fuel Assembly

were derived by methods previously described, with the exception of the resonance self-shielding factors wherein the Dancoff correction was evaluated by considering each fuel rod of a fuel region and including the contribution of every neighboring rod within two lattice distances ( 1 in.).

The thermal disadvantage factors to associate with fuel rods in the mixed fuel and flow region were not corrected. No simple expedient for this seemed to exist, although a later thought of finding an average "effective" lattice spacing to use in computing an adjusted disadvantage factor might afford some improvement (see Section III-D). 
Figure 19 compares thermal fluxes plotted from the PDQ results for the representative BORAX-V cores. The plots are normalized on a point-to-average basis, where the average is the volume average of the fuel regions, rather than the profile average. Comparison with measured flux patterns obtained with enriched uranium-zirconium wires, if made on the basis of the ratio of maximum (on line of traverse and within fuel region) to minimum, gave values for the 49-fuel-rod assembly ranging from about 3.4 to 2.6 , the larger value being near the core center. The equivalent cell problem gave a value of about 2.0 , but some difference would be expected from the fact that the calculation is based on a thermal flux averaged to $0.625 \mathrm{eV}$, whereas the $\mathrm{U}^{235}$ activation was quite sensitive to variations in the detailed spectrum.

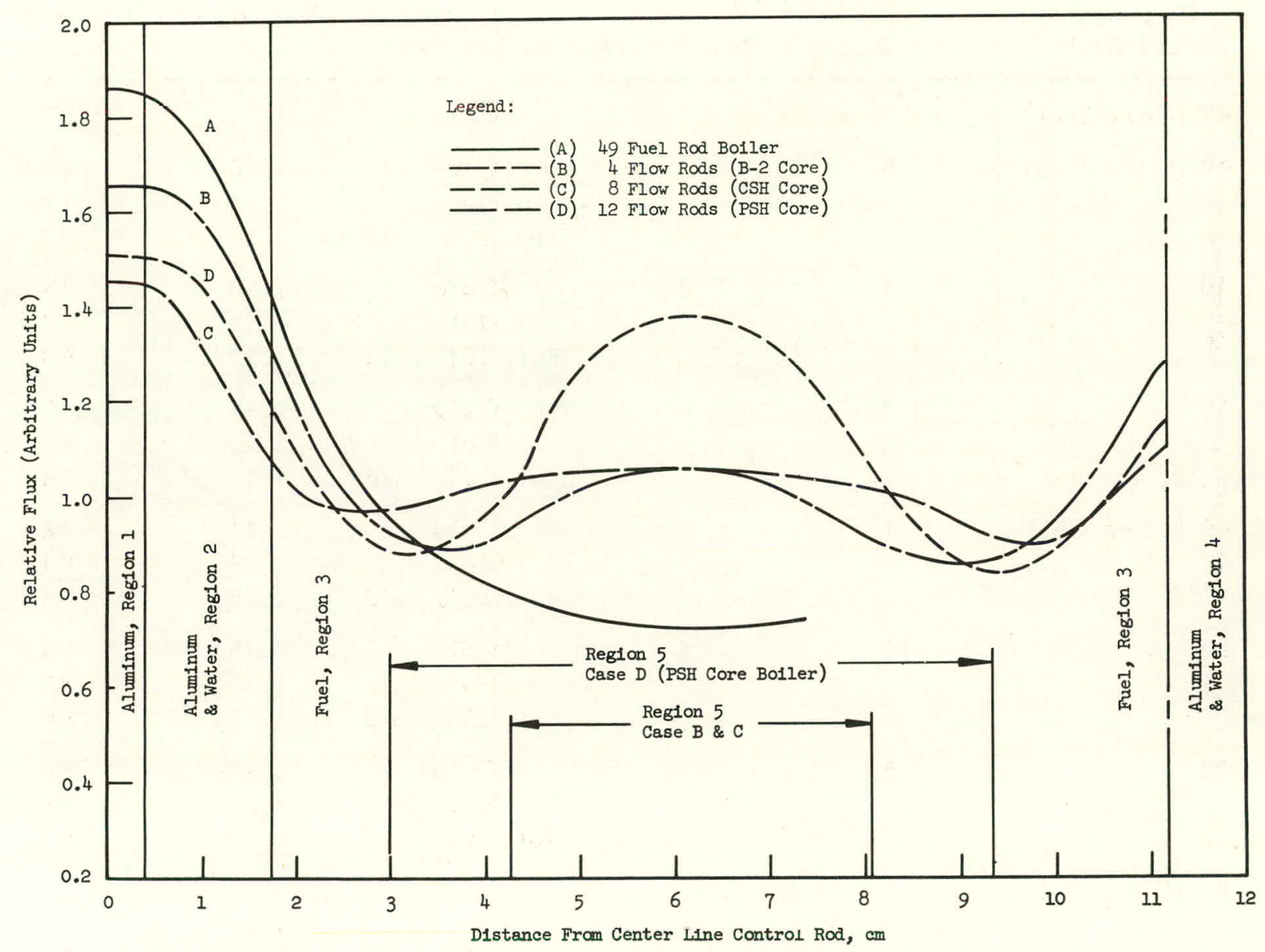

ID-103-A3507

Fig. 19. Thermal Flux Patterns from PDQ Cell Problems

The various combinations of flow and fuel rods considered are listed in Table VIII, together with the values of the ratio $\bar{\phi}_{\text {nonfuel }} / \bar{\phi}_{\text {fuel }}$ for the thermal group. Cold (room temperature), hot $\left(489^{\circ} \mathrm{F}\right)$, and hot with $10 \%$ steam void (fuel-rod region only) cores are listed. The ratio is calculated as follows: 
$\frac{\bar{\phi}_{\text {nonfuel region }}}{\bar{\phi}_{\text {fuel region }}}=\frac{\frac{\int_{\text {Reg 1 }} \phi \mathrm{dv}+\int_{\mathrm{Reg} 2} \phi \mathrm{dv}+\int_{\mathrm{Reg} 4} \phi \mathrm{dv}}{\text { Volume of Regions } 1,2, \text { and 4 }}}{\frac{\int_{\text {Reg } 3} \phi \mathrm{dv}+\int_{\operatorname{Reg} 5} \phi \mathrm{dv}}{\text { Volume of Regions } 3 \text { and 5 }}}$.

TABLE VIII. Thermal Flux Ratios of Nonfuel-to-fuel Regions;

Two-group PDQ Cell Results

\begin{tabular}{|c|c|c|c|c|c|}
\hline \multicolumn{3}{|c|}{ Fuel-region Geometry } & \multirow{3}{*}{$\begin{array}{l}\text { Condition } \\
\text { of Reactor* }\end{array}$} & \multirow{3}{*}{$\frac{\bar{\phi}_{\text {nonfuel }}}{\bar{\phi}_{\text {fuel }}}$} & \multirow{3}{*}{$\begin{array}{c}\text { PDQ } \\
\text { Problem } \\
\text { No. }\end{array}$} \\
\hline \multirow{2}{*}{$\begin{array}{l}\text { Region 3, } \\
\text { Fuel Rods }\end{array}$} & \multicolumn{2}{|c|}{ Region 5} & & & \\
\hline & Fuel Rods & Flow Rods & & & \\
\hline 49 (Core B-1) & & & Cold & 1.77 & 22067 \\
\hline \multirow[t]{3}{*}{40 (Core B-2) } & 5 & 4 & Cold & 1.55 & 76 \\
\hline & & & Hot & 1.38 & 77 \\
\hline & & & Hot, $10 \%$ void & 1.40 & 92 \\
\hline \multirow[t]{3}{*}{40} & 4 & 5 & Cold & 1.52 & 78 \\
\hline & & & Hot & 1.34 & 79 \\
\hline & & & Hot, $10 \%$ void & 1.37 & 93 \\
\hline \multirow[t]{3}{*}{40} & 3 & 6 & Cold & 1.49 & 80 \\
\hline & & & Hot & 1.31 & 81 \\
\hline & & & Hot, $10 \%$ void & 1.33 & 94 \\
\hline \multirow[t]{3}{*}{40 (Core CSH) } & 1 & 8 & Cold & 1.41 & 82 \\
\hline & & & Hot & 1.24 & 83 \\
\hline & & & Hot, $10 \%$ void & 1.27 & 95 \\
\hline \multirow[t]{3}{*}{24} & 17 & 8 & Cold & 1.45 & 84 \\
\hline & & & Hot & 1.33 & 85 \\
\hline & & & Hot, $10 \%$ void & 1.34 & 96 \\
\hline \multirow[t]{3}{*}{24} & 16 & 9 & Cold & 1.42 & 86 \\
\hline & & & Hot & 1.30 & 87 \\
\hline & & & Hot, $10 \%$ void & 1.32 & 97 \\
\hline \multirow[t]{3}{*}{24 (Core PSH) } & 13 & 12 & Cold & 1.36 & 88 \\
\hline & & & Hot & 1.21 & 89 \\
\hline & & & Hot, $10 \%$ void & 1.23 & 98 \\
\hline \multirow[t]{3}{*}{0} & 33 & 16 & Cold & 1.43 & 90 \\
\hline & & & Hot & 1.31 & 91 \\
\hline & & & Hot, $10 \%$ void & & \\
\hline
\end{tabular}

*Cold: room temperature.

Hot: $489^{\circ} \mathrm{F}$. 


\section{Reactor Problems}

The above ratio was treated as an assembly disadvantage factor and applied to the fuel and nonfuel atom densities in accordance with the rule previously listed, and input for new homogenized SOFOCATE problems was obtained. Unaltered averaged atom densities were used in MUFT calculations for fast cross sections. A new resonance self-shielding factor was obtained wherein the Dancoff correction was made for an averaged fuel region. The cross sections thus obtained are given as Appendix $\mathrm{B}$, and a condensed summary of reactor calculations (three-group, RE-122) as Table IX. The old superheater constants were used. Included in the table are values of $k_{\text {eff }}$ for the case of peripheral superheater elements used in the central superheater configuration.

TABLE IX. Calculated keff for Representative Flow-rod Geometries and Comparative Reactivity Effects, Three-group RE-122

Radial (One-dimensional) Problems

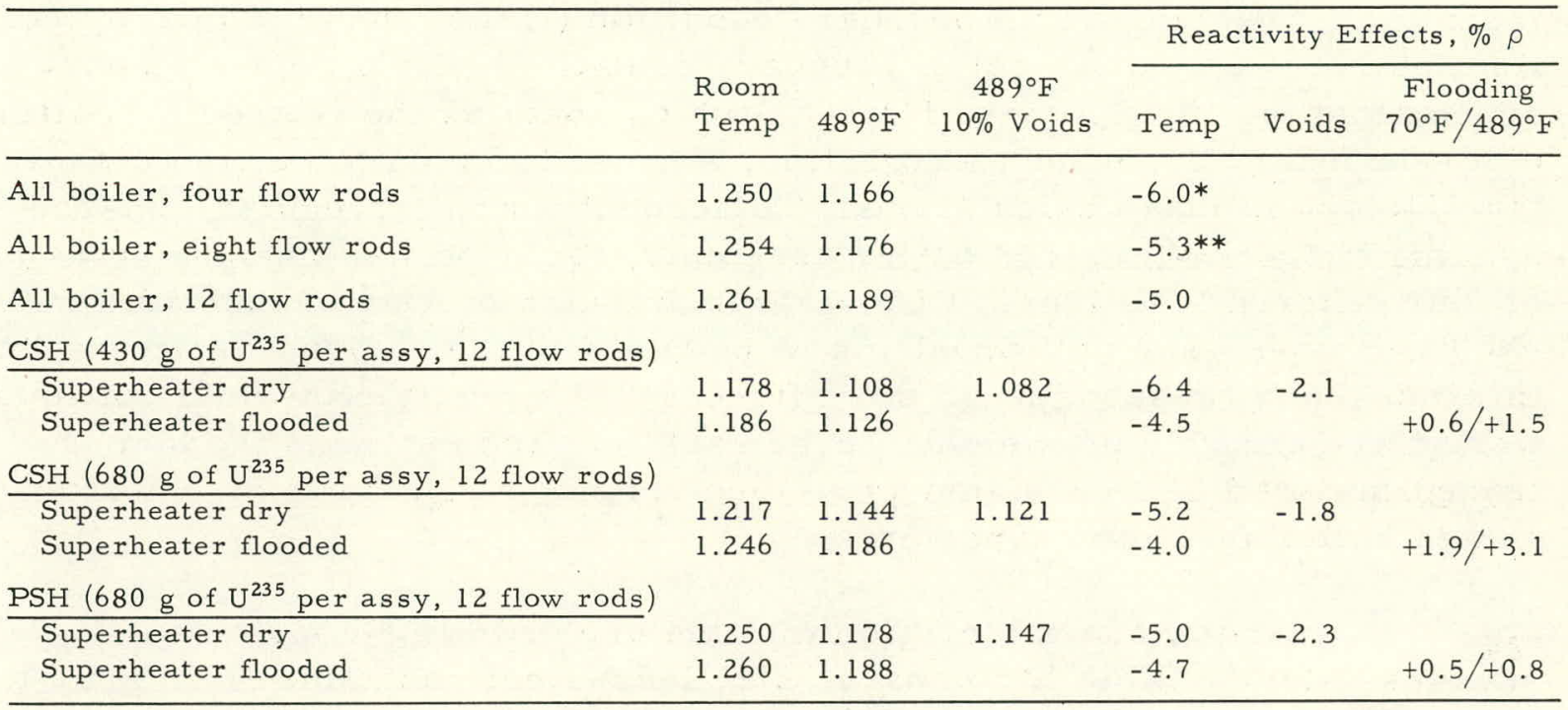

Superheater power fraction, $489^{\circ} \mathrm{F}, 10 \%$ average steam void:

$680 \mathrm{~g}$ of $\mathrm{U}^{235}$ per assy, central superheater: 0.22

$680 \mathrm{~g}$ of $\mathrm{U}^{235}$ per assy, peripheral superheater: 0.14.

*Comparative experimental value for B-2: -4.6 .

**Comparative experimental value for $\mathrm{CSH}-1:-3.9$.

The effect of spiking the outer three corner elements of each quadrant with fuel rods of double enrichment, to an equivalent of $7.5 \mathrm{w} / \mathrm{o}$ enriched within the assembly, gave a reactivity gain ( $P D Q$ calculation) of $0.4 \%$. If the spiking were to be done in the outer row of boiler fuel assemblies as well, the calculation indicates that $2.4 \% \rho$ would then be gained, but that the superheater power fraction would lose $4 \%$ of its original value. The superheater was considered to be flooded and the reactor at room temperature in these computations. 
D. Detailed Calculations

1. Introduction

Because of the extreme heterogeneity of the BORAX-V cores, especially core PSH-1, much consideration has been given to the question of how best to develop a calculational model. Many of the methods used in previous work have been discussed earlier in this report.

Later developments in calculational technique indicated that it would be possible to significantly improve calculated predictions of reactor behavior, and this has proved to be true. For example, to homogenize the boiler fuel rod and water over a specified region, what is the best way to obtain disadvantage factors, especially when the fuel-rod lattice spacing is irregular? For cylindrical fuel-rod cells, it has been shown ${ }^{15}$ that flux distribution in good agreement with experiment can be obtained by applying an isotropic-scattering outer-boundary condition (rather than the mirror reflection, or zero-derivative outer-boundary condition) in a transport-theory. approximation. $\mathrm{An}_{\mathrm{n}}$ code, TOPIC, ${ }^{29}$ which contains the is otropic-scattering outer-boundary condition as an option, was used to obtain thermal disadvantage factors in these calculations. To account for the irregular fuel-rod spacing in the 12-flow-rod boiler assembly, each rod was designated as one of four different cell types, with various amounts of water associated with each cell type. The cell problems were run with the various water annulus thicknesses corresponding to the different cell types, the thermal constants were flux- and volume-weighted over each fuel rod cell, and the homogenized fuel-rod cell constants were then volume-weighted to give homogenized boiler fuel zone constants.

Another consideration was the use of MUFT constants for stainless steel. Table X compares stainless-steel constants from MUFT with those obtained from GAM-I. ${ }^{11}$ Since GAM stainless-steel constants were considered to be much better than those from MUFT, GAM was used to obtain three fast-group constants.

TABLE X. Comparison of MUFT Constants for Type 304 Stainless Steel with GAM-I Constants

\begin{tabular}{cllll}
\hline Group & \multicolumn{1}{c}{$\mathrm{D}$} & \multicolumn{1}{c}{$\Sigma_{\mathrm{a}}$} & \multicolumn{1}{c}{$\Sigma_{\mathrm{r}}$} & Constant Set \\
\hline 1 & 1.03242 & 0.00005 & 0.040339 & MUFT \\
1 & 1.65398 & 0.000235 & 0.029859 & GAM-I \\
2 & 0.35002 & 0.0 & 0.003815 & MUFT \\
2 & 0.80840 & 0.001380 & 0.003502 & GAM-I \\
3 & 0.38939 & 0.04996 & 0.000269 & MUFT \\
3 & 0.35042 & 0.014021 & 0.002642 & GAM-I \\
\hline
\end{tabular}


A new $U^{238}$ cross-section set from Hanford's RBU library ${ }^{30}$ has been added to the ANL GAM-I library. Comparison of this cross-section set with BNL-325 indicates much better agreement than the original GAM-I $\mathrm{U}^{238}$ cross sections. Use of this new set, called element No. 139, has been shown ${ }^{31}$ to predict $\mathrm{k}_{\text {eff }}$ for low-enriched water-moderated systems much more accurately than has been possible by using the old element No. 12 in GAM.

Although these calculations incorporated such considerations, they could be improved in several ways. For example, a double P-l approximation in slab geometry was used to flux-weight the constants in the superheater fuel region. A better approximation could be used. More important, and because of a time limitation, the boron-stainless steel poison-rod constants were hand-generated by using tabulated values for flux depression rather than actually running poison-rod cell problems. Also, the description of the reactor could be further improved by using more mesh points than the 7500 allowed in PDQ $-3 .^{32}$

In spite of these "flaws," the calculations gave remarkably good agreement with experiment, resulting in calculated $k_{\text {eff }}$ values less than $1.5 \%$ high, and in some cases less than $0.2 \%$ high (see Table XI).

\section{Constants}

Thermal constants for the final BORAX computations were obtained by using TEMPEST ${ }^{12}$ to average constants for rod-cell or platecell regions over a homogenized fuel-assembly (including box, shroud, and control-rod follower) spectrum. These cell constants were used to obtain the thermal flux distribution over fuel cells, and were then flux- and volumeweighted to produce homogenized PDQ fuel-zone constants. Thermal constants for homogenized material zones outside a fuel region were obtained by averaging the volume-weighted constants over the appropriate homogenized assembly spectrum. The atomic densities for the various materials are listed in Appendix C.

The boiler fuel-rod cell calculations used TOPIC, ${ }^{29}$ a cylindrical $\mathrm{S}_{4}$ code that has an isotropic-scattering outer-boundary condition. A comparison of the ratio of average-to-edge flux in the fuel rod and the disadvantage factor (defined as the ratio of the average flux in the moderator to the average flux in the nonmoderator) obtained from TOPIC with measured values $^{8}$ for $4.95 \mathrm{w} / \mathrm{o}$-enriched fuel rods in a 0.5 -in. center-to-center lattice indicates good agreement. The experimentally measured ratio of averageto-edge flux in the fuel rod was 0.91 (no experimental error given); the value calculated in the present work is 0.90 . The experimentally measured disadvantage factor was 1.18 (not corrected for flux perturbation in water channel due to flux wires). If the experimentally measured value of $\bar{\phi}\left(\mathrm{H}_{2} \mathrm{O}\right) / \bar{\phi}$ (fuel rod) were corrected for the wire perturbation, it would agree well with the calculated value of 1.25 . 
TABLE XI. Comparison of Calculation and Experiment, Minimum Critical Assemblies

\begin{tabular}{|c|c|c|c|}
\hline Configuration & $\begin{array}{l}\text { Experimental } \\
k_{\text {eff }}\end{array}$ & $\begin{array}{l}\text { Calculated } \\
\text { keff }\end{array}$ & $\begin{array}{l}\text { PDQ Problem Number } \\
\text { and Description }\end{array}$ \\
\hline \multirow[t]{6}{*}{$\begin{array}{l}\text { Sixteen } 680-\mathrm{g} \\
\text { superheater assemblics, } \\
\text { flooded }\end{array}$} & $<1.000$ & $1.0195 \pm 0.0025$ & $\begin{array}{c}1001 \\
\text { Fine mesh } \\
\text { SS spacers omitted }\end{array}$ \\
\hline & & $1.0201 \pm 0.0025$ & $\begin{array}{c}1002 \\
\text { Coarse mesh } \\
\text { SS spacers omitted }\end{array}$ \\
\hline & & $1.0100 \pm 0.0025$ & $\begin{array}{c}1003 \\
\text { Fine mesh } \\
\text { SS spacers included }\end{array}$ \\
\hline & & $1.0109 \pm 0.0025$ & $\begin{array}{c}1004 \\
\text { Coarse mesh } \\
\text { SS spacers included }\end{array}$ \\
\hline & & $0.9896+0.0009$ & 1005 \\
\hline & & & $\begin{array}{l}\text { Coarse mesh corresponding } \\
\text { to PSH-l quarter-core PDQ, } \\
\text { SS spacers included }\end{array}$ \\
\hline \multirow[t]{4}{*}{$\begin{array}{l}12 \text {-flow-rod-boiler } \\
\text { minimum critical slab, } \\
\text { no poison rods }\end{array}$} & 1.00 .43 & $1.0308 \pm 0.0025$ & $\begin{array}{l}2001 \\
\text { Fine mesh, using } \\
\text { GAM No. } 12 \text { for } \mathrm{U}^{238}\end{array}$ \\
\hline & & $1.0292 \pm 0.0025$ & $\begin{array}{l}\quad 2002 \\
\text { Coarse mesh, using } \\
\text { GAM No. } 12 \text { for } U^{238}\end{array}$ \\
\hline & & $1.0060 \pm 0.0025$ & $\begin{array}{l}2003 \\
\text { Fine mesh, using } \\
\text { GAM No. } 139 \text { for } \mathrm{U}^{238}\end{array}$ \\
\hline & & 1.004410 .0025 & $\begin{array}{l}\quad 2001 \\
\text { Coarse mesh, using } \\
\text { GAM No. } 139 \text { for } \mathrm{U}^{238}\end{array}$ \\
\hline $\begin{array}{l}\text { 12-flow-rod-boiler } \\
\text { minimum critical slab, } \\
\text { two poison rods }\end{array}$ & 1.0023 & $1.0032 \pm 0.0004$ & $\begin{array}{l}2005 \\
\text { Fine mesh, using } \\
\text { GAM No. } 139 \text { for } U^{238}\end{array}$ \\
\hline
\end{tabular}

The 12-flow-rod boiler assembly was broken down into four different cell types, depending on flow- and fuel-rod arrangements, as shown in Fig. 20. Each fuel rod was associated with a certain volume of water surrounding it and was designated as one of the four types. The model used for the cell calculations is shown in Fig. 21, and the thermal cross sections for each cell type are given in Appendix D. To obtain PDQ homogenized fuel-zone constants, the flux- and volume-weighted constants from each cell type were volume-weighted by the fraction of total fuel-zone volume occupied by the particular cell type. The dashed line shown in Fig. 20 indicates the boundary of the PDQ boiler fuel zone. Use of this boundary required the subtraction of water from the affected Type 1 cells. This was accomplished by flux-weighting the Type 1 cell-region constants 
as though they actually covered the entire 0.5 -in. square, but volumeweighting with the actual water volume as indicated by the dashed line in Fig. 20 .

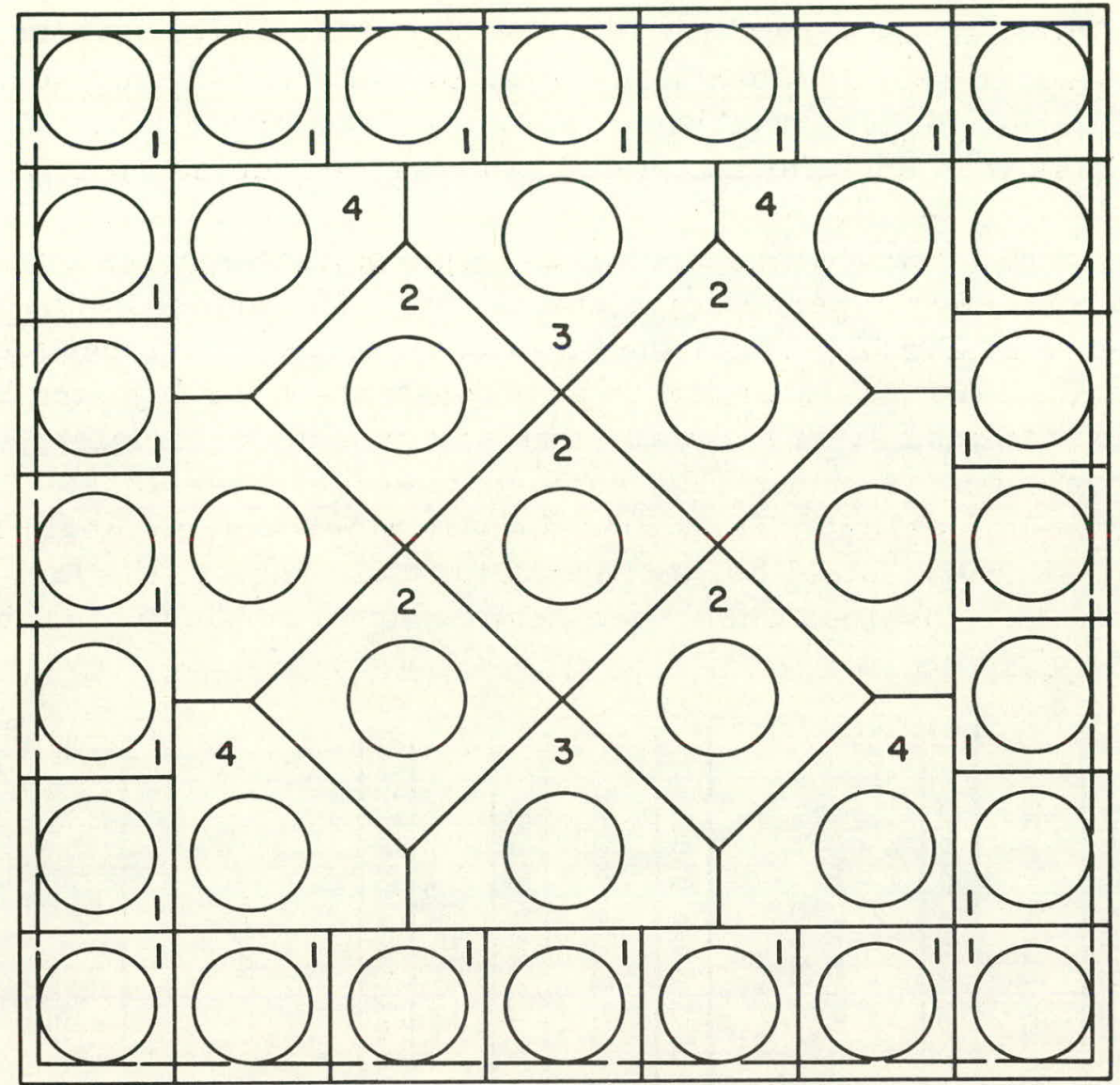

Note:

Numbers Refer to Cell Type

ID-103-A 3532

Fig. 20. Cell Types in 12-flow-rod Boiler Assembly

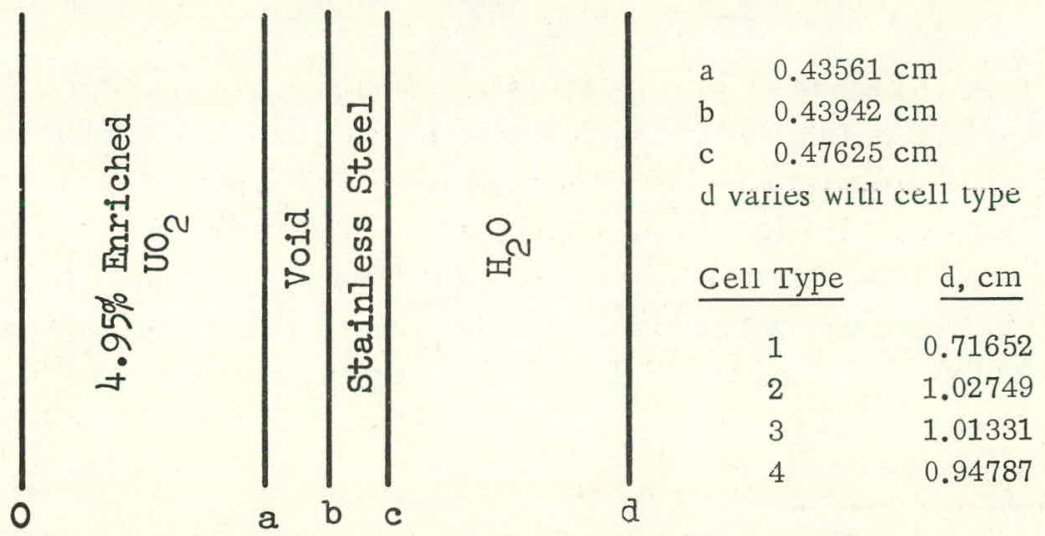

ID-103-A3536

Fig. 21. Calculational Model for Boiler Fuel-rod Cell Calculation 
Two possible improvements can be indicated here. The homogenized cell constants should be both flux- and volume-weighted over the entire fuel zone to obtain homogenized fuel-zone constants. In the case of the 12-flow-rod boiler assembly, however, the thermal flux across the fuel zone is quite flat, as shown in Fig. 19. Hence, the error involved here is small. Also, it would probably be better to use a two-dimensional assembly cell calculation for flux-weighting the outer rows of fuel rods, but for the present case it is doubtful that much improvement could be gained.

FLIP- $1^{33}$ (with a double P-1 approximation) was employed similarly on the 680-g superheater element cell. The model for these calculations, shown in Fig. 22, omits the stainless-steel spacers between fuel plates; therefore, the water (or steam) constants were adjusted by volumeweighting stainless steel and water (or steam) constants before flux- and volume-weighting to obtain $\mathrm{PDQ}$ homogenized fuel-zone constants. Since the PDQ model explicitly described the water between elements and the combined stainless-steel box and insulator-void region, the fuel-region homogenization involved only those regions up to and including the outer fuel-plate cladding in Fig. 22.
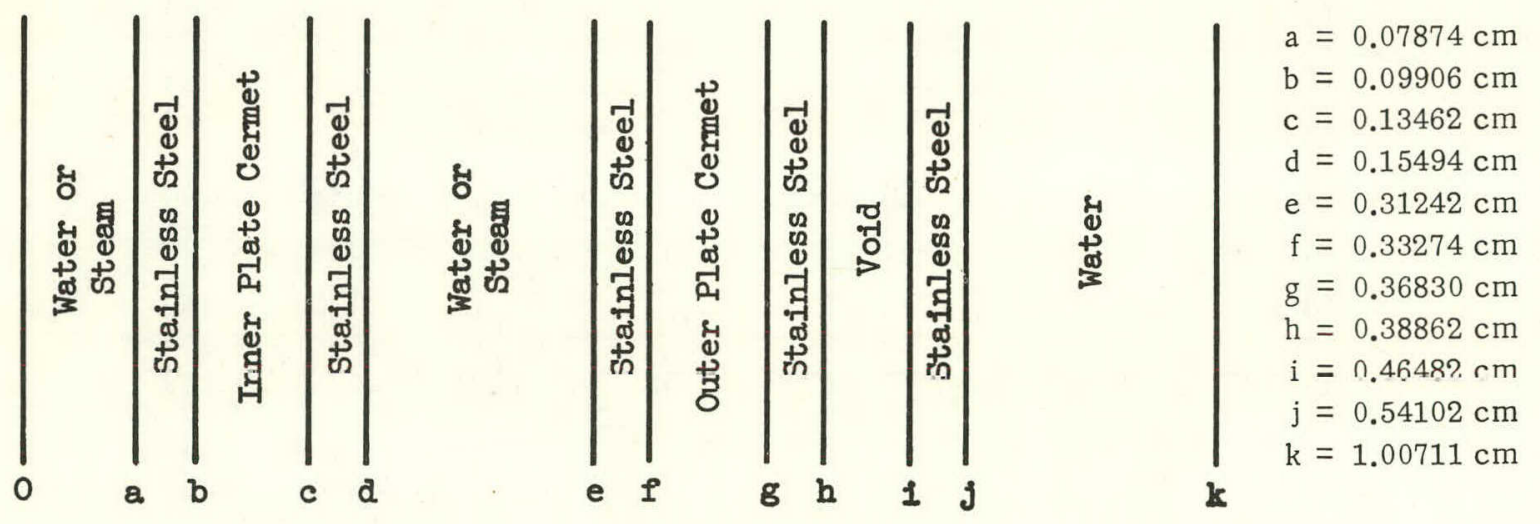

ID-103-A3529

Fig. 22. Calculational Model for Superheater Fuel-element Cell Calculation

The three fast group constants were obtained from GAM-I ${ }^{11}$ by first obtaining the fast spectrum for the homogenized fuel assembly and then averaging the constants for individual PDQ material zones over that spectrum. The boiler fuel-zone constants, however, were averaged over the spectrum for boiler fuel-zone material only. Constants for control-rod poison material (boral) were obtained by using the "blackness theory" $34,35,36$ option* in GAM-I and TEMPEST and the appropriate homogenized boilerassembly spectrum. The four-group constants for the PDQ material zones are tabulated in Appendix E.

*This option was added to the Phillips Petroleum Company versions of GAM-I and TEMPEST by

L. A. Schmittroth and R. L. Curtis. 
A significant improvement in the superheater fuel-zone constants would be obtained by doing four-group element cell calculations and flux- and volume-weighting the cell-region constants for all four groups rather than for only the thermal group.

\section{PDQ Problems and Results}

Minimum critical experiments were done with both 680-g superheater assemblies and 12-flow-rod boiler assemblies, and the results of these experiments were used as a basis for judging the validity of the fourgroup constants in Appendix E. Unfortunately, criticality was not achieved with sixteen $680 \mathrm{~g}$ superheater assemblies, and only 16 were available. However, it was estimated from inverse count-rate curves that 18 assemblies would be supercritical and 17 would be nearly critical. The arrangement of the subcritical 16 -assembly array is shown in Fig. 23.

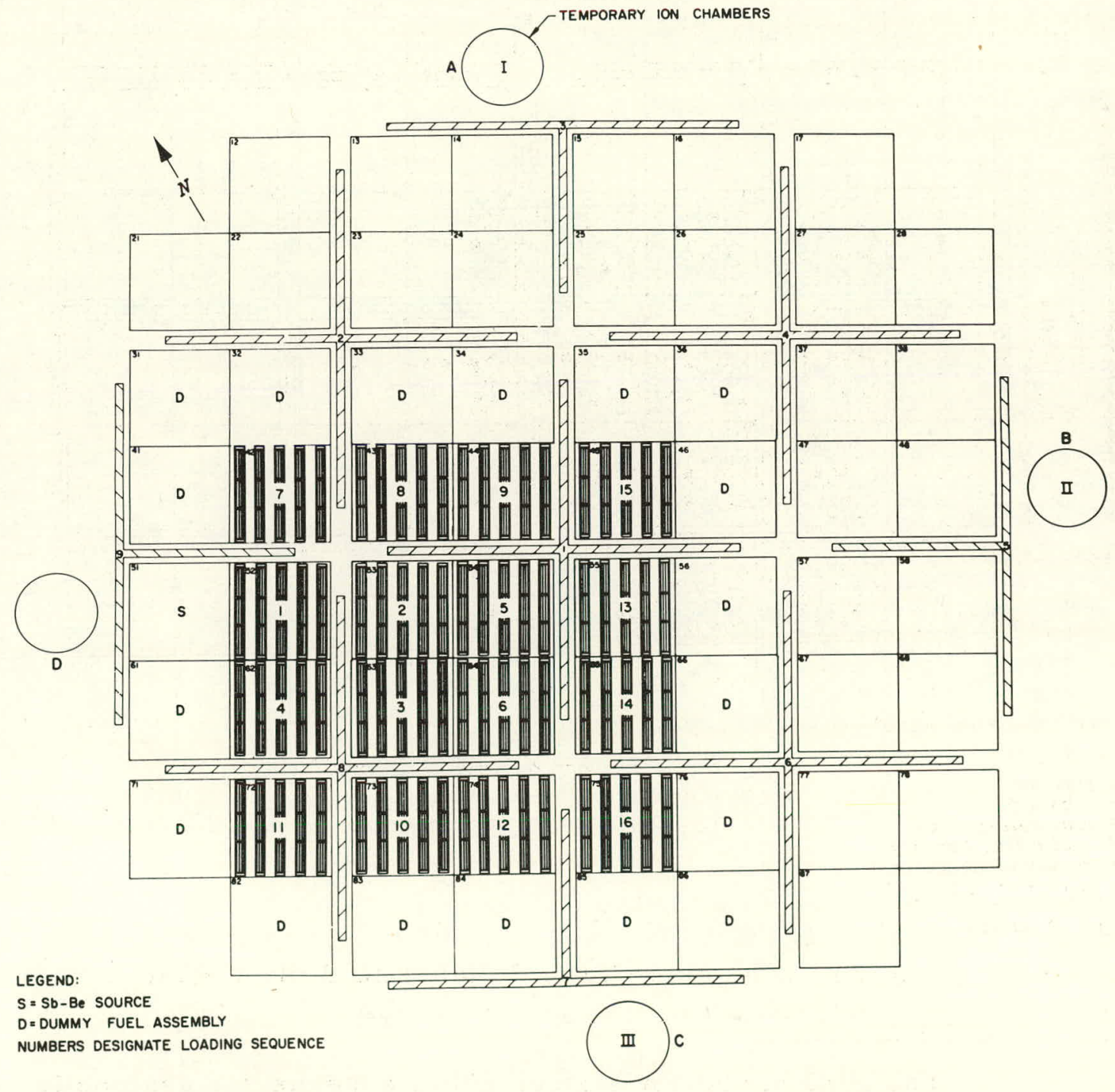

ID-103-A3421

Fig. 23. Sixteen-680-g-superheater-fuel-assembly Array, Minimum Critical Mass Experiment 
With 12-flow-rod boiler as semblies, criticality was achieved with 14 assemblies. Fuel rods and flow rods were rearranged to give the rectangular array shown in Fig. 24. Two boron-stainless steel poison rods were present in the first arrangement, as indicated in Fig. 24, and the

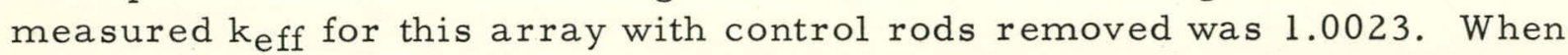
the two poison rods were replaced with fuel rods, keff was estimated to be 1.0043 .

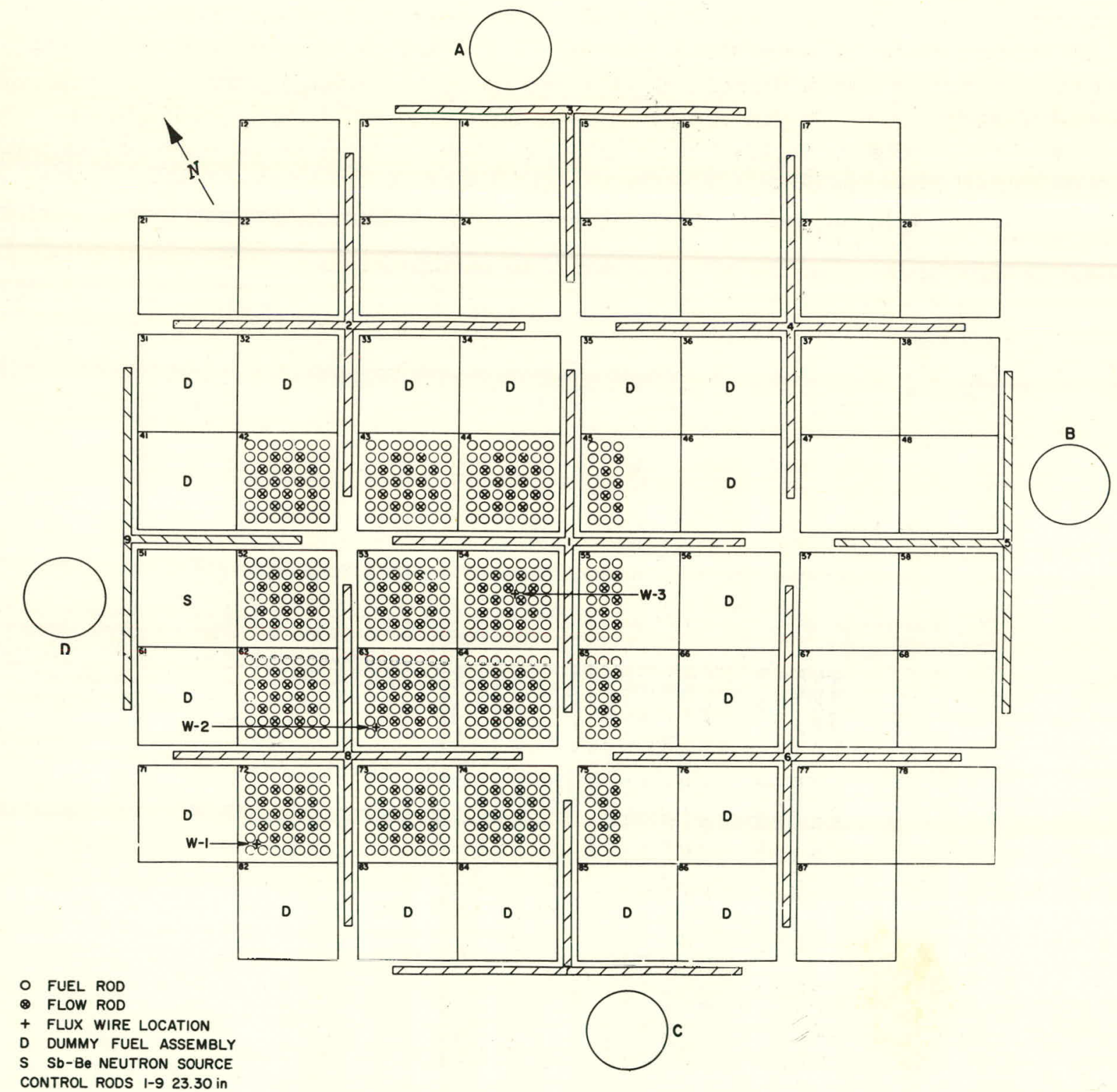

ID-103-A3069

Fig. 24. Minimum Critical Slab with Boiling Fuel, 12 Flow Rods per Assembly

The PDQ model for sixteen 680-g superheater assemblies is shown in Fig. 25, and the model for the 12-flow-rod-boiler minimum critical slab is given in Fig. 26. At least two mesh descriptions were used for 
each of these experiments, a fairly fine mesh and a coarser mesh corresponding to that used in the quarter-core PDQ description of core PSH- 1 . The first superheater problems omitted the $0.062 \times 0.062$-in. stainless-steel spacers between fuel plates, but in later problems they were included. Because of mesh-line limitations, the superheater fuel zone was shortened by $\sim 0.3 \mathrm{~cm}$ on each end to correspond with the line describing the boundaries of the boiler fuel zones, and a problem (No. 1005) was run to determine the effect. The results of these calculations are compared with experiment in Table XI. The agreement between calculation and experiment is quite good, 1\% high for the 680-g superheater assemblies (Problem 1003) and $\sim 0.2 \%$ high for the 12 -flow-rod boiler as emblies.

The effect of decreasing the superheater fuel zones by $0.6 \mathrm{~cm}$ decreased $k_{\text {eff }}$ by $\sim 2 \%$. Because of mesh-line limitations in PDQ-3, a choice was involved in PDQ mesh descriptions (of the PSH-l quarter core) between having adjacent mesh intervals almost a factor of 10 different in width, or using the mesh line that described the boundary of boiler fuel to describe the end of the superheater fuel and shortening the superheater fuel zone by
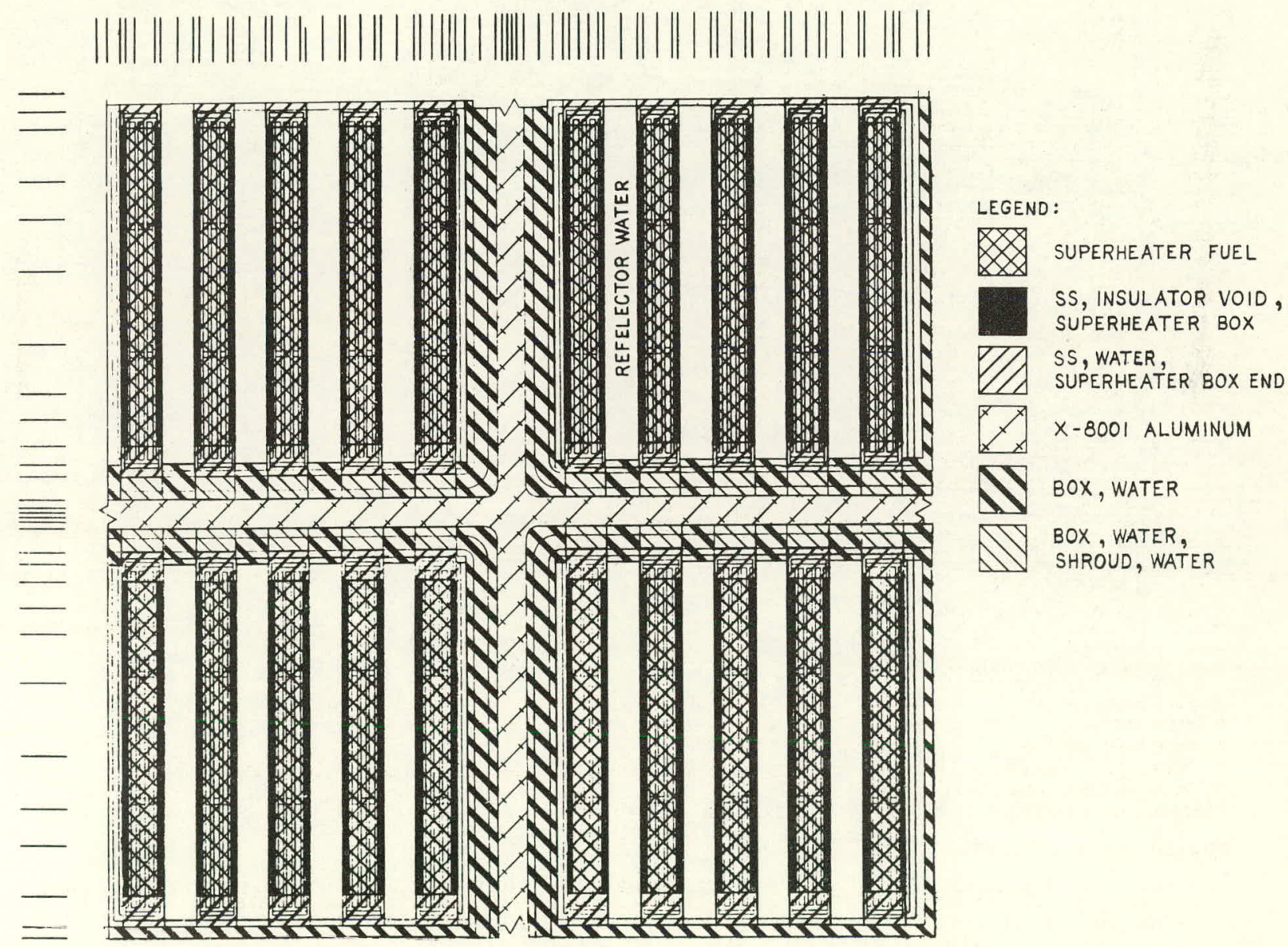

ID-103-A3534

Fig. 25. PDQ-3 Calculational Model for 16-680-gsuperheater-assembly Array 
| |||| | | | | | | |||||| || ||| | | | | | | | ||||
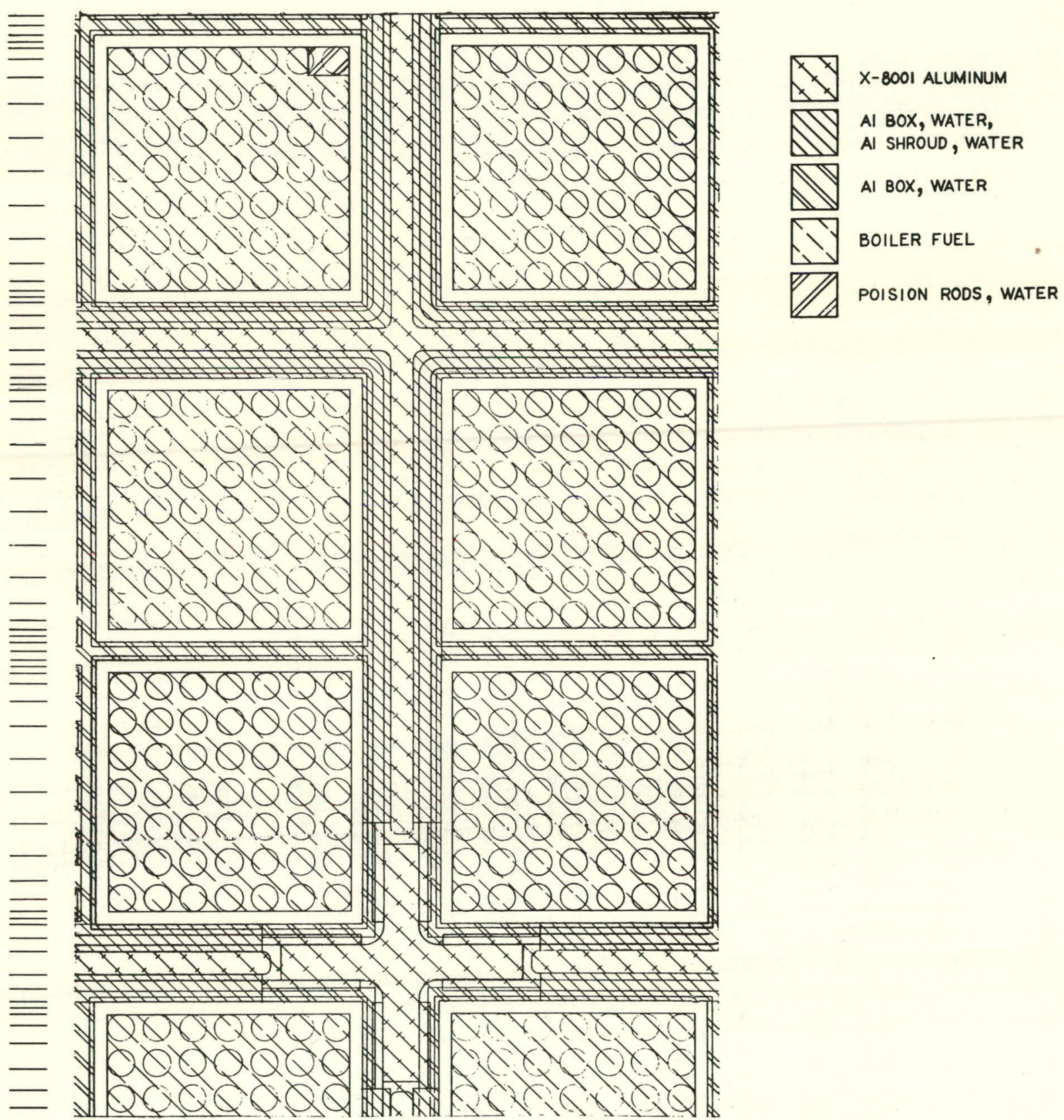

ID-103-A 3517

Fig. 26. PDQ-3 Calculational Model for 12-flowrod-boiler Minimum Critical Slab

$0.6 \mathrm{~cm}$. This and other considerations pertaining to accurate calculation of control-rod worth led to the decision to shorten the superheater fuel zone. The effect of this on the calculated $k_{e f f}$ for the full PSH-l core should be much less than $2 \%$, but this does affect the calculated flooding worth somewhat. Figure 27 shows the PDQ model of a quadrant of the PSH-1 core. 
The results of the problems describing the PSH-1 core are given in Table XII. These results are discussed and compared with experimental measurements in Section IV.

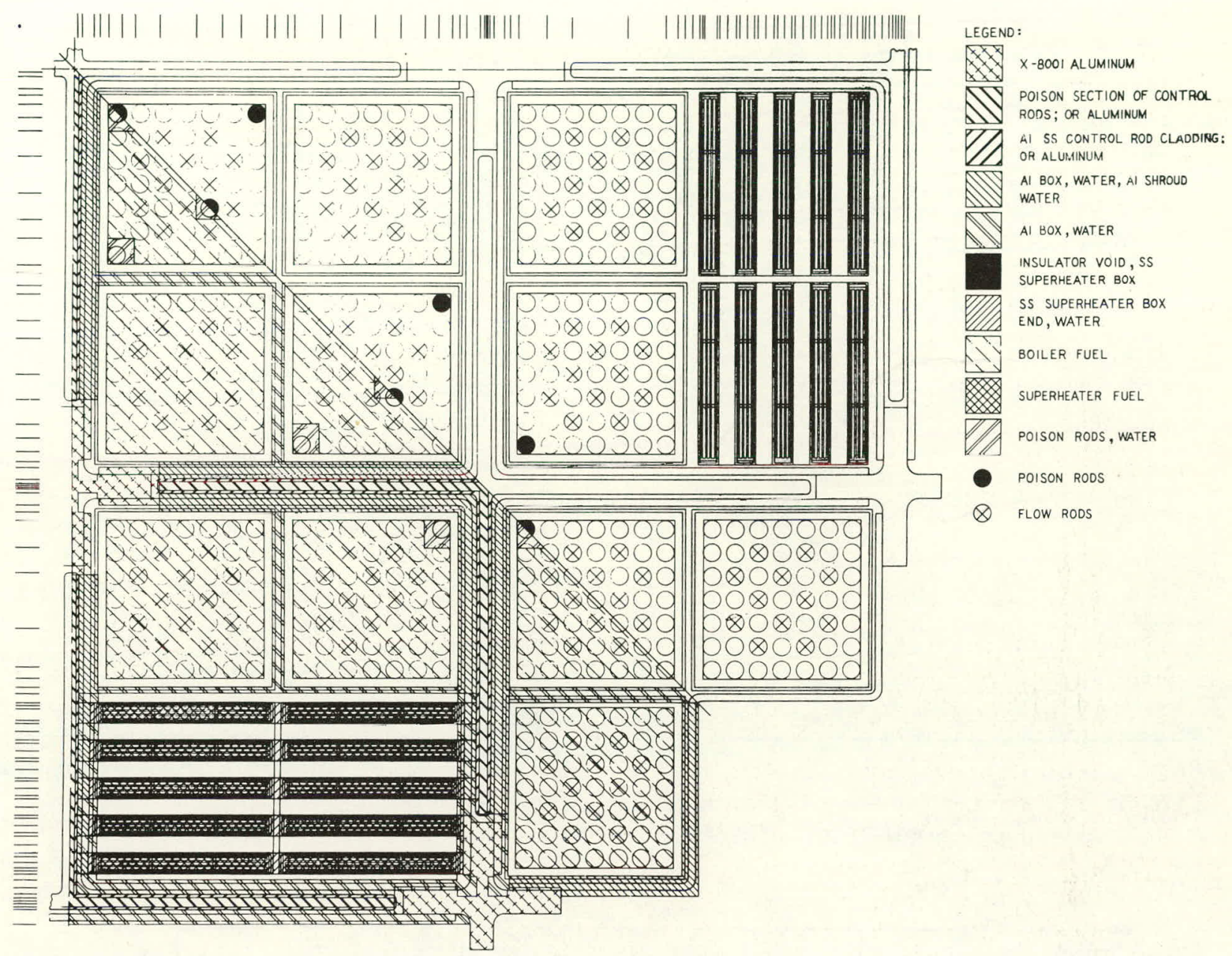

ID-103-A3522

Fig. 27. PDQ Model for Core PSH-1

An anomaly was evidenced in core B-1D control-rod calibration. Experimentally, the calibrations performed during the hot criticals indicated a lesser rod worth than when cold. To examine this paradox, PDQ problems were run. Only a slight modification in the mesh description of the quartercore PSH-l problem was necessary. The constants for the fuel zone were obtained in the same manner as for the 12-flow-rod boiler assembly, using GAM-I element number 139 for $\mathrm{U}^{238}$. Four problems were run with the core B-ID description, and the results are tabulated in Table XIII. 
TABLE XII. Results of PDQ Problems on Core PSH- 1

\begin{tabular}{cccccc}
\hline $\begin{array}{c}\text { PDQ } \\
\text { Problem } \\
\text { No. }\end{array}$ & Temp, ${ }^{\circ} \mathrm{F}$ & $\begin{array}{c}\text { Boric Acid } \\
\text { Concentration }\end{array}$ & $\begin{array}{c}\text { Superheater } \\
\text { Condition }\end{array}$ & $\begin{array}{c}\text { Control-rod } \\
\text { Condition }\end{array}$ & $\begin{array}{c}\text { Calculated } \\
\text { keff } \pm 0.0009\end{array}$ \\
\hline 11001 & 68 & 0 & Flooded & Out & 1.1125 \\
11002 & 68 & 0 & Drained & Out & 1.1005 \\
11003 & 68 & 5 & Drained & Out & 1.0575 \\
11004 & 68 & 10 & Drained & Out & 1.0188 \\
11005 & 68 & 15 & Drained & Out & 0.9845 \\
11006 & 300 & 0 & Flooded & Out & 1.0957 \\
11007 & 489 & 0 & Flooded & Out & 1.0683 \\
11008 & 489 & 0 & Drained & Out & 1.0555 \\
$11009 *$ & $489,10 \%$ voids & 0 & Drained & Out & 1.0268 \\
11010 & 68 & 0 & Flooded & In & 0.8911 \\
11011 & 68 & 0 & Drained & In & 0.8725 \\
11012 & 68 & 5 & Drained & In & 0.8450 \\
11013 & 68 & 10 & Drained & In & 0.8198 \\
11014 & 68 & 15 & Drained & In & 0.7974 \\
11015 & 300 & 0 & Flooded & In & 0.8517 \\
11016 & 489 & 0 & Flooded & In & 0.7956 \\
11017 & 489 & 0 & Drained & In & 0.7768 \\
$11018 *$ & $489,10 \%$ voids & 0 & Drained & In & 0.7469 \\
\hline
\end{tabular}

*To simulate operation at power, the moderator in the fuel zone only was considered to be $10 \%$ voided, and the boiler fuel was assumed to be $900^{\circ} \mathrm{F}$ for the resonance self-shielding calculation in GAM.

TABLE XII. Results of TDQ Problems nn Core B-1D

\begin{tabular}{cccc}
\hline $\begin{array}{c}\text { PDQ } \\
\text { Problem } \\
\text { No. }\end{array}$ & Temp, ${ }^{\circ} \mathrm{F}$ & $\begin{array}{c}\text { Control-rod } \\
\text { Condition }\end{array}$ & $\begin{array}{c}\text { Calculated } \\
\text { keff } \pm 0.0009\end{array}$ \\
\hline 11019 & 68 & Out & 1.1292 \\
11020 & 489 & Out & 1.0805 \\
11021 & 68 & In & 0.8941 \\
11022 & 489 & In & 0.8018 \\
\hline
\end{tabular}




\section{COMPARISON WITH EXPERIMENTS}

A. Core B-1D

One puzzling result of the core B-1D experiments, as mentioned in the preceding section, was the apparent decrease of control-rod worth with increasing temperature. ${ }^{28}$ To determine if such was actually the case, $P D Q$ problems were run with all rods in and all rods out, at 68 and $489^{\circ} \mathrm{F}$. The results of these problems are given in Table XIII. These results indicate that the total rod worth should increase significantly with temperature, contrary to the experimental findings. Table XIV gives the calculated total control-rod worth for both temperatures.

TABLE XIV. Calculated Control-rod Worth,

Core B-1D

\begin{tabular}{cc}
$\begin{array}{c}\text { Temperature, } \\
{ }^{\circ} \mathrm{F}\end{array}$ & $\begin{array}{c}\text { Nine-control-rod-bank } \\
\text { Total Worth, }\end{array}$ \\
\hline 68 & $\mathrm{~K}\left(\right.$ rods out) $-\mathrm{K}_{\text {(rods in })}$ \\
489 & 0.2352 \\
0.2787
\end{tabular}

It must be concluded that some experimental error was made in the hot-rod calibrations. One possible source of error was a fission chamber that had been saturating during the $B-1$ experiments, which might explain the apparent decrease in control-rod worth with temperature. As a result of this error, the measured overall excess reactivity would have been less than the true value, especially at $489^{\circ} \mathrm{F}$.

\section{B. Core PSH-1}

\section{Control-rod Calibration and Available Excess Reactivity;}

The procedure that has been used to calibrate control rods in BORAX cores, as well as in other reactors such as YANKEE, EBWR, and ALPR, involves incremental additions of boric acid to the coolant to allow the control rods to be withdrawn from the just-critical position with no boric acid. The control rods are calibrated at various positions from just critical, no boric acid, to fully withdrawn by withdrawing them slightly from the just-critical position and observing the resulting asymptotic positive period. This period is related to reactivity $(\Delta \mathrm{k} / \mathrm{k})$ by the standard kinetics equation, and at $h+\Delta h / 2$ the control-rod worth is determined as $\Delta \mathrm{k} / \mathrm{k}$ per unit height. 
This method of control-rod calibration introduces an error due to boric acid perturbing the system. However, it has been the consensus that this error is much smaller in magnitude than that introduced by other practicable methods of control-rod calibration. It has also been the consensus that, in systems such as BORAX-V and YANKEE, the effect of boric acid is to decrease control-rod worth. Thus, the available excess reactivity obtained by integrating the control-rod calibration curve (obtained by this method) is an underestimate.

To estimate the effect of boric acid on control-rod worth from the calculated results given in Table XII, the results of experimental measurements rrust bc discussed first. The usual procedure for determining total available excess reactivity has been to plot measured $\% \Delta \mathrm{k} / \mathrm{k} / \mathrm{in}$. as a. function of position, and then to integrate over position from just critical, no boric acid, to fully withdrawn. This supposedly results in total available excess reactivity, or integrated $\% \Delta \mathrm{k} / \mathrm{k}$. But what is the vallue of $\mathrm{k}$ in the denominator? The measured values of reactivity for a change in controlrod position, at least in BORAX-V, are typically in the range of 0.001 to 0.002 . Or, the measured change in $k$ is in the range of 0.001001 to 0.002004 . The result, then, is that the denominator of the integrated $\% \Delta \mathrm{k} / \mathrm{k}$ should be $\sim 1.001$ to 1.002 .

On the other hand, as was pointed out by D. Shaftman,* one can argue from one-group theory that the sum of incremental reactivities over the range of control-rod travel is equal to the reactivity that would be observed if the control rods could be withdrawn completely in one step. With the system just critical, $\mathrm{k}_{0}=\mathrm{C} / \Sigma_{\mathrm{a}}=1$. When the control rods are withdrawn slightly to obtain a small reactivity, $\mathrm{k}_{1}=\mathrm{C} /\left(\Sigma_{\mathrm{a}}-\Delta \Sigma_{\mathrm{a}}^{\prime}\right)$, and the reactivity observed is $\rho_{1}=\left(k_{1}-k_{0}\right) / k_{1} k_{0}=\Delta \Sigma_{a}^{\prime} / C$. Then, enough homogeneous poison is added to add $\Delta \Sigma_{\mathrm{a}}^{\prime}$ back to the absorption cross section, and the system is now critical at the position of the preceding period. The control rods are withdrawn slightly again, and a second reactivity $\rho_{2}$ is measured where $\rho_{2}=\Delta \Sigma_{a}^{2} / C$. These steps are repeated until the control rods have been completely withdrawn.

If the control rods could be withdrawn in one step, the observed total reactivity would be

$$
\rho=\sum_{i} \frac{\Delta \Sigma_{\mathrm{a}}^{\mathrm{i}}}{\mathrm{C}}=\sum_{\mathrm{i}} \rho_{\mathrm{i}}
$$

This says that the sum of the incremental changes in reactivity is equal to the total available reactivity of the system.

Certain approximations are implied in the above hypothetical experiment, among which are the fact that no change is allowed in flux shape

\footnotetext{
* Private communication.
} 
(or importance) along the axis of control-rod travel; and the homogeneous poison added to compensate for control-rod withdrawal is assumed to. have no effect on diffusion length or other system characteristics.

It would seem that a less confusing procedure would be to determine $\Delta \mathrm{k} / \Delta \mathrm{h}$ at each measured point and then to integrate the resulting curve to obtain $k_{\text {eff }}-1$. Then, if it is desired to talk about reactivity, $\rho$, instead of the multiplication factor, $k, \rho$ would result from $\left(k_{\text {eff }}-1\right) / k_{\text {eff }}$. This procedure yields a considerably different result than that obtained by simply integrating $(\Delta \mathrm{k} / \mathrm{k}) / \Delta \mathrm{h}$ and calling the result "total available excess $\mathrm{re}$ activity." To make comparisons with calculations, it is more convenient to discuss things in terms of the multiplication factor, $k$, rather than reactivity, $\rho$.

If control-rod worth at any position is defined as $\Delta \mathrm{k} / \Delta \mathrm{h}$ and total control-rod worth as $\left(k_{\text {out }}-k_{\text {in }}\right)$, and reference is made to Table XII, the total calculated worth for core PSH-1, with superheater drained and no boric acid, is 0.2280 . With $5 \mathrm{~g}$ of $\mathrm{H}_{3} \mathrm{BO}_{3}$ per gallon of $\mathrm{H}_{2} \mathrm{O}$, the worth is 0.2125 ; with $10 \mathrm{~g} / \mathrm{gal}$, the worth is 0.1990 ; and with $15 \mathrm{~g} / \mathrm{gal}$, it is 0.1871 .

The fractional decrease in total control-rod worth as a function of boric acid concentration is shown in Fig. 28. A first thought was that this

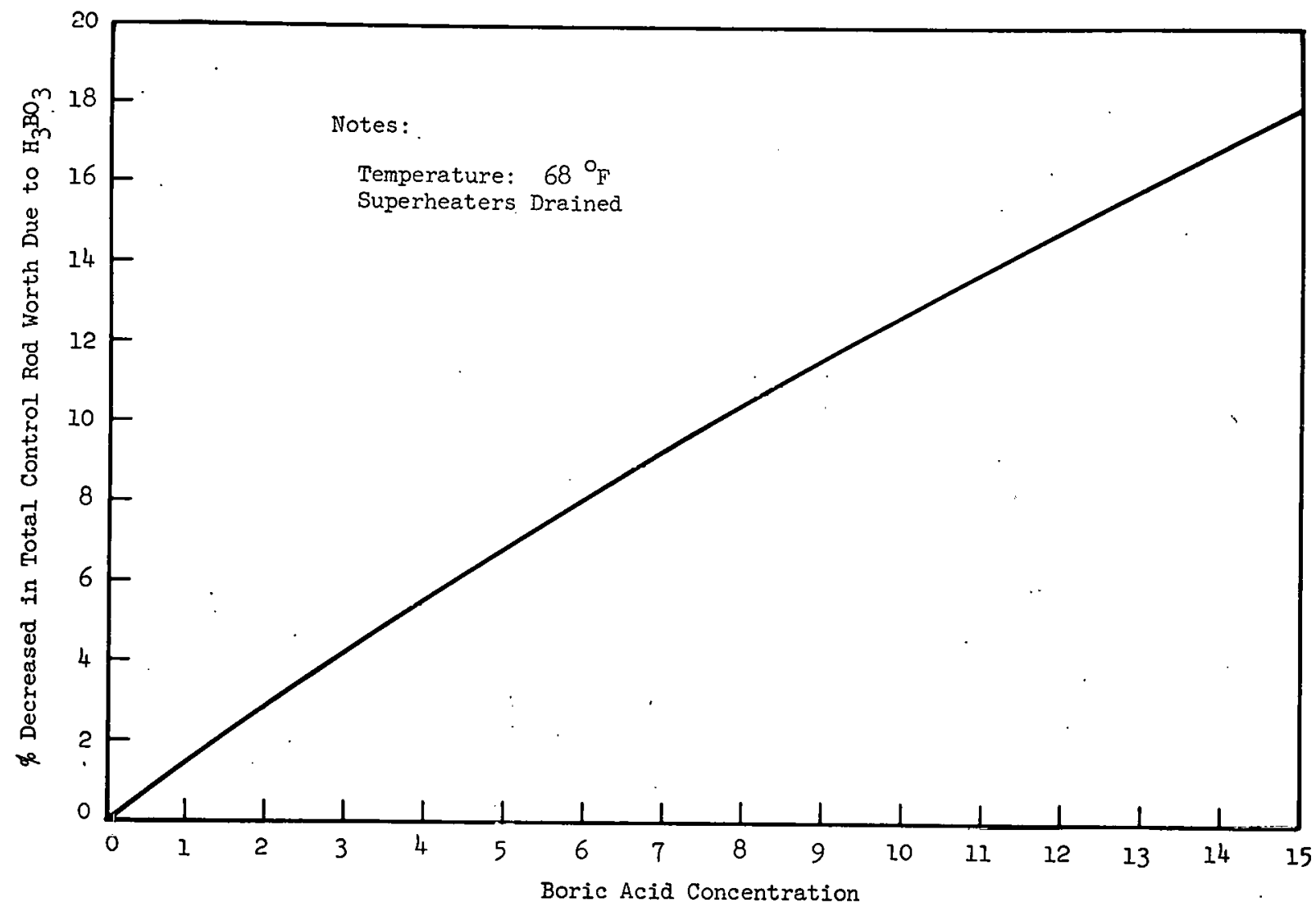

ID-103-A3516

Fig. 28. Calculated Fractional Decrease in Control-rod Worth as a Function of Boric Acid Concentration, Core PSH-1 
curve could be used as a basis for correcting the measured control-rod worths for the boric acid defect in the following manner:

Assume that the point-to-average rod worth is not changed by boric acid, and that the calculated values of total control-rod worth are correct. The point-to-average rod worth can be obtained by dividing the measured worth at any point by the average worth corresponding to the boric acid concentration at that measured point. The true rod worth is obtained by multiplying the point-to-average value by the average rod worth with no boric acid.

Subsequent calculations indicated that while the lotal controlrod worth (full in to full out) decreases appreciably with increasing boric acid concentration, the effect is not uniform over the range of control-rod travel. In fact, calculations indicated that over the range of the measurements there is no appreciable effect. These calculations were one-dimensional, slab-geometry, diffusion-theory, flux-synthesis type, using the homogenized, four-group, fuel-region constants and group-dependent radial bucklings from the appropriate $P D Q$ problem output for the rodded and unrodded portions of the core, and with a water reflector at each end. Values of $\mathrm{k}_{\text {eff }}$ were computed for various control-rod positions from full in to full out by increasing the thickness of the unrodded region and decreasing the thickness of the rodded region while maintaining a total core height of 24 in. The bucklings of the adjacent core region were used in each of the two reflector regions. The resulting values of $k_{\text {eff }}$ are listed in Table XV. The homogenized constants and bucklings are given in Appendix $F$.

TABLE XV. Calculated $k_{\text {eff }}$ as a Function of Control-rod Position for Various Boric Acid Concentrations, Core PSH-1

\begin{tabular}{ccccc}
\hline $\begin{array}{c}\text { Control-rod Position, } \\
\text { from Bottom of Core, in. }\end{array}$ & \multicolumn{3}{c}{ Boric Acid Concentration, $\left.g\left(\mathrm{H}_{3} \mathrm{BO}_{3}\right) / \mathrm{gal}_{(\mathrm{H}} \mathrm{O}\right)$} \\
\cline { 2 - 5 } 0 & 0 & 5 & 10 & 15 \\
\hline 1 & 0.8841 & 0.8527 & 0.8253 & 0.8018 \\
2 & 0.8902 & - & 0.8283 & 0.8042 \\
3 & 0.9004 & 0.8634 & 0.8337 & 0.8086 \\
4 & 0.9168 & 0.8751 & 0.8433 & 0.8167 \\
5 & 0.9374 & 0.8914 & 0.8577 & 0.8292 \\
5.5 & 0.9587 & 0.9100 & 0.8750 & 0.8448 \\
6 & 0.9688 & 0.9194 & 0.8840 & 0.8531 \\
6.5 & 0.9786 & 0.9285 & 0.8929 & 0.8615 \\
7 & 0.9877 & 0.9372 & 0.9015 & 0.8696 \\
7.5 & 0.9964 & 0.9455 & 0.9098 & 0.8775 \\
8 & 1.0045 & 0.9534 & 0.9176 & 0.8851 \\
9 & 1.0120 & 0.9609 & 0.9251 & 0.8922 \\
10 & 1.0257 & 0.9744 & 0.9386 & 0.9054 \\
12 & 1.0375 & 0.9862 & 0.9506 & 0.9171 \\
14 & 1.0569 & 1.0057 & 0.9704 & 0.9364 \\
16 & 1.0719 & 1.0208 & 0.9856 & 0.9513 \\
18 & 1.0836 & 1.0327 & 0.9976 & 0.9630 \\
20 & 1.0929 & 1.0420 & 1.0069 & 0.9722 \\
24 & 1004 & 1.0494 & 1.0143 & 0.9793 \\
\hline & 1.1129 & 1.0493 & 0.9243 & 0.9885 \\
\hline
\end{tabular}


Derivatives of $k_{\text {eff }}$ with respect to height were obtained from these values, and the results are shown in Fig. 29. The resulting curves thus indicate that the total control-rod worth is decreased by increasing. boric acid concentration, and that the position of the peak worth is shifted slightly toward the core center line, which was, of course, expected. The curves also indicate that there is no appreciable change in the control-rod worth above $\sim 9$ in.

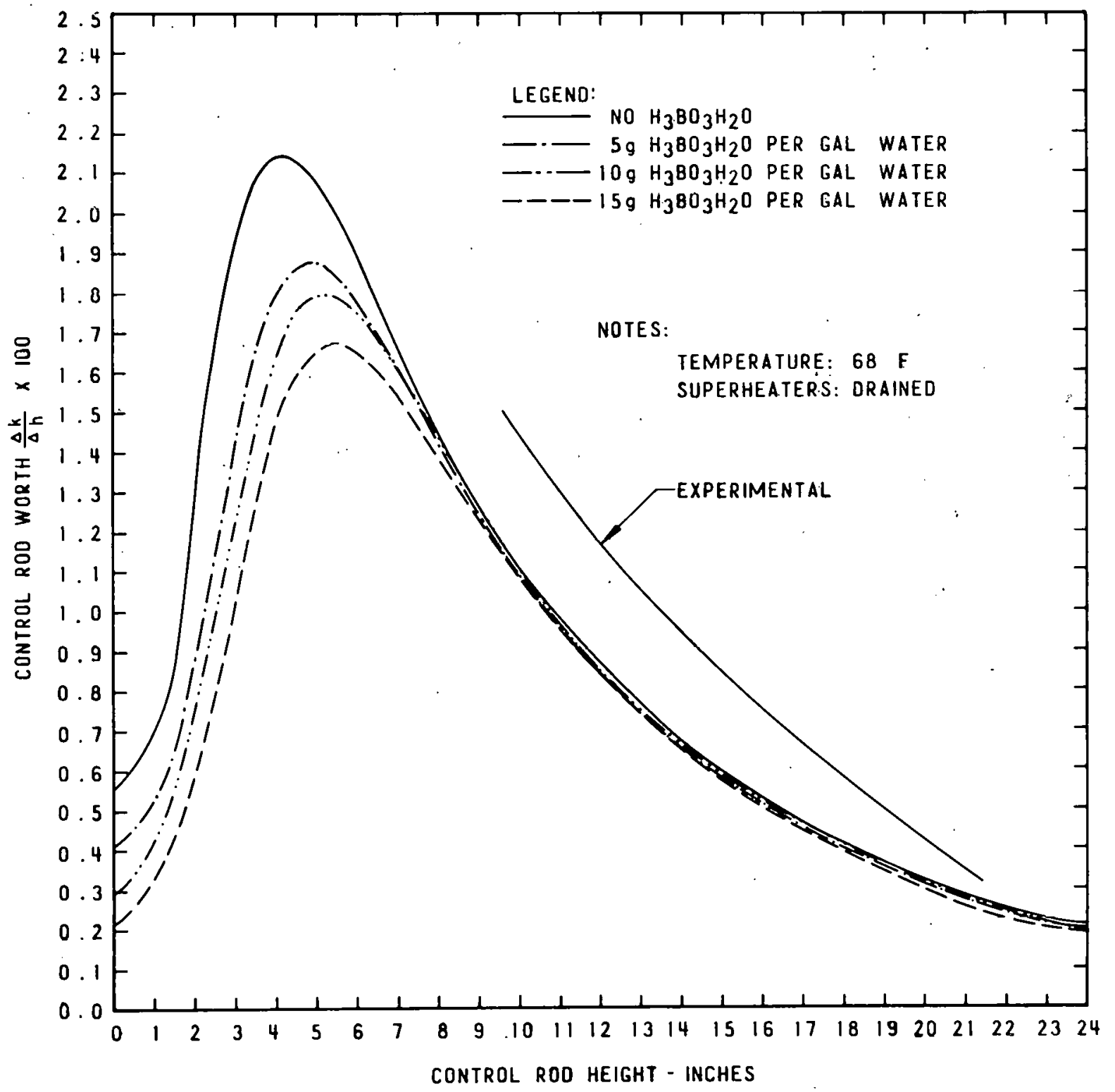

ID-103-A 3528

Fig. 29. Nine-control-rod Bank, Calculated Differential Worth, Core $\mathrm{PSH}-1$

The measured values of control-rod worth are also shown in Fig. 29 for comparison, and they indicate that the calculated values are far from absolute agreement. It is expected that if an iterative process 
were employed (as in the flux-synthesis technique) to converge on groupand region-dependent radial bucklings, and if the axial reflector regions were treated as accurately as possible, much better agreement would be obtained. It might be implied that since the calculated control-rod worths are considerably less than the measurements, the overall control-rod worth has been grossly underestimated in the calculations, and thus the reactor was considerably more subcritical with the control rods fully inserted than had been previously estimated.

\section{Flooding Worth}

The flooding worth, i.e., the reactivity effect of flooding the superheaters, was calculated to be $1.20 \% \Delta \mathrm{k}$ at room temperature and $1.28 \% \Delta \mathrm{k}$ at $489^{\circ} \mathrm{F}$. These can be compared to the "safety coefficient of flooding" as determined from experiment by multiplying the change in control-rod critical position by the average of the rod worth at two positions. This "safety coefficient" was determined to be $1.66 \% \Delta \mathrm{k}$ at room temperature and $1.30 \% \Delta \mathrm{k}$ at $489^{\circ} \mathrm{F}$. Thus, while the actual reactivity effect of flooding the superheaters increases slightly with temperature, the "safety coefficient" decreases with temperature. Examination shows that the "safety coefficient" is greater than the change in $k$ (in the case of core PSH-1, at least) by the area between the two curves of control-rod worth. This is illustrated in Fig. 30, where curve A represents the floodedsuperheater case and $B$ represents the curve of control-rod worth with

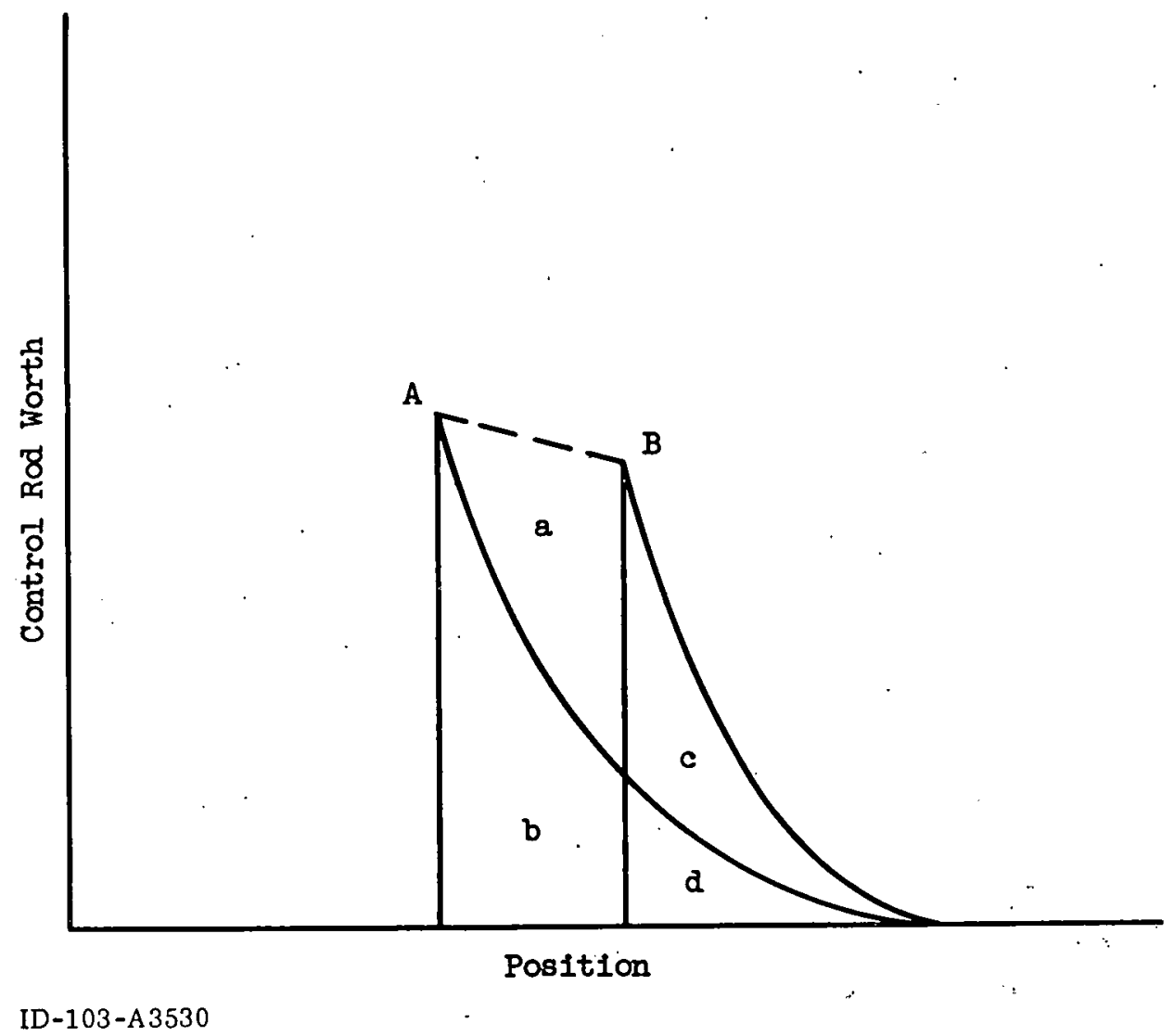

Fig. 30. Comparison of Experimental and Calculated Changes in Reactivity 
superheaters drained. : The reactivity effect of flooding would be the area under curve $B$ subtracted from the area under curve $A$, or

Flooding worth $=(b+d)-(c+d)=b-c$.

The "safety coefficient of flooding" is simply $a+b$. The difference between the "safety coefficient" and the reactivity flooding worth is

$(a+b)-(b-c)=a+c$

3. Temperature Coefficient

The temperature coefficient as a function of temperature was determined in core PSH-1, with the superheaters flooded, by observing the critical control-rod position as a function of temperature and assuming that the control-rod calibration curve at room temperature held for all temperatures. Referring to Table XII, one sees that the calculated keff is decreased by 0.0450 in going from 68 to $489^{\circ} \mathrm{F}$ with superheaters drained. This gives an average temperature coefficient of $-1.07 \times 10^{-4} \Delta \mathrm{k} /{ }^{\circ} \mathrm{F}$.

With the superheaters flooded, $k_{\text {eff }}$ is decreased by 0.0168 in going from 68 to $300^{\circ} \mathrm{F}$, and by 0.0274 from 300 to $489^{\circ} \mathrm{F}$. Thus, the average temperature coefficient from 68 to $300^{\circ} \mathrm{F}$ is $-0.72 \times 10^{-4} \Delta \mathrm{k} /{ }^{\circ} \mathrm{F}$; and from 300 to $489^{\circ} \mathrm{F}$, the average temperature coefficient is $-1.45 \times 10^{-4}$ $\Delta \mathrm{k} /{ }^{\circ} \mathrm{F}$. The average from 68 to $489^{\circ} \mathrm{F}$ is $-1.05 \times 10^{-4} \Delta \mathrm{k} /{ }^{\circ} \mathrm{F}$ with superheaters flooded. These values are plotted in Fig. 31 as a function of temperature, along with some experimentally determined values. The agreement is good, especially since the room-temperature rod-worth curve as a function of position was used for all temperatures, and it is known that the control-rod worth increases with temperature. As a result, the experimentally determined values are too large in magnitude, the error becoming larger with increasing temperature.

\section{Power Coefficient}

If the assumption is made that the normalization on calculated $k_{\text {eff }}$ for $68^{\circ} \mathrm{F}$, drained, holds for the $489^{\circ} \mathrm{F}$ case (that is, adding 0.0145 to calculated $\mathrm{k}$ ) then $\mathrm{k}_{\text {eff }}$ at $489^{\circ} \mathrm{F}$ with superheaters drained is 1.0700 . The maximum power obtained in core PSH-1, before fission-product poisons built in and without cooling the inlet water, was about $20 \mathrm{MWt}$. Thus, the average power coefficient of reactivity was about $-0.0035 \Delta \mathrm{k} / \mathrm{MWt}$ from 0 to $20 \mathrm{MWt}$.

Again assuming that adding 0.0145 to the calculated $\mathrm{k}_{\text {eff }}$ holds for the PDQ problem representing power operation with $10 \%$ voids in the boiler fuel-region coolant, and boiler fuel temperature at $900^{\circ} \mathrm{F}, \mathrm{k}_{\mathrm{eff}}$ for this situation would be 1.0413 . If it is assumed that the power coefficient 
is a lineàr function of void fraction in the boiler fuel-region coolant, this implies that at full power of $20 \mathrm{MW}$ the average void fraction in the $3.375-$ in.-sq boiler fuel region is about $25 \%$.

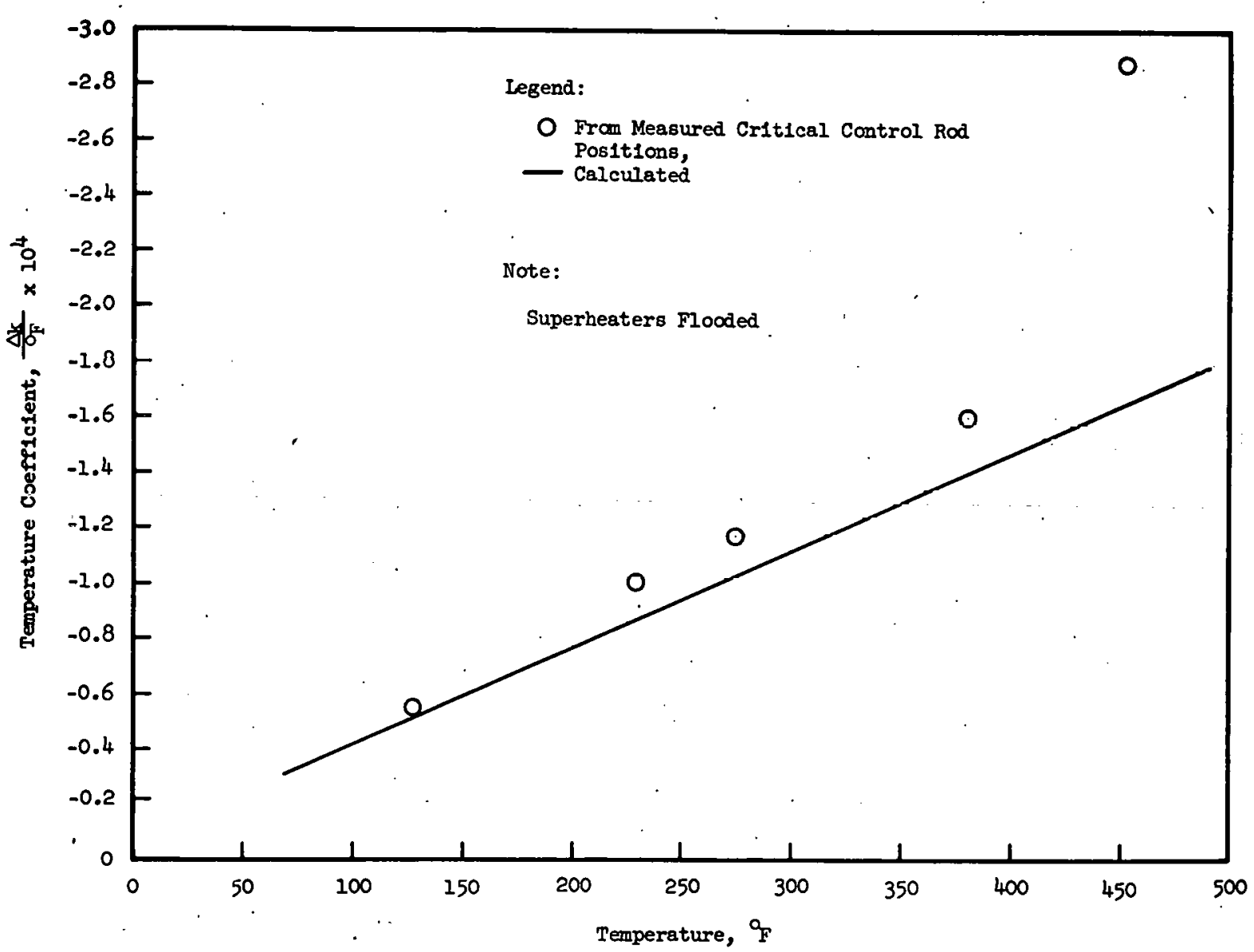

ID-103-A3515

Fig. 31. Temperature Coefficient, Core PSH-1

C. Neutron-flux Measurements*

A rather extensive program of experimental flux mapping was carried out on the various cores of BORAX-V. The measurements included coarse flux distributions, fine power distributions, and cadmium ratio measurements. Some of the results are presented here; additional results as well as methods and procedures are presented in Refs. 28, 37 , 38 , and 39 .

\section{Fine-power Distribution}

Normalized fine-power distributions for the various cores are shown in Figs. 32, 33, 34, and 35. These data were obtained at zero power and room temperature by irradiating flux wires of uranium (235)-aluminum and uranium (235)-zirconium.

*This section written by D. C. Cutforth, Idaho Division. 


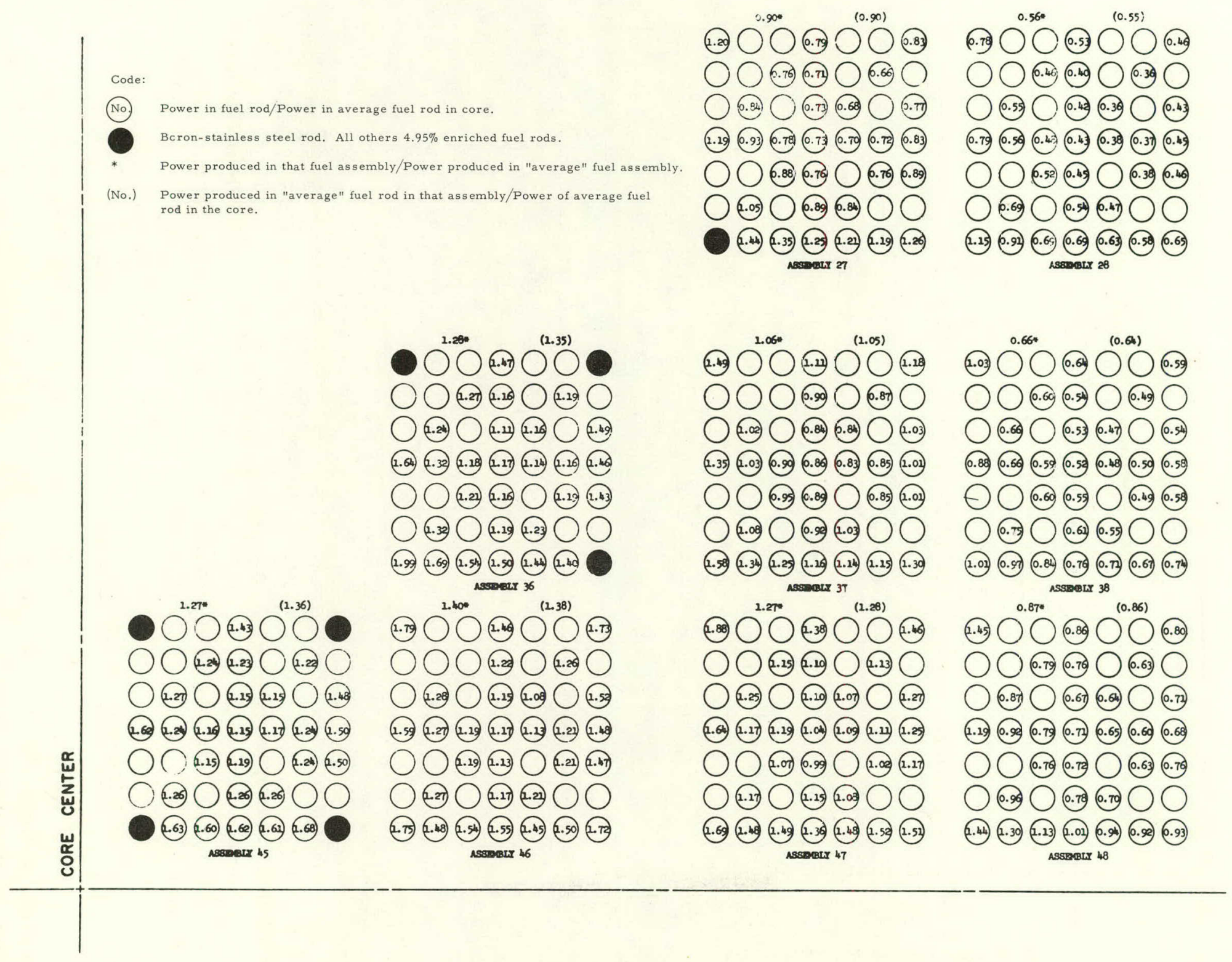




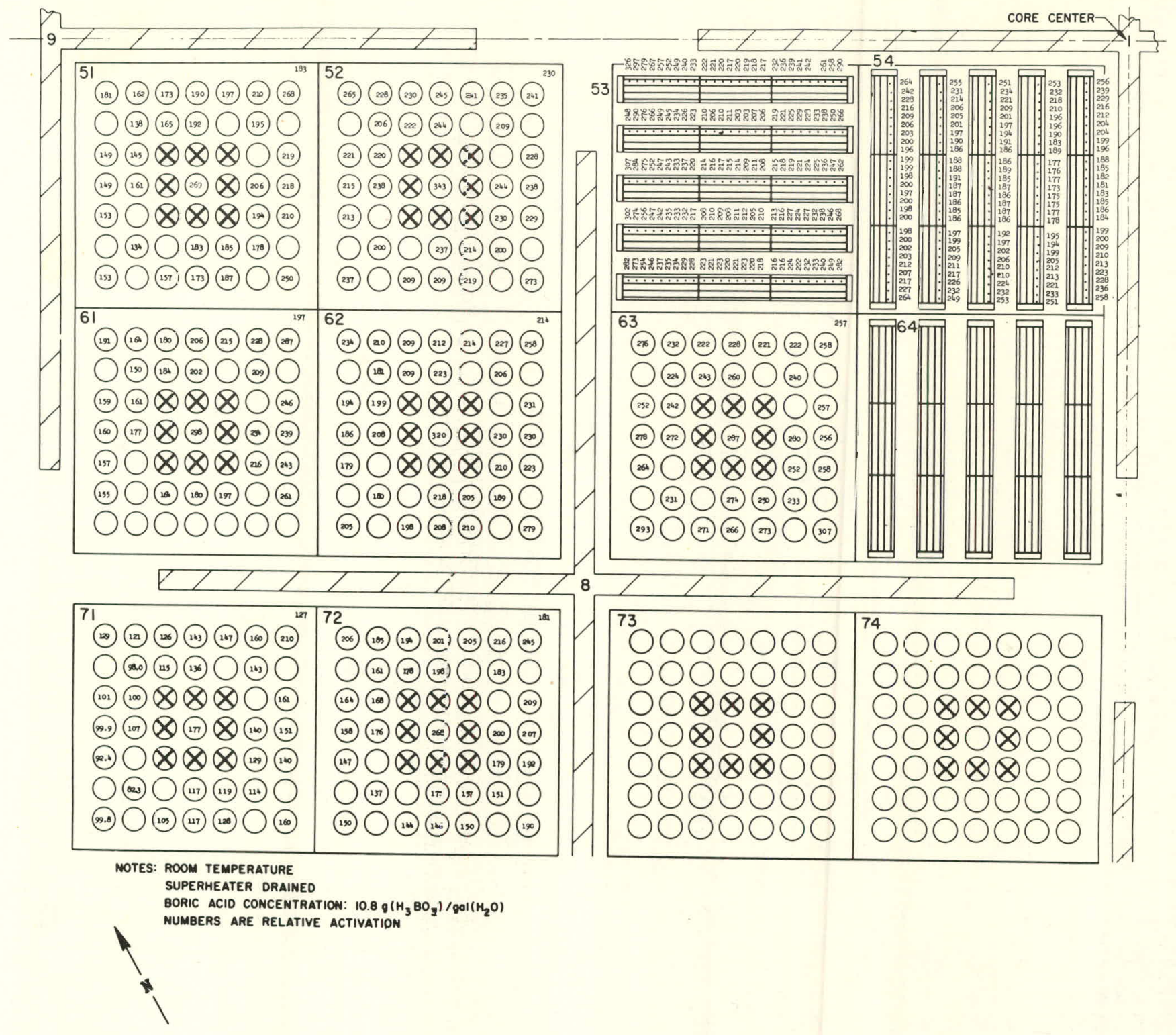

ID-103-A3270 Fig. 33. Final Normalized Fine-power Map, Core CSH-1 


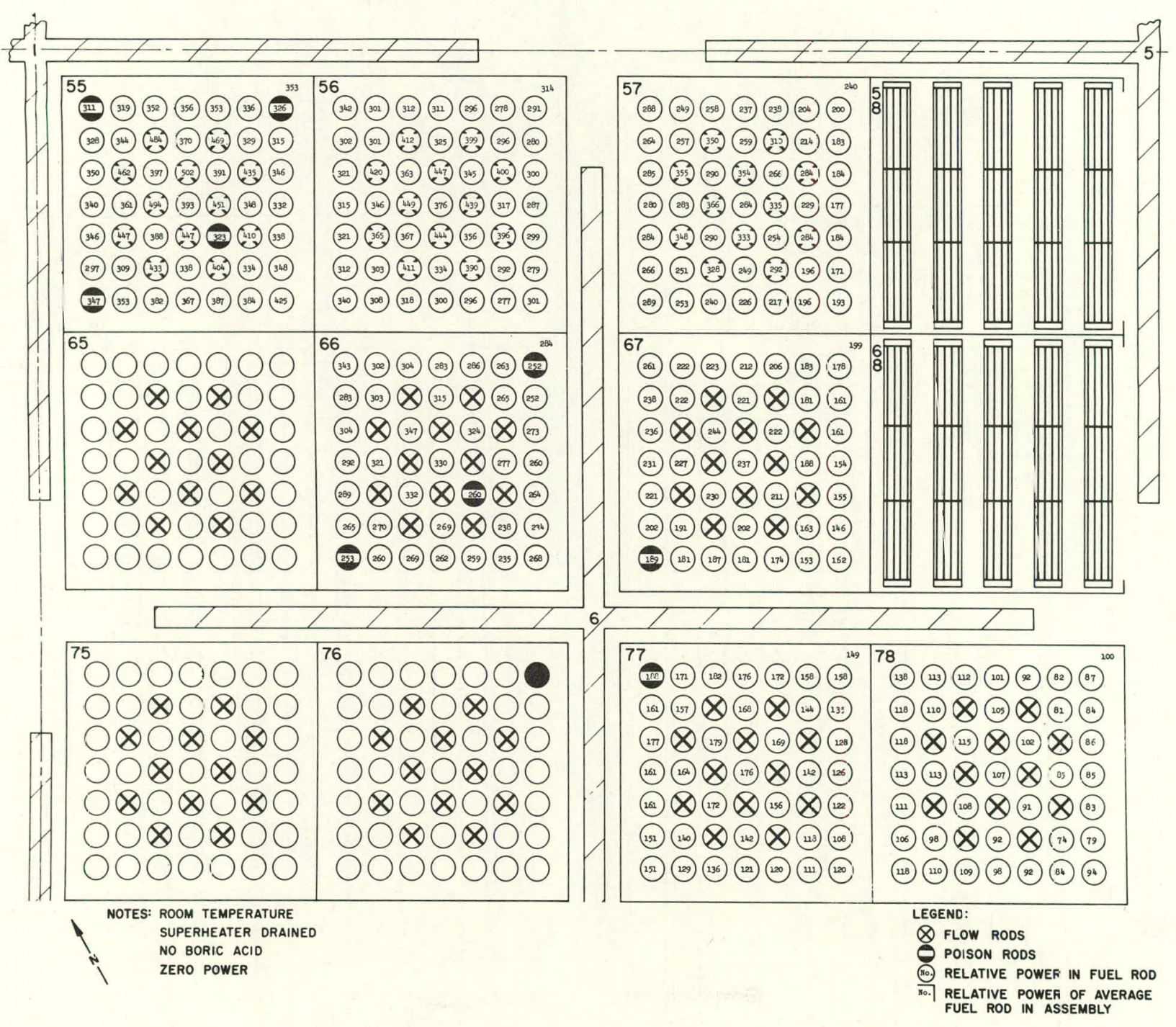

ID-103-A3527

Fig. 34. Normalized Boiler-region Fine-flux Map, Core PSH-1 

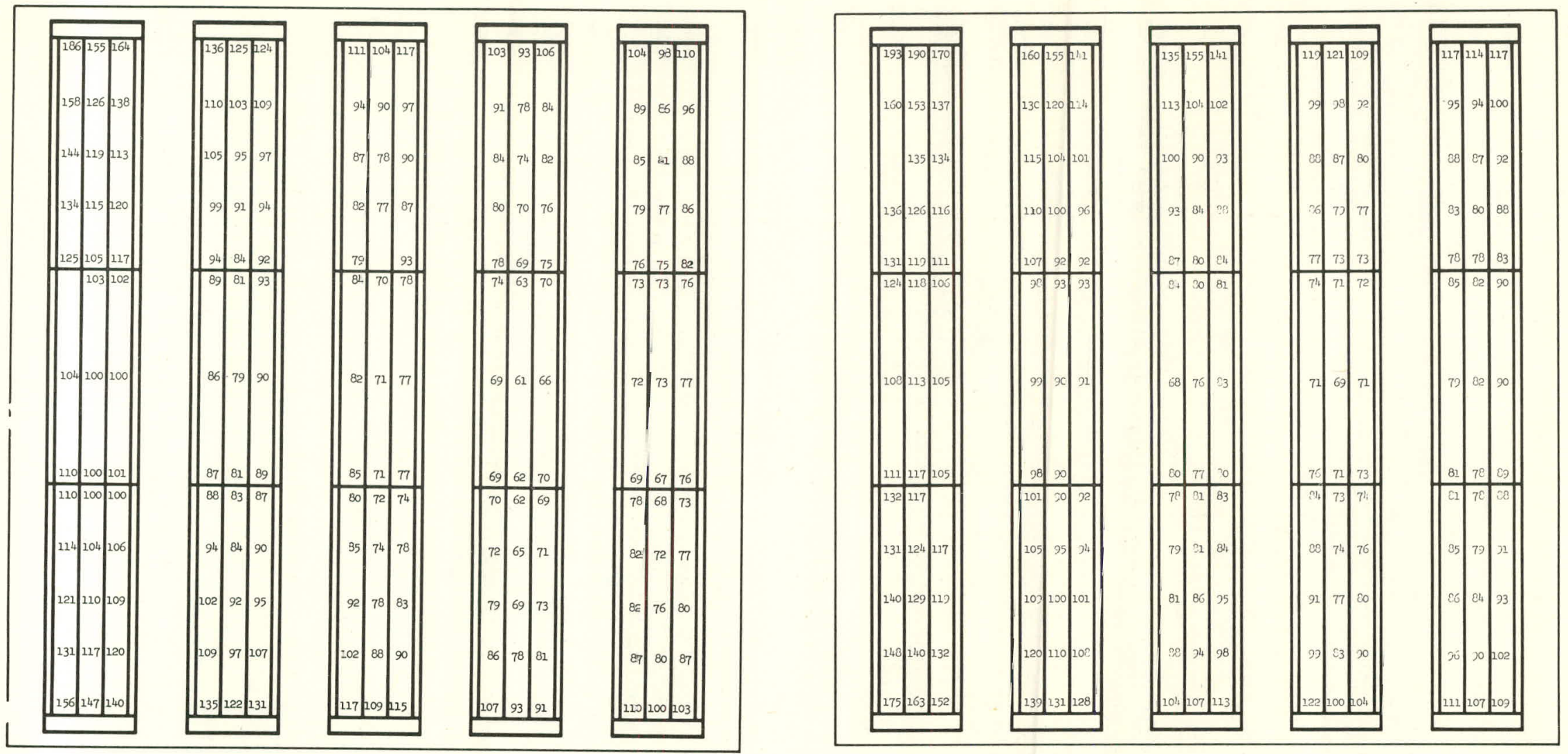

NOTES: ROOM TEMPERATURE SUPERHEATER DRAINED

NO BORIC ACID

ZERO POWER

NUMBERS ARE RELATIVE POWER

NOTES: ROOM TEMPERATURE SUPERHEATER DRAINED

NO BORIC ACID

ZERO POWER

NUMBERS ARE RELATIVE POWER

103-A3533 \& A3526

Fig. 35. Normalized Superheater-region Fine-flux Map 
Similar measurements could not be made at operating conditions because of the blockage of coolant channels during the irradiation. Measurements were made in one octant of the core on the assumption that symmetry existed. The existence of symmetry was verified in core B-l by special traverse measurements. ${ }^{28}$

Figure 36 shows the experimental results of the effect of various flow-rod configurations on the power distribution within a boiling fuel. assembly. These results compare favorably with calculations (see Fig. 19). Proper replacement of the fuel rods with flow rods reduced the peak-toaverage power production within a fuel assembly, as shown in Table XVI.

TABLE XVI. Effect of Flow Rods on Power Distribution within Boiling Fuel Assemblies

\begin{tabular}{cc}
\hline No. of Flow Rods & $\begin{array}{c}\text { Individual Fuel-rod } \\
\text { Peak-to-average } \\
\text { Power Production }\end{array}$ \\
\hline 0 & 1.47 \\
4 & 1.27 \\
8 & 1.51 \\
12 & 1.20 \\
\hline
\end{tabular}

2. Axial.Flux Distributions

Axial neutron-flux distribution measurements were made in each core at various power levels. From these measurements, axial flux shapes, axial peak-toaverage ratios, and axial bucklings were obtained. The measurements were obtained from gold-wire irradiations in the earlier cores, and from $\mathrm{Al}-1 \% \mathrm{Cu}$ wire and miniature fission ion chambers in the peripheral superheater core.

Figure 37 shows axial neutron-flux distributions for power levels of $0.5,5,10,15$, and $20 \mathrm{MWt}$. Note that the axial position of the peak activation shifts downward with increasing power level. A comparison of these data with those obtained from the $\mathrm{U}^{235}$-loaded.ion chambers showed excellent agreement.

Experimental axial bucklings were obtained from a least-squares cosine-curve fit. In this fit, only those data that had the appearance of not being influenced by either the control rods or the reflector were used. Several axial bucklings are presented in Table XVII.

A maximum fission-causing flux of $2 \pm 0.2 \times 10^{13}$ at $18.4 \mathrm{MWt}$ was obtained by using the chamber sensitivity from the manufacturer. This value was not corrected for the flux depression caused by the thimble or the local depression caused by the absorption of the miniature ion chamber. However, it compares favorably with the value of $2.97 \times 10^{13}$ obtained from $P D Q$ calculations. 


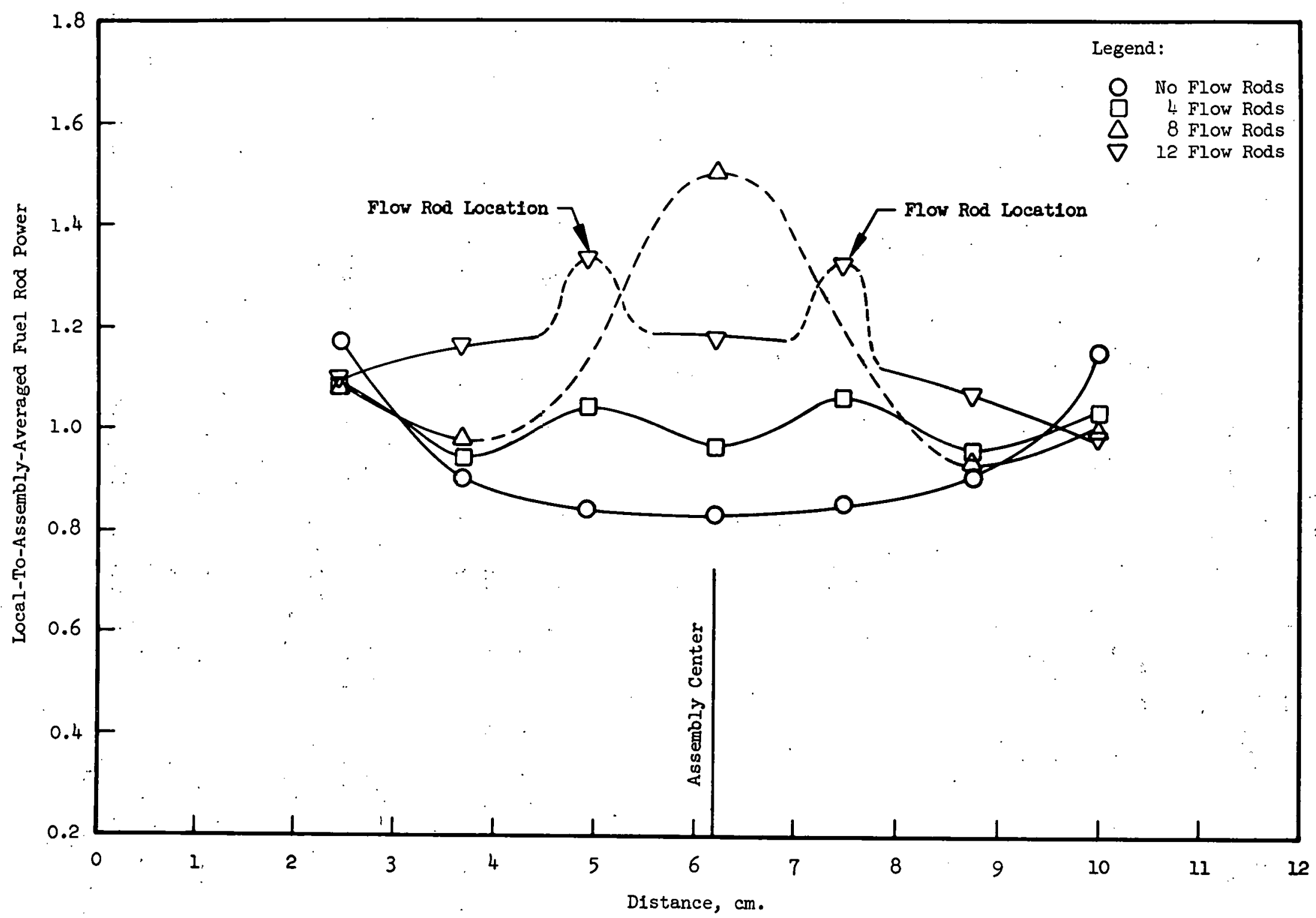

ID-103-A3508

Fig. 36. Fine-flux Traverse through a Boiling Assembly with Various Metal-to-Water Ratios 


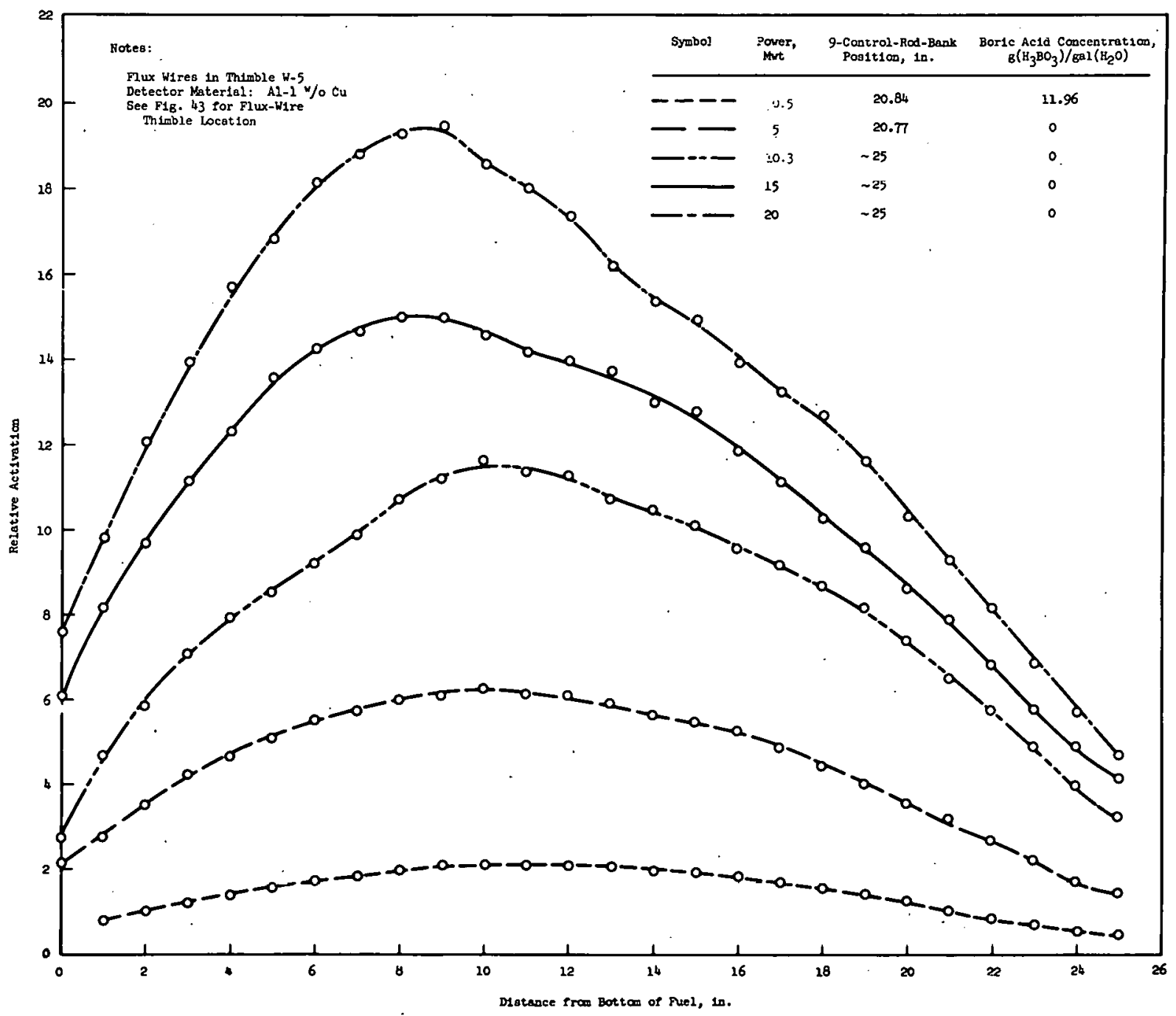

ID-103-A3415

Fig. 37. Axial Neutron-flux Distributions at Power, Core Position 43, Core PSH-1A 
TABLE XVII. Experimental Axial Bucklings

\begin{tabular}{|c|c|c|c|c|}
\hline Core Position & $\begin{array}{l}\text { Control-rod } \\
\text { Position, } \\
\text { in. }\end{array}$ & $\begin{array}{c}\text { Boric Acid } \\
\text { Concentration, } \\
\mathrm{g}\left(\mathrm{H}_{3} \mathrm{BO}_{3}\right) / \mathrm{gal}\left(\mathrm{H}_{2} \mathrm{O}\right)\end{array}$ & $\begin{array}{c}\text { Power Level, } \\
\mathrm{MWt}\end{array}$ & $\mathrm{B}^{2}, \mathrm{~cm}^{-2}$ \\
\hline $55 \mathrm{PSH}$ & 9.6 & 0 & 0.5 & 0.00362 \\
\hline $66 \mathrm{PSH}$ & 9.6 & 0 & 0.5 & 0.00343 \\
\hline $77 \mathrm{PSH}$ & 9.6 & 0 & 0.5 & 0.00422 \\
\hline $44 \mathrm{PSH}$ & 14.1 & 0 & 0.5 & 0.00318 \\
\hline $43 \mathrm{PSH}$ & 14.1 & 0 & 0.5 & 0.00263 \\
\hline $42 \mathrm{PSH}$ & 14.1 & 0 & 0.5 & 0.00236 \\
\hline $22 \mathrm{PSH}$ & 14.1 & 0 & $0.5^{\circ}$ & 0.00268 \\
\hline $41 \mathrm{PSH}$ & 14.1 & 0 & 0.5 & 0.00289 \\
\hline $41 \mathrm{PSH}$ & 25.0 & 0 & 15 & 0.00209 \\
\hline $42 \mathrm{PSH}$ & 25.0 & $\dot{0}$ & 15 & $0.00186^{\circ}$ \\
\hline $43 \mathrm{PSH}$ & 25.0 & 0 & 15 & 0.00130 \\
\hline $44 \mathrm{PSH}$ & 25.0 & .0 & 15 & 0.00099 \\
\hline $36 \mathrm{PSH}$ & 25.0 & 0 & 22.4 & 0.00135 \\
\hline $36 \mathrm{PSH}$ & 2.5 .0 & 0 & 18.4 & 0.00145 \\
\hline $36 \mathrm{PSH}$ & 25.0 & 0 & 15.4 & 0.00148 \\
\hline $36 \mathrm{PSH}$ & 25.0 & 0 & 12.4 & 0.00138 \\
\hline 36 PSH & 25.0 & 0 & 10 & 0.00117 \\
\hline $36 \mathrm{PSH}$ & 19.5 & 0 & 4.5 & 0.00165 \\
\hline $36 \mathrm{PSH}$ & 20.5 & 0 & 4 & 0.00170 \\
\hline $22 \mathrm{PSH}$ & 20.6 & 11.96 & 0.5 & 0.00184 \\
\hline $41 \mathrm{PSH}$ & 20.6 & 11.96 & 0.5 & 0.00203 \\
\hline $42 \mathrm{PSH}$ & 20.6 & 11.96 & 0.5 & 0.00189 \\
\hline $43 \mathrm{PSH}$ & 20.6 & 11.96 & 0.5 & 0.00195 \\
\hline $44 \mathrm{PSH}$ & 20.6 & 11.96 & 0.5 & 0.00184 \\
\hline
\end{tabular}

\section{Cadmium Ratios}

Figures 38 and 39 show the axial cadmium-ratio variation in the pressure thimbles for power levels of 5 and $15 \mathrm{MWt}$ in $\mathrm{PSH}-1$. In these figures, cadmium ratios from miniature ion chambers can be compared with cadmium ratios from flux wires. Both sets of data show similar trends, with a much smaller axial variation than was anticipated. The data indicate that approximately the same degree of thermalization occurs throughout the axial traverse of the core. The value of the cadmium ratio decreased with increasing power. 


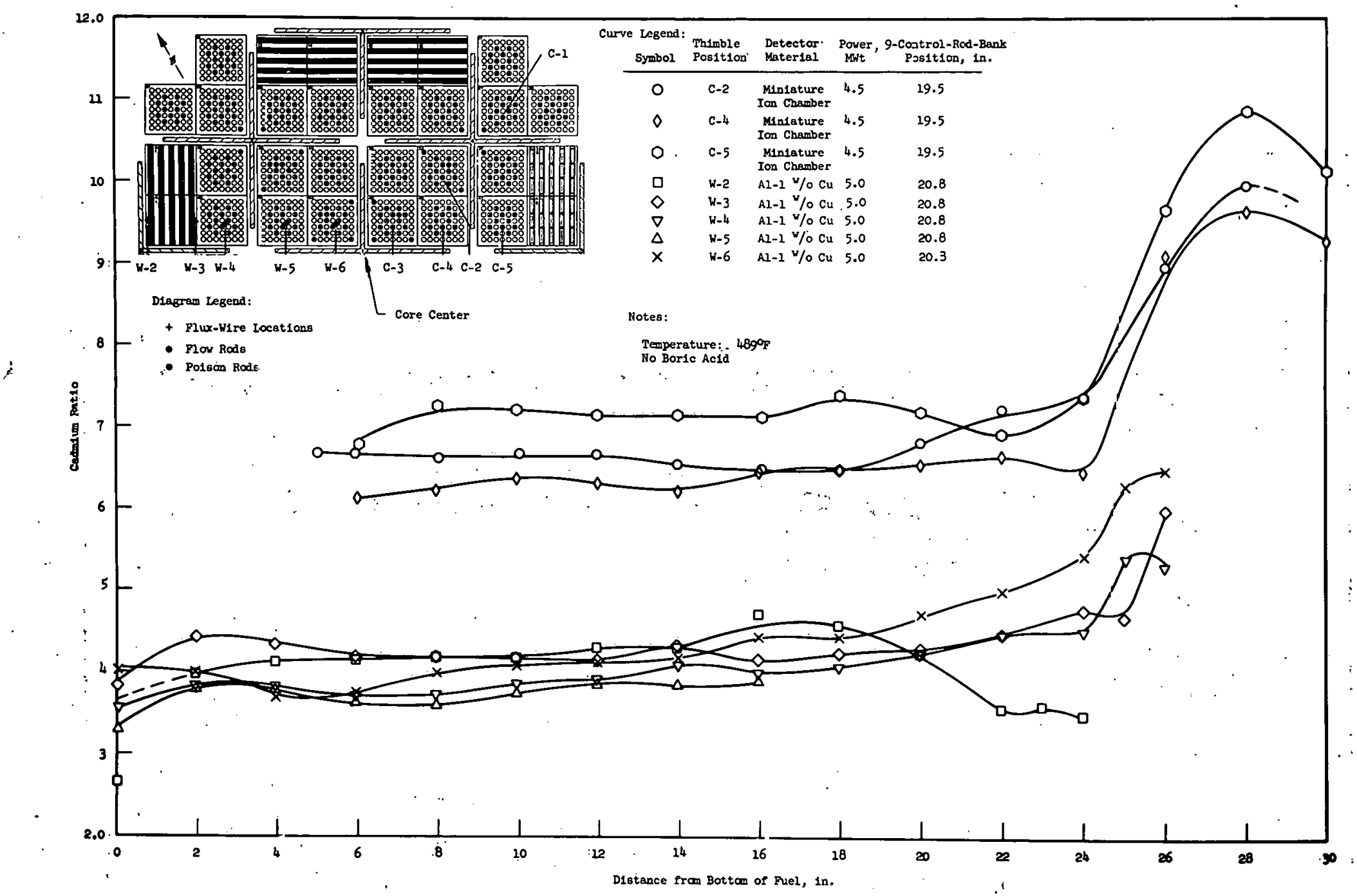

ID $-103-A 3518$

Fig. 38. Cadmium-ratio Distributions at $5 \mathrm{MWt}$, Cores PSH-1 A and C 


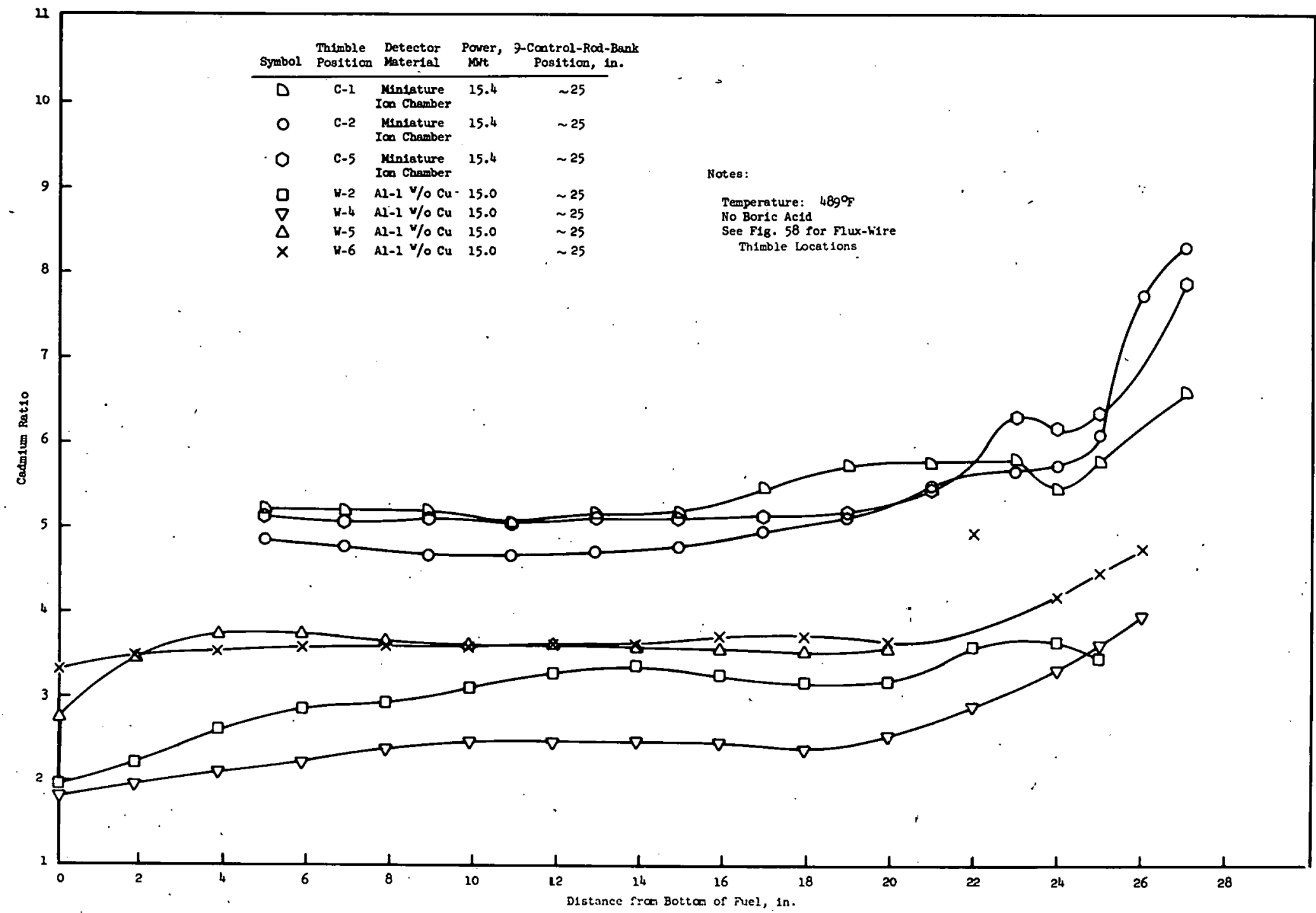

ID $-103-A 3453$

Fig. 39. Cadmium-ratio Distributions at $15 \mathrm{MWt}$, Cores PSH-1 A and C 


\section{MISCELLANEOUS TOPICS}

A. Approximations in Few-group Reactor-physics Calculations*

Methods of reactor-physics analysis used in the design calculations of BORAX-V reactors have been previously outlined in Sections III-B and III-D. Specifically, the MUFT program with its as sociated library of cross sections was used to compute diffusion-theory parameters for one, two, or three collapsed-energy groups of above-thermal neutrons. The SOFOCATE program was applied to the computation of diffusion-theory parameters for a single group of thermal neutrons.

In MUFT computations for BORAX-V analysis, the option of the socalled "conventional Selengut-Goertzel (S-G)" model of neutron slowing down had been selected. For small bucklings, $\mathrm{B}^{2} \approx 0$, the computed value of $k_{e f f}\left(B^{2}\right)$ decreases more rapidly than it would if the few-group parameters were obtained from the alternative model option, "consistent $P_{1}$; no S-G." In the case of the 60-fuel-assembly reference boiler core, the difference in reactivity is approximately $1 \%$ at room temperature.

Strictly, the few-group parameters obtained from MUFT and SOFOCATE computations are associated with a single value of the buckling, namely, the value of the buckling $\left(B_{\text {input }}^{2}\right.$ ) assigned as input. However, often it is desirable to compute the effective multiplication factor, $k_{e f f}\left(B^{2}\right)$, for other values of the buckling, without recomputing the few-group parameters in each case. Wick ${ }^{40}$ has reported on numerical studies of the sign and the magnitude of the errors in $k_{e f f}\left(B^{2}\right)$ resulting from the use of a bucklingindependent, fixed set of few-group parameters. These computations were made for some special cases of thermal reactors. Similar computations have been performed for several BORAX-V lattices. For $B_{\text {input }_{1}}^{2}=$ $0.0035 \mathrm{~cm}^{-2}$, and $B_{\text {input }}^{2} \approx 0.015 \mathrm{~cm}^{-2}$, four-group fundamental-mode computations yielded the inequality

$$
k_{\text {eff }}\left(B^{2} ; B_{\text {input }}^{2}\right) \geqq k_{\text {eff }}\left(B^{2} ; B_{\text {input }_{2}}^{2}\right)
$$

between 0 and $0.02 \mathrm{~cm}^{-2}$. Using the properties of the continuity and monotonicity of $k_{e f f}\left(B^{2}\right)$ as a function of $B^{2}$, we conjecture that $k_{\text {eff }}\left(B^{2}\right.$; $\left.B_{\text {input }}^{2}\right)$ is bounded by these two functions within that same buckling interval.

The above-mentioned inequality appears to be due largely to a decrease in $\Sigma_{\mathrm{a}} / \Sigma_{\text {rem }}$ in the collapsed group covering the range of resonance energies in $U^{238}$, group 3 , at the lower value of $B_{\text {input }}^{2}$ In the vicinity of $\mathrm{B}^{2}=0.0035 \mathrm{~cm}^{-2}$, the difference in $\mathrm{k}_{\text {eff }}$ is $\approx 0.9 \%$, where the "difference" is. defined to be

$$
k_{\text {eff }}\left(B^{2} ; B_{\text {input }}^{2}\right)-k_{\text {eff }}\left(B^{2} ; B_{\text {input }}^{2}\right)
$$

* Memorandum from D. H. Sháftmän, RE Division, to R. E. Rice, October 29, 1962. 
The procedures used in the MUFT program to collapse the 54 neutronenergy groups to three groups, two groups, or one group are consistent in the sense that the computed absorption rate, fission rate, probability of slowing down to thermal energies, etc., per source neutron are the same in all three few-group calculations, provided $B^{2}=B_{M U F T}^{2}$ input. In computations of BORAX-V lattices, the two-group and four-group values of $k_{e f f}\left(B^{2}\right)$ obtained on the basis of $B_{\text {input }}^{2} \approx 0$ were greatly different (of the order of $4 \%$ ) for $\mathrm{B}^{2} \approx 0.015 \mathrm{~cm}^{-2}$, and as would be expected, were quite close for bucklings near zero. Indeed, as $B^{2} \rightarrow 0$, the values of $k_{e f f}\left(B^{2}\right)$ tended to the same number regardless of the choice of $B_{\text {input }}^{2}$ or whether the computations were by two-group or four-group diffusion theory. The reason for this is that, at least in the few-group structure selected for these analyses, the probability that a given neutron capture would be parasitic was not much affected by the details of the neutron-flux spectrum. It was for bucklings in the middle of the range between 0 and $B_{\text {input }}^{2}=0.015 \mathrm{~cm}^{-2}$ that the corresponding four-group and two-group computations showed the greatest differences in $k_{e f f}\left(B^{2}\right)$. These computations clearly indicated that if $k_{e f f}$ computations are to be performed with a single set of diffusion-theory parameters, it would be less inconsistent to do the four-group analysis than the two-group analysis for $B^{2}$ much different from the input buckling.

B. Superheater-Boiler Coupling*

\section{Effective Buckling Calculation}

The provocation to examine coupling theory in connection with the BORAX-V reactor originated as a result of questions concerning the proper buckling to give as MUFT input for the regionwise fast cross sections. Since the total buckling for a multiregion system (bare reactor) can be represented as the sum of the bucklings of the separate regions multiplied by the respective region importance functions, application of coupling theory would seem to provide a convenient method of obtaining such functions. Avery's approach ${ }^{41}$ to coupling has been usefully applied to fastthermal systems and is applicable to the BORAX-V superheating reactor.

In the design calculations, a full-core geometrical buckling of 0.0035 was used for all reactor cross-section problems. Possibly, if the calculational procedure were iterated, i.e., material bucklings were calculated from a first run on constants and weighting functions from the first reactor problems, a better estimation of bucklings appropriate for the two fuel-region compositions could be stated. Because of the uncertainties of homogenization validity, accuracy of the MUFT and SOFOCATE cross-section libraries, and a time limitation, the possibilities here indicated were not exhaustively explored.

\footnotetext{
*Study made in 1960-1961.
} 


\section{Prediction of Operational Characteristics}

Treating the superheater-boiler combination as a coupled system provides results that are at least comprehensionally useful. An interesting approach to the subject is given by Radkowsky and Bayard ${ }^{42}$ wherein the ratio of power produced between the two regions of the Pressurized Water Reactor (PWR) is calculated. The Laplacians of the diffusion equations are integrated and converted to surface integrals, thus obtaining leakages between regions.

The approach taken by Avery defines a term, $\mathrm{k}_{\mathrm{ij}}$, as the expectation value of a fission neutron in reactor $j$ creating a next-generation fission neutron in reactor i. Similarly, $S_{i j}$ is the fission-neutron source in reactor $i$ resulting from fissions caused by neutrons originating in reactor $j$. Total fission source in reactur $i$ is then

$$
S_{i}=\sum_{j=1}^{N} S_{i j}
$$

where $\mathrm{N}$ is the number of reactors in the system. For the present consideration, the following stable ratios result (B: boiling reactor; $S$ : superheating reactor):

$$
\begin{aligned}
& \frac{S_{B B}}{S_{B}}=k_{B B}, \quad \frac{S_{B S}}{S_{S}}=k_{B S} ; \\
& \frac{S_{S B}}{S_{B}}=k_{S B}, \quad \frac{S_{S S}}{S_{S}}=k_{S S} .
\end{aligned}
$$

Following Avery, other relations are obtained. If $\Delta_{i} \equiv 1-k_{i i}$, criticality is given by

$$
\mathrm{k}_{\mathrm{BS}} \mathrm{k}_{\mathrm{SB}}=\Delta_{\mathrm{B}} \Delta_{\mathrm{S}}
$$

and if $\rho$ is small compared to the $\Delta_{i}$, and $k_{e f f}=1+k_{e x}$,

$$
\mathrm{k}_{\mathrm{ex}} \approx \rho \approx \frac{\mathrm{k}_{\mathrm{BS}} \mathrm{k}_{\mathrm{SB}}-\Delta_{\mathrm{B}} \Delta_{\mathrm{S}}}{\Delta_{\mathrm{B}}+\Delta_{\mathrm{S}}}
$$

or, in terms of deviations from the critical values,

$$
\rho \approx \frac{\Delta_{\mathrm{B}} \Delta_{\mathrm{S}}}{\Delta_{\mathrm{B}}+\Delta_{\mathrm{S}}}\left(-\frac{\delta \Delta_{\mathrm{B}}}{\Delta_{\mathrm{B}}}-\frac{\delta \Delta_{\mathrm{S}}}{\Delta_{\mathrm{S}}}+\frac{\delta \mathrm{k}_{\mathrm{BS}}}{\mathrm{k}_{\mathrm{BS}}}+\frac{\delta \mathrm{k}_{\mathrm{SB}}}{\mathrm{k}_{\mathrm{SB}}}\right),
$$


and

$$
\rho \approx \sum_{i=1}^{N} \alpha_{i} \frac{\delta \nu_{i}}{\nu_{i}},
$$

where $\nu_{i}$ is the number of neutrons born per fission in reactor $i$, and $\delta \nu_{i}$ is a change in this quantity.

The fraction of reactivity in reactor $i$ is

$$
\alpha_{i}=\frac{\frac{1}{\Delta_{i}}}{\sum_{j=1}^{N} \frac{1}{\Delta_{j}}},
$$

or $\alpha_{i}$ is the ratio of overall reactivity to $\delta \nu_{i} / \nu_{i}$.

Avery's original paper discusses the kinetic equation and gives a complete formulation in terms of the adjoint and real functions.

A method* of approximating the $k_{i j}$ and the $S_{i j}$ is that of using the output sources from a typical three-region problem (superheater, boiler, and reflector) and running a second single-iteration problem where only the input source for a single fueled region is given. When this is done for each of the two regions in turn (using $R E-122$ ), values of the $S_{i j}$ are obtained and the various other expressinns may be calculated. $\Lambda$ cxample of what this means for BORAX- $V^{\prime}$ is given by the abbreviated display of $\mathrm{k}_{\mathrm{ij}}$ in Table XVIII.

\begin{tabular}{|c|c|c|c|c|c|c|c|c|c|c|}
\hline \multirow{2}{*}{$\begin{array}{c}\text { Reactor } \\
\text { Temp } \\
{ }^{\circ} \mathrm{F}\end{array}$} & \multirow[b]{2}{*}{$\begin{array}{l}\% \text { Voids } \\
\text { Boiler }\end{array}$} & \multirow[b]{2}{*}{ Superheater } & \multirow[b]{2}{*}{ Configuration } & \multirow[b]{2}{*}{$k_{e f f}$} & \multirow[b]{2}{*}{$\mathrm{k}_{\mathrm{SS}}$} & \multirow[b]{2}{*}{$\mathrm{k} S B$} & \multirow[b]{2}{*}{$\mathrm{k}_{\mathrm{BS}}$} & \multirow[b]{2}{*}{$\mathrm{k}_{\mathrm{BB}}$} & \multicolumn{2}{|c|}{$\mathrm{M}^{2}$} \\
\hline & & & & & & & & & Boiler & SH \\
\hline 489 & 15 & Dry & $\mathrm{CSH}$ & 1.010 & 0.598 & 0.094 & 0.476 & 0.901 & 76.9 & 113.5 \\
\hline 489 & 0 & Dry & $\mathrm{CSH}$ & 1.048 & 0.596 & 0.089 & 0.074 & 0.951 & 64.8 & 113.5 \\
\hline 489 & 0 & Flooded & $\mathrm{CSH}$ & 1.068 & 0.734 & 0.106 & 0.393 & 0.943 & 64.8 & 60.0 \\
\hline 70 & 0 & Dry & $\mathrm{CSH}$ & 1.130 & 0.668 & 0.087 & 0.474 & 1.041 & 47.2 & 81.7 \\
\hline 70 & 0 & Flooded & $\mathrm{CSH}$ & 1.137 & 0.791 & 0.099 & 0.363 & 1.032 & 47.2 & 41.6 \\
\hline 489 & 15 & Dry & PSH & 1.017 & 0.523 & 0.096 & 0.559 & 0.909 & 76.7 & 111.1 \\
\hline 489 & 0 & Dry & PSH & 1.057 & 0.442 & 0.100 & 0.327 & 1.004 & 64.6 & 111.1 \\
\hline 489 & 0 & Flooded & PSH & 1.067 & 0.524 & 0.122 & 0.312 & 0.998 & 64.6 & $58.8^{\circ}$ \\
\hline 70 & 0 & Dry & PSH & 1.142 & 0.468 & 0.086 & 0.345 & 1.098 & 47.0 & 80.6 \\
\hline 70 & 0 & Flooded & PSH & 1.150 & 0.580 & 0.111 & 0.321 & 1.088 & 47.0 & 41.1 \\
\hline
\end{tabular}

TABLE XVIII. Coupling Coefficients

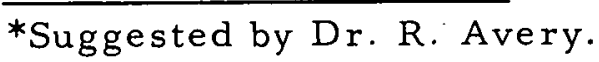


The value of the coupling approach was not fully established. A wider range of calculations would need to be performed. Consideration of what practical value may be seen here leads to such thoughts as:

a. If it was desirable, say, to increase the power fraction handled by the superheater, kSB might be expeditiously increased. An empirical dependence of this factor on the integral neutronic properties of the boiler region adjacent to the superheater could conceivably be established, and the maximizing factors determined. Comparison of the first and second examples of Table XVIII shows a slight increase in $\mathrm{ksB}_{\mathrm{SB}}$ as the CSH boiler is voided, whereas the effect is in the reverse direction (if any) for the PSH boiler voiding (sixth and seventh examples). An almost linear

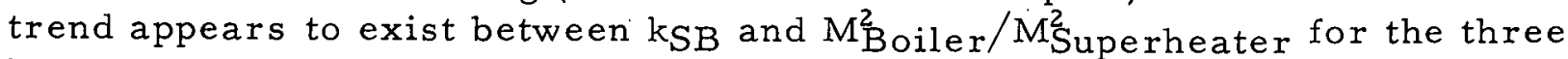
hot cases of the $\mathrm{CSH}$ core. A more realistic void distribution or the insertion of a zone adjacent to the superheater consisting of a different $\mathrm{H}_{2} \mathrm{O}: \mathrm{U}^{235}$ ratio could lead to information of practical value.

b. The construction of a model to describe the kinetic behavior of the system for the assumption of a rapid perturbation in a single region would be facilitated by thinking in terms of coupling theory.

C. A TDC Th $^{43}$ Calculation of the BORAX-V Exponential Experiment ${ }^{8}$

The exponential assembly was originally conceived as a convenient way of obtaining certain lattice measurements on BORAX-V boiler fuel. Time available for the actual experimental work was restricted because of the need to use the fuel in loading the BORAX-V reactor.

Three hundred forty-nine fuel rods were arranged in a cylinder supported so as to maintain the reference 0.5-in. spacing. Constructed in the form of three trays, the cylinder was crisscrossed with aluminum sheets to approximate the actual condition of the interassembly regions within the core. For safety reasons, the entire assembly was surrounded by cadmium sheets to cancel the effect of a radial reflector. Figure 40 reproduces a cross-sectional drawing of the assembly. Enriched $3.38 \mathrm{w} / \circ \mathrm{U}^{235}$-zirconium alloy wires, $3 / 8 \mathrm{in}$. long, were used for flux measurements.

Cadmium ratios were measured along axial and radial traverses for a variety of moderator voids, which were simulated by using a number of small-diameter pieces of polyethylene tubing closed at the ends. These were placed within the central "assembly" square only. The fact that the negative buckling had the same value, regardless of the amount of simulated void, was something of a surprise. This fact is perhaps explained by the insulating effect of the surrounding unvoided medium. 


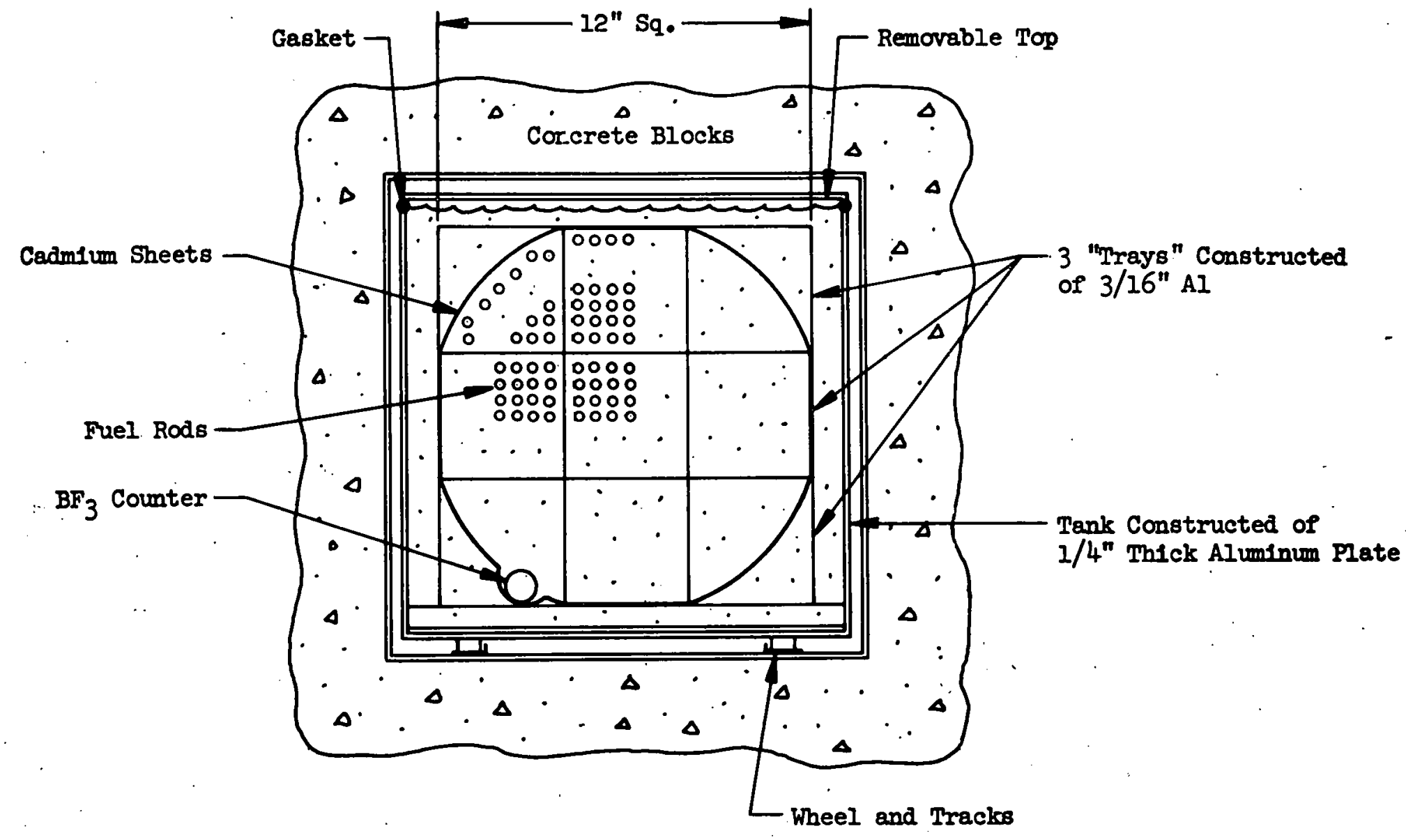

ID-103-A3523

Fig. 40. Cross Section of Exponential Assembly 
....TDC is a two-dimensional, cylindrical-geometry, transport-theory counterpart of DSN. TDC allows the specification of a source in the first axial region, which, in the representation of the BORAX-V exponential, was done by giving a source of unity in each of four groups in that region. In effect, this unit source was put into a $26-\mathrm{cm}$-thick region of water. MUFT and SOFOCATE cross sections were used in all regions, except that the radial reflector was given a cadmium thermal-absorption cross section.

Figure 41 gives the calculated thermal flux plotted from the TDC output. The $1 / \mathrm{e}$-folding length for the experiment was $17.9 \mathrm{~cm}$, and this value was retained, with or without voids. The experimental plot is superimposed on the figure, normalized at the boundary between the nonvoided and $40 \%$ void regions. The calculated $1 / e-$ folding length appears to be somewhat shorter; a value of 12.3 to 12.5 is approximated, being also about the same in both regions. In both experiment and calculation, the epithermal flux falls off at the same rate as the corresponding thermal flux.

Actually, it would have been better to have designated the interas sembly region of increased water with aluminum separately. The calculation seems to imply a somewhat less reactive situation than what was actually present. If the calculated thermal flux were spectrally corrected to correspond with the $\mathrm{U}^{235}$ activation cross section, magnitude shifts from voids to no voids would be expected to be in better agreement.

The radial thermal-flux dip acrosi an assembly was not shown by the problem. The experiment gave a value of 2.8 for the ratio of the flux at the assembly corner to that at the center, the measurement being along a diagonal. 


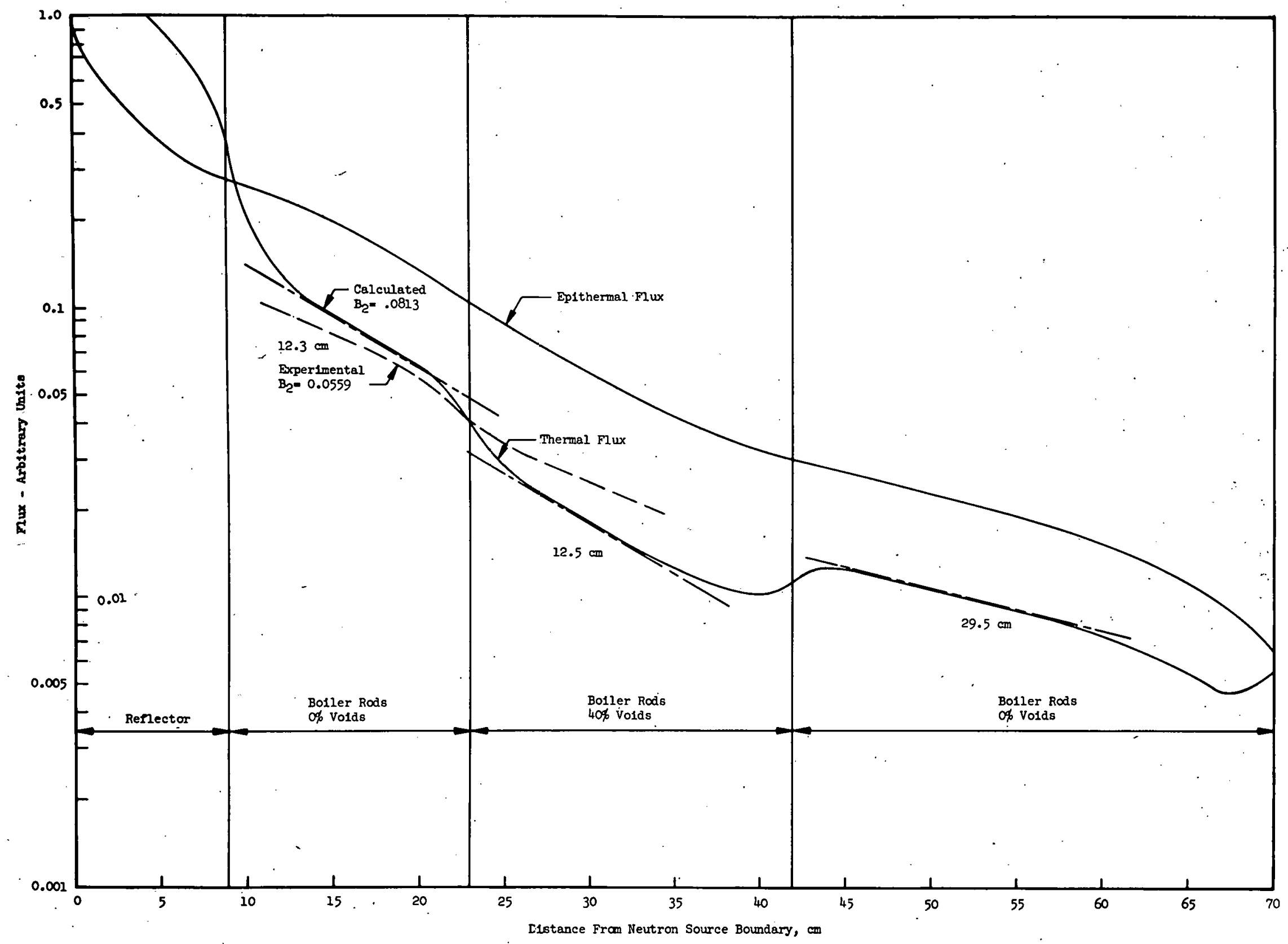




\section{APPENDIX A}

\section{A Summary of MUFT/SOFOCATE Cross Sections}

\section{for Uniformly Homogenized Cores}

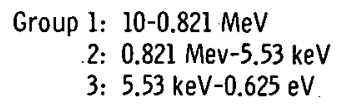

Group 1: $10-0.821 \mathrm{MeV}$

2: $0.821 \mathrm{Mev}-5.53 \mathrm{keV}$

3: $5.53 \mathrm{keV}-0.625 \mathrm{eV}$.

Fission in U238 occurs.

primarily in Group 1 and

resonance capture in Group 3
"Interpolated" constants were obtained by plotting the values from the first series in which U235 content was varied.

\begin{tabular}{|c|c|c|c|c|c|c|c|c|c|}
\hline \multicolumn{10}{|c|}{. Cross Sections } \\
\hline . & \multirow{2}{*}{\multicolumn{3}{|c|}{$\begin{array}{l}\text { Source of } \\
\text { Cross Sections }\end{array}$}} & \multirow[b]{2}{*}{ Type } & \multicolumn{3}{|c|}{ Three Fast Groups } & \multirow{2}{*}{$\begin{array}{l}\text { One } \\
\text { Fast } \\
\text { Group } \\
\text { I of } 1\end{array}$} & \multirow[b]{2}{*}{ Therma } \\
\hline Composition & & & & & 1 of 3 & 2 of 3 & 3 of 3 & & \\
\hline $\begin{array}{l}\text { Homogenized } \\
\text { boiler } \\
\text { with } 16.2 \mathrm{~g} \text { of U235 per rod }\end{array}$ & $\begin{array}{l}489^{\circ} \mathrm{F} \\
0 \% \text { voids }\end{array}$ & Interpolated & 60.67 . & $\begin{array}{l}D \\
\Sigma_{a} \\
\Sigma_{r} \\
v \Sigma_{f}\end{array}$ & & & . & $\begin{array}{l}1.4998 \\
0.008143 \\
0.01657 \\
0.00642\end{array}$ & $\begin{array}{l}0.4337 \\
0.1012 \\
- \\
0.1716\end{array}$ \\
\hline $\begin{array}{l}\text { Homogenized } \\
\text { boiler } \\
\text { with } 16.2 \mathrm{~g} \text { of U235 per rod }\end{array}$ & $\begin{array}{l}489^{\circ} \mathrm{F} \\
7 \frac{1}{2} \% \text { volds }\end{array}$ & Interpolated & & $\begin{array}{l}D \\
\sum_{a} \\
\sum_{r} \\
v \Sigma f\end{array}$ & & & & $\begin{array}{l}1.5420 \\
0.01691 \\
0.01522 \\
0.00644\end{array}$ & $\begin{array}{c}0.4589 \\
0.1003 \\
- \\
0.1708\end{array}$ \\
\hline $\begin{array}{l}\text { Homogenized } \\
\text { boiler } \\
\text { with } 16.2 \mathrm{~g} \text { of U235 per rod }\end{array}$ & $\begin{array}{l}489^{\circ} \mathrm{F} \\
15 \% \text { voids }\end{array}$ & $\begin{array}{c}M / S \\
11615056\end{array}$ & 70.46 & $\begin{array}{l}D \\
\Sigma_{a} \\
\Sigma_{r} \\
v \Sigma_{f}\end{array}$ & $\begin{array}{l}2.7284 \\
0.0035 \\
0.0603 \\
0.0062\end{array}$ & $\begin{array}{l}1.2708 \\
0.0021 \\
0.0530 \\
0.0011\end{array}$ & $\begin{array}{l}0.9698 \\
0.0198 \\
0.0439 \\
0.0135\end{array}$ & $\begin{array}{l}1.5870 \\
0.0081 \\
0.0139 \\
0.1694\end{array}$ & $\begin{array}{c}0.4848 \\
0.0992 \\
- \\
0.1694\end{array}$ \\
\hline $\begin{array}{l}\text { Homogenized } \\
\text { boiler } \\
\text { with } 16.2 \mathrm{~g} \text { of U235 per rod }\end{array}$ & $\begin{array}{l}70^{\circ} \mathrm{F} \\
0 \% \text { voids }\end{array}$ & $\begin{array}{c}M / S \\
21600062\end{array}$ & 44.25 & $\begin{array}{l}D \\
\Sigma_{\mathrm{a}} \\
\Sigma_{\mathrm{r}} \\
\nu \Sigma_{\mathrm{f}}\end{array}$ & $\begin{array}{l}2.3835 \\
0.0037 \\
0.0776 \\
0.0063\end{array}$ & $\begin{array}{l}1.0557 \\
0.0021 \\
0.0765 \\
0.0011\end{array}$ & $\begin{array}{l}0.7681 \\
0.0193 \\
0.0681 \\
0.0127\end{array}$ & $\begin{array}{l}1.3517 \\
0.0082 \\
0.0221 \\
0.0064\end{array}$ & $\begin{array}{l}0.3224 \\
0.1259 \\
- \\
0.2115\end{array}$ \\
\hline $\begin{array}{l}\text { Homogenized } \\
\text { boiler } \\
\text { with } 16.2 \mathrm{~g} \text { of } \mathrm{U}^{235} \text { per rod }\end{array}$ & $\begin{array}{c}70^{\circ} \mathrm{F} \\
\text { Contains } \mathrm{Bl} 10 \\
\left(\mathrm{~N}_{\mathrm{B}} 10=0.42 \times 10^{-5}\right)\end{array}$ & $\begin{array}{c}M / S \\
21600061\end{array}$ & 44.21 & $\begin{array}{l}D \\
\Sigma_{\mathrm{a}} \\
\Sigma_{\mathrm{r}} \\
v \Sigma_{\mathrm{f}}\end{array}$ & $\begin{array}{l}2.3834 \\
0.0037 \\
0.0776 \\
0.0063\end{array}$ & $\begin{array}{l}1.0556 \\
0.0021 \\
0.0765 \\
0.0011\end{array}$ & $\begin{array}{l}0.7670 \\
0.0199 \\
0.0676 \\
0.0127\end{array}$ & $\begin{array}{l}1.3518 \\
0.0084 \\
0.0219 \\
0.0064\end{array}$ & $\begin{array}{c}0.3245 \\
0.1338 \\
- \\
0.2081\end{array}$ \\
\hline $\begin{array}{l}\text { Homogenized } \\
\text { boiler } \\
\text { with } 32.4 \mathrm{~g} \text { of U235 per rod }\end{array}$ & $\begin{array}{l}70^{\circ} \mathrm{F} \\
0 \% \text { voids }\end{array}$ & $\begin{array}{c}M / S \\
23200104\end{array}$ & 44.08 & $\begin{array}{c}D \\
\Sigma_{a} \\
\Sigma_{r} \\
v \Sigma_{f}\end{array}$ & $\begin{array}{l}2.3828 \\
0.0039 \\
0.0774 \\
0.0068\end{array}$ & $\begin{array}{l}1.0541 \\
0.0026 \\
0.0763 \\
0.0021\end{array}$ & $\begin{array}{l}0.7613 \\
0.0255 \\
0.0653 \\
0.0241\end{array}$ & $\begin{array}{l}1.3578 \\
0.0102 \\
0.0205 \\
0.0104\end{array}$ & $\begin{array}{c}0.3328 \\
0.1869 \\
- \\
0.3492\end{array}$ \\
\hline $\begin{array}{l}\text { Homogenized } \\
\text { boiler } \\
\text {.. } \\
\end{array}$ & $\begin{array}{l}336^{\circ} \mathrm{F} \\
0 \% \text { voids }\end{array}$ & $\begin{array}{l}M / S \\
31600084\end{array}$ & 51.58 & $\begin{array}{c}D \\
\Sigma_{a} \\
\Sigma_{r} \\
v \Sigma_{f}\end{array}$ & $\begin{array}{l}2.4872 \\
0.0036 \\
0.0719 \\
0.0063\end{array}$ & $\begin{array}{l}1.1181 \\
0.0021 \\
0.0687 \\
0.0011\end{array}$ & $\begin{array}{l}0.8248 \\
0.0194 \\
0.0601 \\
0.0129\end{array}$ & $\begin{array}{l}1.4205 \\
0.0081 \\
0.0194 \\
0.0064\end{array}$ & $\begin{array}{c}0.3779 \\
0.1086 \\
- \\
0.1832\end{array}$ \\
\hline Water reflector & $\begin{array}{r}489^{\circ} \mathrm{F} \\
-\end{array}$ & $\begin{array}{c}\text { W/S } \\
59000129 \\
B^{2}=0.001\end{array}$ & 53.89 & $\begin{array}{l}D \\
\Sigma_{a} \\
\Sigma_{r} \\
v \Sigma_{r}\end{array}$ & $\begin{array}{l}4.2792 \\
0.001089 \\
0.08440 \\
0.0\end{array}$ & $\begin{array}{l}1.2308 \\
0.00001 \\
0.1196 \\
0.0\end{array}$ & $\begin{array}{l}0.7182 \\
0.00076 \\
0.1202 \\
0.0\end{array}$ & $\begin{array}{l}.2 .1268 \\
0.00063 \\
0.03883 \\
0.0\end{array}$ & $\begin{array}{c}0.2592 \\
0.0115 \\
- \\
0.0\end{array}$ \\
\hline Water reflector & $336^{\circ} \mathrm{F}$ & $\begin{array}{l}\text { WS } \\
30000090\end{array}$ & 38.27 & $\begin{array}{c}D \\
\Sigma_{a} \\
\Sigma r \\
v \Sigma_{f}\end{array}$ & $\begin{array}{l}3.3279 \\
0.0013 \\
0.0974 \\
0.0\end{array}$ & $\begin{array}{l}1.0980 \\
0.00001 \\
0.1339 \\
0.0\end{array}$ & $\begin{array}{l}0.6427 \\
0.0009 \\
0.1361 \\
0.0\end{array}$ & $\begin{array}{l}1.7153 \\
0.0007 \\
0.0441 \\
.0 .0\end{array}$ & $\begin{array}{c}0.2119 \\
0.0142 \\
- \\
0.0\end{array}$ \\
\hline Water reflector & $70^{\circ} \mathrm{F}$ & $\begin{array}{c}M / S \\
59000131 \\
B^{2}=0.001\end{array}$ & 34.05 & $\begin{array}{l}D \\
\Sigma_{a} \\
\Sigma_{r} \\
v \Sigma_{f}\end{array}$ & $\begin{array}{l}3.4082 \\
0.001393 \\
0.1059 \\
0.0\end{array}$ & $\begin{array}{l}0.9759 \\
0.000013 \\
0.1509 \\
0.0\end{array}$ & $\begin{array}{l}0.5695 \\
0.000952 \\
0.1517 \\
0.0\end{array}$ & $\begin{array}{l}1.6947 \\
0.000798 \\
0.04897 \\
0.0\end{array}$ & $\begin{array}{c}0.1594 \\
0.0193 \\
- \\
0.0\end{array}$ \\
\hline $\begin{array}{l}\mathrm{Al}-\mathrm{H}_{2} \mathrm{O} \\
\text { Volume fraction of } \mathrm{Al}=0.35\end{array}$ & & 22680133 & 48.96 & $\begin{array}{c}D \\
\Sigma_{a} \\
\sum_{r} \\
v \Sigma_{f}\end{array}$ & $\begin{array}{l}2.8991 \\
0.0010 \\
0.0761 \\
0.0\end{array}$ & $\begin{array}{l}1.1300 \\
0.00007 \\
0.0943 \\
0.0\end{array}$ & $\begin{array}{l}0.8506 \\
0.0010 \\
0.0948 \\
0.0\end{array}$ & $\begin{array}{l}1.6003 \\
0.0007 \\
0.0320 \\
0.0\end{array}$ & $\begin{array}{c}- \\
- \\
0.0\end{array}$ \\
\hline
\end{tabular}


Cross Sections

\begin{tabular}{|c|c|c|c|c|c|c|c|c|c|}
\hline & & & & & & Fast Gr & & $\begin{array}{l}\text { One } \\
\text { Fast } \\
\text { Group }\end{array}$ & \\
\hline Composition & Condition & Cross Sections & & Type & 1 of 3 & 2 of 3 & 3 of 3 & 1 of 1 & Thermal \\
\hline $\begin{array}{l}\text { Superheater } \\
\text { with } 680 \mathrm{~g} \text { of U235 per assembly }\end{array}$ & $\begin{array}{l}489^{\circ} \mathrm{F} \\
\text { Dry }\end{array}$ & $\begin{array}{c}\text { WS } \\
116800073\end{array}$ & 105.94 & $\begin{array}{c}D \\
\Sigma_{a} \\
\Sigma_{r} \\
v \Sigma_{f}\end{array}$ & $\begin{array}{l}3.4113 \\
0.0007 \\
0.0495 \\
0.0007\end{array}$ & $\begin{array}{l}1.5552 \\
0.0005 \\
0.0487 \\
0.0009\end{array}$ & $\begin{array}{l}0.9128 \\
0.0104 \\
0.0439 \\
0.0129\end{array}$ & $\begin{array}{l}1.8992 \\
0.0038 \\
0.0142 \\
0.0047\end{array}$ & $\begin{array}{c}0.4778 \\
0.0899 \\
- \\
0.1345\end{array}$ \\
\hline $\begin{array}{l}\text { Superheater } \\
\text { with } 680 \mathrm{~g} \text { of U235 per assembly }\end{array}$ & $\begin{array}{l}489^{\circ} \mathrm{F} \\
\text { Flooded }\end{array}$ & Interpolated & 55.36 & $\begin{array}{c}D \\
\Sigma_{a} \\
\Sigma_{r} \\
v \Sigma_{f}\end{array}$ & - & & & $\begin{array}{l}1.5305 \\
0.0041 \\
0.0236 \\
0.0049\end{array}$ & $\begin{array}{c}0.3549 \\
0.1006 \\
- \\
0.1484\end{array}$ \\
\hline $\begin{array}{l}\text { Super heater } \\
\text { with } 680 \mathrm{~g} \text { of U235 per assembly }\end{array}$ & $\begin{array}{l}336^{\circ} \mathrm{F} \\
\text { Dry }\end{array}$ & $\begin{array}{c}\text { W/S } \\
31680088\end{array}$ & 89.90 & $\begin{array}{c}0 \\
\Sigma_{a} \\
\Sigma_{r} \\
v \Sigma_{f}\end{array}$ & $\begin{array}{l}3.2572 \\
0.0008 \\
0.0540 \\
0.0007\end{array}$ & $\begin{array}{l}1.4616 \\
0.0005 \\
0.0548 \\
0.0009\end{array}$ & $\begin{array}{l}0.8582 \\
0.0106 \\
0.0499 \\
0.0130\end{array}$ & $\begin{array}{l}1.8032 \\
0.0039 \\
0.0162 \\
0.0048\end{array}$ & $\begin{array}{c}0.3214 \\
0.1202 \\
- \\
0.1303\end{array}$ \\
\hline $\begin{array}{l}\text { Superheater } \\
\text { with } 680 \mathrm{~g} \text { of U235 per assembly. }\end{array}$ & $\begin{array}{l}336^{\circ} \mathrm{F} \\
\text { Flooded }\end{array}$ & $\begin{array}{c}\text { W/S } \\
32680089\end{array}$ & 45.93 & $\begin{array}{c}D \\
\Sigma_{a} \\
\Sigma_{r} \\
v \Sigma_{f}\end{array}$ & $\begin{array}{l}2.6343 \\
0.0011 \\
0.0776 \\
0.0007\end{array}$ & $\begin{array}{l}1.2600 \\
0.0004 \\
0.1248 \\
0.0007\end{array}$ & $\begin{array}{l}0.6795 \\
0.0086 \\
0.0616 \\
0.0104\end{array}$ & $\begin{array}{l}1.4308 \\
0.0042 \\
0.0270 \\
0.0049\end{array}$ & $\begin{array}{c}0.3077 \\
0.1054 \\
- \\
0.1540\end{array}$ \\
\hline $\begin{array}{l}\text { Superheater } \\
\text { with } 680 \mathrm{~g} \text { of U235 per assembly. }\end{array}$ & $\begin{array}{l}70^{\circ} \mathrm{F} \\
\text { Dry }\end{array}$ & Interpolated & & $\begin{array}{c}D \\
\Sigma_{\mathrm{a}} \\
\Sigma_{\mathrm{r}} \\
\nu \Sigma_{\mathrm{f}}\end{array}$ & & & & $\begin{array}{l}1.7162 \\
0.0039 \\
0.0183 \\
0.0048\end{array}$ & $\begin{array}{c}0.3441 \\
0.1042 \\
- \\
0.1522\end{array}$ \\
\hline $\begin{array}{l}\text { Superheater } \\
\text { with } 680 \mathrm{~g} \text { of U235 per assembly }\end{array}$ & $\begin{array}{l}70^{\circ} \mathrm{F} \\
\text { Flooded }\end{array}$ & $\begin{array}{c}\text { WS } \\
22680076\end{array}$ & 38.97 & $\begin{array}{l}D \\
\Sigma_{a} \\
\Sigma r \\
v \Sigma_{f}\end{array}$ & $\begin{array}{l}2.4882 \\
0.0012 \\
0.0848 \\
0.0007\end{array}$ & $\begin{array}{l}1.0323 \\
0.0005 \\
0.0965 \\
0.0009\end{array}$ & $\begin{array}{l}0.6068 \\
0.0112 \\
0.0921 \\
0.0135\end{array}$ & $\begin{array}{l}1.3462 \\
0.0042 \\
0.0303 \\
0.0050\end{array}$ & $\begin{array}{l}0.2585 \\
0.1210 \\
- \\
0.1755\end{array}$ \\
\hline $\begin{array}{l}\text { Superheater } \\
\text { with } 430 \mathrm{~g} \text { of U235 per assembly }\end{array}$ & $\begin{array}{l}489^{\circ} \mathrm{F} \\
\text { Dry }\end{array}$ & $\begin{array}{c}\text { W/S } \\
11430067\end{array}$ & 106.93 & $\begin{array}{l}D \\
\Sigma_{a} \\
\sum_{r} \\
v \Sigma_{f}\end{array}$ & $\begin{array}{l}3.4127 \\
0.0006 \\
0.0495 \\
0.0004\end{array}$ & $\begin{array}{l}1.5569 \\
0.0003 \\
0.0488 \\
0.0006\end{array}$ & $\begin{array}{l}0.9108 \\
0.0076 \\
0.0452 \\
0.0084\end{array}$ & $\begin{array}{l}1.18904 \\
0.0028 \\
0.0149 \\
0.0032\end{array}$ & $\begin{array}{c}0.4791 \\
0.0715 \\
- \\
0.0922\end{array}$ \\
\hline $\begin{array}{l}\text { Superheater } \\
\text { with } 430 \mathrm{~g} \text { of U235 per assembly }\end{array}$ & $\begin{array}{l}489^{\circ} \mathrm{F} \\
\text { Flooded }\end{array}$ & Interpolated & 56.67 & $\begin{array}{l}D \\
\Sigma_{a} \\
\Sigma_{r} \\
v \Sigma_{f}\end{array}$ & & & · & $\begin{array}{l}1.5253 \\
0.0030 \\
0.0243 \\
0.0031\end{array}$ & $\begin{array}{c}0.3501 \\
0.0792 \\
- \\
0.1002\end{array}$ \\
\hline $\begin{array}{l}\text { Superheater } \\
\text { with } 430 \mathrm{~g} \text { of } \mathrm{U}^{235} \text { per assembly }\end{array}$ & $\begin{array}{l}336^{\circ} \mathrm{F} \\
\text { Dry }\end{array}$ & $\begin{array}{c}\text { M/S } \\
31430086\end{array}$ & 90.63 & $\begin{array}{l}D \\
\Sigma_{a} \\
\Sigma_{r} \\
v \Sigma_{f}\end{array}$ & $\begin{array}{l}3.2584 \\
0.0007 \\
0.0540 \\
0.0004\end{array}$ & $\begin{array}{l}1.4631 \\
0.0003 \\
0.0548 \\
0.0006\end{array}$ & $\begin{array}{l}0.8565 \\
0.0077 \\
0.0513 \\
0.0085\end{array}$ & $\begin{array}{l}1.7956 \\
0.0029 \\
0.0169 \\
0.0031\end{array}$ & $\begin{array}{l}0.4137 \\
0.0751 \\
- \\
0.0958\end{array}$ \\
\hline $\begin{array}{l}\text { Superheater } \\
\text { with } 430 \mathrm{~g} \text { of U235 per assembly }\end{array}$ & $\begin{array}{l}336^{\circ} \mathrm{F} \\
\text { Flooded }\end{array}$ & $\begin{array}{c}\text { M/S } \\
32430087\end{array}$ & 46.14 & $\begin{array}{c}D \\
\Sigma_{a} \\
\Sigma_{r} \\
v \Sigma_{f}\end{array}$ & $\begin{array}{l}2.6348 \\
0.0010 \\
0.0776 \\
0.0004\end{array}$ & $\begin{array}{l}1.1101 \\
0.0003 \\
0.0867 \\
0.0006\end{array}$ & $\begin{array}{l}0.6510 \\
0.0081 \\
0.0836 \\
0.0086\end{array}$ & $\begin{array}{l}1.4264 \\
0.0031 \\
0.0278 \\
0.0032\end{array}$ & $\begin{array}{c}0.3020 \\
0.0847 \\
- \\
0.1055\end{array}$ \\
\hline $\begin{array}{l}\text { Superheater } \\
\text { with } 430 \mathrm{~g} \text { of U235 per assembly }\end{array}$ & $\begin{array}{l}70^{\circ} \mathrm{F} \\
\text { Dry }\end{array}$ & Interpolated & 77.839 & $\begin{array}{c}D \\
\Sigma_{a} \\
\Sigma_{r} \\
v \Sigma_{f}\end{array}$ & $\begin{array}{l}3.1160 \\
0.0007 \\
0.0586 \\
0.0004\end{array}$ & $\begin{array}{l}1.3789 \\
0.0003 \\
0.0610 \\
0.0006\end{array}$ & $\begin{array}{l}0.8077 \\
0.0078 \\
0.0575 \\
0.0085\end{array}$ & $\begin{array}{l}1.7094 \\
0.0029 \\
0.0190 \\
0.0032\end{array}$ & $\begin{array}{c}0.3440 \\
0.0864 \\
- \\
0.1093\end{array}$ \\
\hline $\begin{array}{l}\text { Superheater } \\
\text { with } 430 \mathrm{~g} \text { of U235 per assembly }\end{array}$ & $\begin{array}{l}70^{\circ} \mathrm{F} \\
\text { Flooded }\end{array}$ & $\begin{array}{c}\text { W/S } \\
22430070\end{array}$ & $\begin{array}{l}39.132 \\
39.132\end{array}$ & $\begin{array}{c}D \\
\Sigma_{a} \\
\Sigma_{r} \\
v \Sigma_{f}\end{array}$ & $\begin{array}{l}2.4885 \\
0.0011 \\
0.0848 \\
0.0004\end{array}$ & $\begin{array}{l}1.0330 \\
0.0003 \\
0.0966 \\
0.0006\end{array}$ & $\begin{array}{l}0.6060 \\
0.0082 \\
0.0937 \\
0.0087\end{array}$ & $\begin{array}{l}1.3424 \\
0.0032 \\
0.0311 \\
0.0032\end{array}$ & $\begin{array}{c}0.2513 \\
0.0990 \\
- \\
0.1228\end{array}$ \\
\hline
\end{tabular}




\section{APPENDIX B}

Three-group Cross-section Set Used: in Flow-rod Studies

\section{Cross Sections}

\begin{tabular}{|c|c|c|c|c|c|}
\hline Composition & Condition & Type & Group 1 & Group 2 & Thermal \\
\hline $\begin{array}{l}\text { Boiler } \\
\text { Four flow rods } \\
45 \text { fuel rods }\end{array}$ & $\begin{array}{l}\text { Cold } \\
68^{\circ} \mathrm{F}\end{array}$ & $\begin{array}{l}\mathrm{D} \\
\Sigma_{\mathrm{a}} \\
\Sigma_{\mathrm{r}} \\
\nu \Sigma_{\mathrm{f}}\end{array}$ & $\begin{array}{l}1.7322 \\
0.0027 \\
0.0464 \\
0.0032\end{array}$ & $\begin{array}{l}0.7291 \\
0.0160 \\
0.0768 \\
0.0108\end{array}$ & $\begin{array}{c}0.3029 \\
0.1098 \\
- \\
0.1804\end{array}$ \\
\hline $\begin{array}{l}\text { Boiler } \\
\text { Four flow rods } \\
45 \text { fuel rods }\end{array}$ & $\begin{array}{l}489^{\circ} \mathrm{F} \\
\text { No steam voids }\end{array}$ & $\begin{array}{l}\mathrm{D} \\
\Sigma_{\mathrm{a}} \\
\sum_{\mathrm{r}} \\
\nu \Sigma_{\mathrm{f}}\end{array}$ & $\begin{array}{l}2.0441 \\
0.0026 \\
0.0373 \\
0.0032\end{array}$ & $\begin{array}{l}0.8967 \\
0.0158 \\
0.0595 \\
0.0110\end{array}$ & $\begin{array}{c}0.3731 \\
0.0916 \\
\cdots \\
0.1523\end{array}$ \\
\hline $\begin{array}{l}\text { Boiler } \\
\text { Eight flow rods } \\
41 \text { fuel rods }\end{array}$ & $\begin{array}{l}\text { Coldd } \\
68^{\circ} \mathrm{F}\end{array}$ & $\begin{array}{c}\mathrm{D} \\
\Sigma_{\mathrm{a}} \\
\sum_{\mathrm{r}} \\
\nu \Sigma_{\mathrm{f}}\end{array}$ & $\begin{array}{l}1.7603 \\
0.0027 \\
0.0474 \\
0.0030\end{array}$ & $\begin{array}{l}0.7282 \\
0.0149 \\
0.0800 \\
0.0098\end{array}$ & $\begin{array}{c}0.3023 \\
0.1067 \\
- \\
0.1741\end{array}$ \\
\hline $\begin{array}{l}\text { Boiler } \\
\text { Eight flow rods } \\
41 \text { fuel rods }\end{array}$ & $\begin{array}{c}489^{\circ} \mathrm{F} \\
\text { No steam voids }\end{array}$ & $\begin{array}{c}\mathrm{D} \\
\Sigma_{\mathrm{a}} \\
\sum_{\mathrm{r}} \\
\nu \Sigma_{\mathrm{f}}\end{array}$ & $\begin{array}{l}2.1978 \\
0.0023 \\
0.0378 \\
0.0029\end{array}$ & $\begin{array}{l}0.9332 \\
0.0147 \\
0.0619 \\
0.0100\end{array}$ & $\begin{array}{c}0.3723 \\
0.0887 \\
- \\
0.1467 \\
\end{array}$ \\
\hline $\begin{array}{l}\text { Boiler. } \\
12 \text { flow rods } \\
37 \text { fuel rods }\end{array}$ & $\begin{array}{l}\text { Cold } \\
68^{\circ} \mathrm{F}\end{array}$ & $\begin{array}{l}\mathrm{D} \\
\Sigma_{\mathrm{a}} \\
\sum_{\mathrm{r}} \\
\nu \Sigma_{\mathrm{f}}\end{array}$ & $\begin{array}{l}1.7889 \\
0.0023 \\
0.0485 \\
0.0027\end{array}$ & $\begin{array}{l}0.7214 \\
0.0138 \\
0.0832 \\
0.0089\end{array}$ & $\begin{array}{c}0.2851 \\
0.1002 \\
- \\
0.1631\end{array}$ \\
\hline $\begin{array}{l}\text { Boiler } \\
12 \text { flow rods } \\
37 \text { fuel rods }\end{array}$ & $\begin{array}{c}489^{\circ} \mathrm{F} \\
\text { No steam voids }\end{array}$ & $\begin{array}{l}\mathrm{D} \\
\sum_{\mathrm{a}} \\
\sum_{\mathrm{r}} \\
\nu \Sigma_{\mathrm{f}}\end{array}$ & $\begin{array}{l}1.9805 \\
0.0022 \\
0.0395 \\
0.0026\end{array}$ & $\begin{array}{l}0.8568 \\
0.0131 \\
0.0654 \\
0.0089\end{array}$ & $\begin{array}{c}0.3671 \\
0.0828 \\
- \\
0.1354\end{array}$ \\
\hline $\begin{array}{l}\text { Boiler } \\
12 \text { flow rods } \\
37 \text { fuel rods }\end{array}$ & $\begin{array}{c}48.9^{\circ} \mathrm{F} \\
10 \% \cdot \text { steam voids }\end{array}$ & $\begin{array}{c}\mathrm{D} \\
\Sigma_{\mathrm{a}} \\
\sum_{\mathrm{r}} \\
\nu \Sigma_{\mathrm{f}}\end{array}$ & $\begin{array}{l}2.0404 \\
0.0022 \\
0.0370 \\
0.0026\end{array}$ & $\begin{array}{l}0.9007 \\
0.0144 \\
0.0597 \\
0.0095\end{array}$ & $\begin{array}{c}0.4213 \\
0.0802 \\
- \\
0.1327\end{array}$ \\
\hline $\begin{array}{l}\text { Superheater } \\
430 \mathrm{~g} \text { of } \mathrm{U}^{235} \\
\text { per as sembly }\end{array}$ & $\begin{array}{l}\text { Cold } \\
\text { Flooded }\end{array}$ & $\begin{array}{l}\mathrm{D} \\
\Sigma_{\mathrm{a}} \\
\Sigma_{\mathrm{r}} \\
\nu \Sigma_{\mathrm{f}}\end{array}$ & $\begin{array}{l}1.7088 \\
0.0006 \\
0.0518 \\
0.0005\end{array}$ & $\begin{array}{l}0.6060 \\
0.0082 \\
0.0937 \\
0.0087\end{array}$ & $\begin{array}{c}0.2513 \\
0.0990 \\
- \\
0.1228\end{array}$ \\
\hline $\begin{array}{l}\text { Superheater } \\
430 \mathrm{~g} \text { of } \mathrm{U}^{235} \\
\text { per as sembly }\end{array}$ & $\begin{array}{l}\text { Cold } \\
\text { Dry }\end{array}$ & $\begin{array}{l}\mathrm{D} \\
\Sigma_{\mathrm{a}} \\
\Sigma_{\mathrm{r}} \\
\nu \Sigma_{\mathrm{f}}\end{array}$ & $\begin{array}{l}2.1556 \\
0.0005 \\
0.0337 \\
0.0005\end{array}$ & $\begin{array}{l}0.8077 \\
0.0077 \\
0.0575 \\
0.0084\end{array}$ & $\begin{array}{c}0.3440 \\
0.0864 \\
\ldots \\
0.1093\end{array}$ \\
\hline
\end{tabular}


Cross Sections

\begin{tabular}{|c|c|c|c|c|c|}
\hline Composition & Condition & Type & Group 1 & Group 2 & Thermal \\
\hline $\begin{array}{l}\text { Superheater } \\
430 \mathrm{~g} \text { of } \mathrm{U}^{235} \\
\text { per as sembly }\end{array}$ & $\begin{array}{c}489^{\circ} \mathrm{F} \\
\text { Flooded }\end{array}$ & $\begin{array}{l}\mathrm{D} \\
\sum_{\mathrm{a}} \\
\sum_{\mathrm{r}} \\
\nu \Sigma_{\mathrm{f}}\end{array}$ & $\begin{array}{l}1.9331 \\
0.0005 \\
0.0417 \\
0.0005\end{array}$ & $\begin{array}{l}0.7050 \\
0.0080 \\
0.0733 \\
0.0086\end{array}$ & $\begin{array}{c}0.3501 \\
0.0792 \\
- \\
0.1002\end{array}$ \\
\hline $\begin{array}{l}\text { Superheater } \\
430 \mathrm{~g} \text { of } \mathrm{U}^{235} \\
\text { per assembly }\end{array}$ & $\begin{array}{c}489^{\circ} \mathrm{F} \\
\text { Dry }\end{array}$ & $\begin{array}{l}\mathrm{D} \\
\sum_{\mathrm{a}} \\
\sum_{\mathrm{r}} \\
\nu \Sigma_{\mathrm{f}}\end{array}$ & $\begin{array}{l}2.3702 \\
0.0005 \\
0.0274 \\
0.0005\end{array}$ & $\begin{array}{l}0.9108 \\
0.0077 \\
0.0452 \\
0.0084\end{array}$ & $\begin{array}{c}0.4791 \\
0.0715 \\
- \\
0.0922\end{array}$ \\
\hline Reflector & $\begin{array}{l}\text { Cold } \\
68^{\circ} \mathrm{F}\end{array}$ & $\begin{array}{l}\mathrm{D} \\
\Sigma_{\mathrm{a}} \\
\sum_{\mathrm{r}} \\
\nu \Sigma_{\mathrm{f}}\end{array}$ & $\begin{array}{l}2.2311 \\
0.0735 \\
0.0730 \\
0.0\end{array}$ & $\begin{array}{l}0.5695 \\
0.1527 \\
0.1517 \\
0.0\end{array}$ & $\begin{array}{c}0.1594 \\
0.0193 \\
- \\
0.0\end{array}$ \\
\hline Reflector & $489^{\circ} \mathrm{F}$ & $\begin{array}{c}\mathrm{D} \\
\sum_{\mathrm{a}} \\
\sum_{\mathrm{r}}^{s} \\
\nu \Sigma_{\mathrm{f}}\end{array}$ & $\begin{array}{l}2.8011 \\
0.0586 \\
0.0581 \\
0.0\end{array}$ & $\begin{array}{l}0.7182 \\
0.1210 \\
0.1202 \\
0.0\end{array}$ & $\begin{array}{c}0.2592 \\
0.0115 \\
- \\
0.0\end{array}$ \\
\hline $\begin{array}{l}\text { Superheater } \\
680 \mathrm{~g} \text { of } \mathrm{U}^{235} \\
\text { per assembly }\end{array}$ & $\begin{array}{c}\text { Cold } \\
\text { Flooded }\end{array}$ & $\begin{array}{l}\mathrm{D} \\
\sum_{\mathrm{a}} \\
\sum_{\mathrm{r}} \\
\nu \Sigma_{\mathrm{f}}\end{array}$ & $\begin{array}{l}1.7085 \\
0.0008 \\
0.0517 \\
0.0008\end{array}$ & $\begin{array}{l}0.6068 \\
0.0113 \\
0.0921 \\
0.0135\end{array}$ & $\begin{array}{c}0.2585 \\
0.1210 \\
- \\
0.1755\end{array}$ \\
\hline $\begin{array}{l}\text { Superheater } \\
680 \mathrm{~g} \text { of } \overline{\mathrm{U}}^{235} \\
\text { per assembly }\end{array}$ & $\begin{array}{l}\text { Cold } \\
\text { Dry }\end{array}$ & $\begin{array}{c}D \\
\Sigma_{\mathrm{a}} \\
\Sigma_{r} \\
\nu \Sigma_{f}\end{array}$ & $\begin{array}{l}2.1552 \\
0.0007 \\
0.0366 \\
0.0008\end{array}$ & $\begin{array}{l}0.8091 \\
0.0106 \\
0.0565 \\
0.0133\end{array}$ & $\begin{array}{c}0.3441 \\
0.1042 \\
- \\
0.1522\end{array}$ \\
\hline $\begin{array}{l}\text { Superheater } \\
680 \mathrm{~g} \text { of } \mathrm{U}^{235} \\
\text { per assembly }\end{array}$ & $\begin{array}{c}489^{\circ} \mathrm{F} \\
\text { Flooded }\end{array}$ & $\begin{array}{l}\mathrm{D} \\
\sum_{\mathrm{a}} \\
\Sigma_{\mathrm{r}} \\
\nu \Sigma_{\mathrm{f}}\end{array}$ & $\begin{array}{l}1.9331 \\
0.0007 \\
0.0416 \\
0.0008\end{array}$ & $\begin{array}{l}0.7061 \\
0.010 .9 \\
0.0719 \\
0.0133\end{array}$ & $\begin{array}{c}0.4314 \\
0.1006 \\
- \\
0.1484\end{array}$ \\
\hline $\begin{array}{l}\text { Superheater } \\
680 \mathrm{~g} \text { of } \mathrm{U}^{235} \\
\text { per assembly }\end{array}$ & $\begin{array}{c}489^{\circ} \mathrm{F} \\
\operatorname{Dry}\end{array}$ & $\begin{array}{l}D \\
\Sigma_{\mathrm{a}} \\
\Sigma_{\mathrm{r}} \\
\nu \Sigma_{f}\end{array}$ & $\begin{array}{l}2.3691 \\
0.0006 \\
0.0274 \\
0.0008\end{array}$ & $\begin{array}{l}0.9128 \\
0.0104 \\
0.0439 \\
0.0129\end{array}$ & $\begin{array}{c}0.4778 \\
0.0899 \\
- \\
0.1345\end{array}$ \\
\hline
\end{tabular}




\section{APPENDIX C}

Atomic Densities Used in BORAX-V Core PSH-1

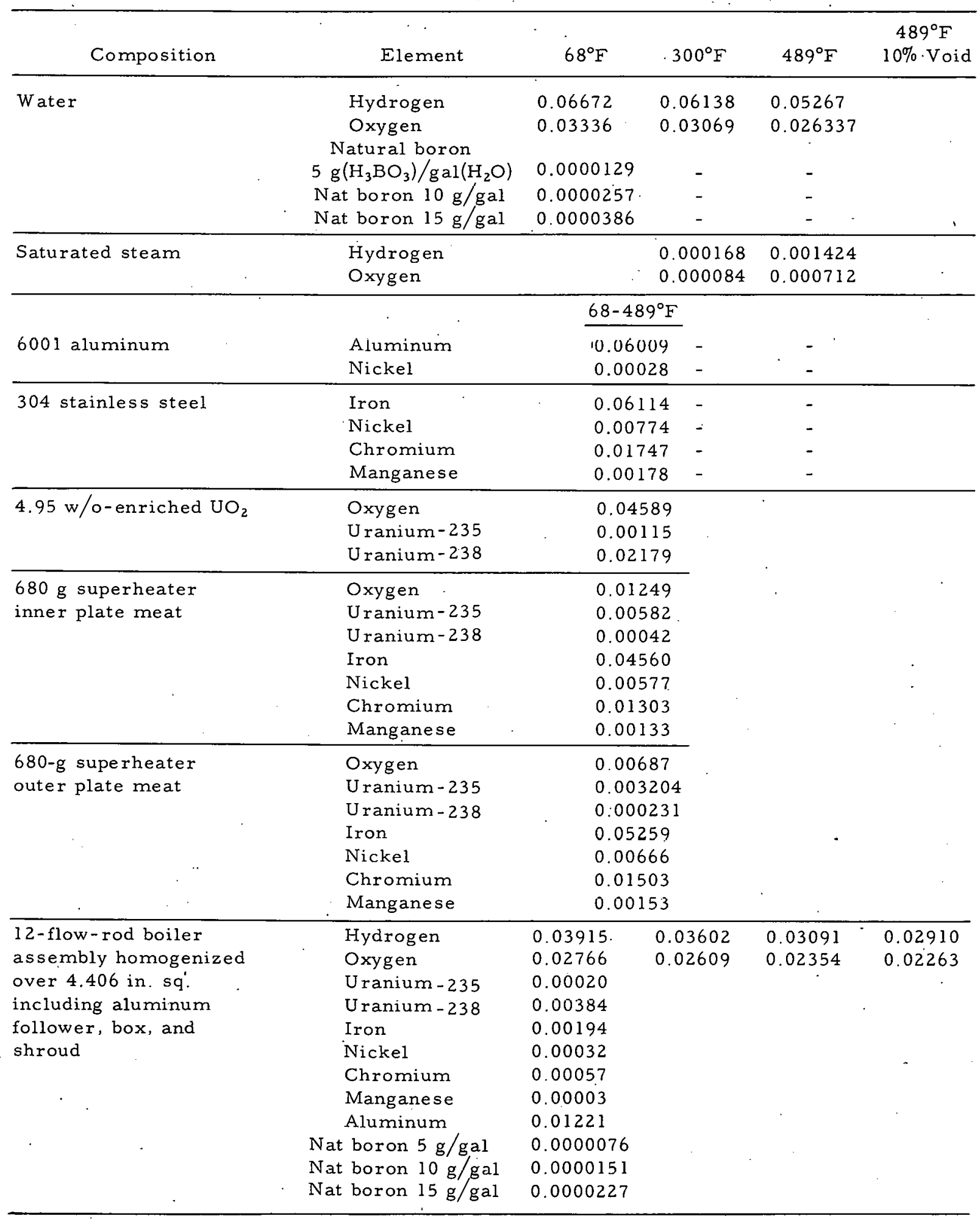




\begin{tabular}{|c|c|c|c|c|c|}
\hline Composition & Element & $68^{\circ} \mathrm{F}$ & $300^{\circ} \mathrm{F}$ & $489^{\circ} \mathrm{F}$ & $\begin{array}{c}489^{\circ} \mathrm{F} \\
10 \% \text { Void }\end{array}$ \\
\hline $\begin{array}{l}\text { 12-flow-rod boiler } \\
\text { fuel homogenized } \\
\text { over } 3.375 \text { in. sq. }\end{array}$ & $\begin{array}{l}\text { Hydrogen } \\
\text { Oxygen } \\
\text { Uranium-235 } \\
\text { Uranium-238 } \\
\text { Iron } \\
\text { Nickel } \\
\text { Chromium } \\
\text { Manganese } \\
\text { Aluminum } \\
\text { Nat boron } 5 \mathrm{~g} / \mathrm{gal} \\
\text { Nat boron } 10 \mathrm{~g} / \mathrm{gal} \\
\text { Nat boron } 15 . \mathrm{g} / \mathrm{gal}\end{array}$ & $\begin{array}{l}0.04157 \\
0.03456 \\
0.00035 \\
0.00654 \\
0.00326 \\
0.00042 \\
0.00093 \\
0.00010 \\
0.00141 \\
0.0000080 \\
0.0000160 \\
0.0000240\end{array}$ & $\begin{array}{l}0.03824 \\
0.03289\end{array}$ & $\begin{array}{l}0.03282 \\
0.03018\end{array}$ & $\begin{array}{l}0.02954 \\
0.02854\end{array}$ \\
\hline $\begin{array}{l}\text { 49-fuel-rod boiler } \\
\text { assembly homogenized } \\
\text { over } 4.406 \text { in. sq. } \\
\text { including aluminum } \\
\text { follower, box, and } \\
\text { shroud }\end{array}$ & $\begin{array}{l}\text { Hydrogen } \\
\text { Oxygen } \\
\text { Uranium-235 } \\
\text { Uranium-238 } \\
\text { Iron } \\
\text { Nickel } \\
\text { Chromium } \\
\text { Manganese } \\
\text { Aluminum }\end{array}$ & $\begin{array}{l}0.03580 \\
0.02860 \\
0.00027 \\
0.00508 \\
0.00253 \\
0.00037 \\
0.00072 \\
0.00007 \\
0.01134\end{array}$ & $\begin{array}{l}0.03293 \\
0.02717\end{array}$ & $\begin{array}{l}0.08282 \\
0.02483\end{array}$ & \\
\hline $\begin{array}{l}\text { 49-fuel-rod boiler } \\
\text { fuel region homogenized } \\
\text { over } 3.375 \text { in. sq. }\end{array}$ & $\begin{array}{l}\text { Hydrogen } \\
\text { Oxygen } \\
\text { Uranium }-235 \\
\text { Uranium }-238 \\
\text { Iron } \\
\text { Nickel } \\
\text { Chromium } \\
\text { Manganese }\end{array}$ & $\begin{array}{l}0.03549 \\
0.03598 \\
0.00046 \\
0.00866 \\
0.00432 \\
0.00055 \\
0.00123 \\
0.00013\end{array}$ & $\begin{array}{l}0.03264 \\
0.03456\end{array}$ & $\begin{array}{l}0.02802 \\
0.03225\end{array}$ & \\
\hline $\begin{array}{l}\text { Boiler assembly box } \\
\text { and wafer between } \\
\text { boxes, homogenized }\end{array}$ & $\begin{array}{l}\text { Hydrogen } \\
\text { Oxygen } \\
\text { Aluminum } \\
\text { Nickel } \\
\text { Nat boron } 5 \mathrm{~g} / \mathrm{gal} \\
\text { Nat boron } 10 \mathrm{~g} / \mathrm{gal} \\
\text { Nat boron } 15 \mathrm{~g} / \mathrm{gal}\end{array}$ & $\begin{array}{l}0.03336 \\
0.01668 \\
0.03004 \\
0.00014 \\
0.0000064 \\
0.0000129 \\
0.0000193\end{array}$ & $\begin{array}{l}0.03069 \\
0.01534\end{array}$ & $\begin{array}{l}0.02634 \\
0.01317\end{array}$ & . \\
\hline $\begin{array}{l}\text { Boiler assembly box, } \\
\text { shroud, water between } \\
\text { box and shroud, and } \\
\text { water between shroud } \\
\text { and follower, homogenized }\end{array}$ & $\begin{array}{l}\text { Hydrogen } \\
\text { Oxygen } \\
\text { Aluminum } \\
\text { Nickel } \\
\mathrm{Nat} \text { boron } 5 \mathrm{~g} / \mathrm{gal} \\
\mathrm{Nat} \text { boron } 10 \mathrm{~g} / \mathrm{gal} \\
\mathrm{Nat} \text { boron } 15 \mathrm{~g} / \mathrm{gal}\end{array}$ & $\begin{array}{l}0.02783 \\
0.01391 \\
0.03505 \\
0.000163 \\
0.0000054 \\
0.0000107 \\
0.0000161\end{array}$ & $\begin{array}{l}0.02557 \\
0.01279\end{array}$ & $\begin{array}{l}0.02407 \\
0.01203\end{array}$ & . \\
\hline $\begin{array}{l}\text { Superheater assembly } \\
\text { box and insulator gap } \\
\text { homogenized }\end{array}$ & $\begin{array}{l}\text { Iron } \\
\text { Nickel } \\
\text { Chromium } \\
\text { Manganese }\end{array}$ & $\begin{array}{l}0.03057 \\
0.00387 \\
0.00874 \\
0.00089\end{array}$ & - & & . \\
\hline
\end{tabular}




\begin{tabular}{|c|c|c|c|c|c|c|}
\hline Composition & Element & $68^{\circ} \mathrm{F}$ & $300^{\circ} \mathrm{F}$ & $489^{\circ} \mathrm{F}$ & $\begin{array}{l}489 \\
10 \%\end{array}$ & $\begin{array}{l}9^{\circ} \mathrm{F} \\
\text { Void }\end{array}$ \\
\hline $\begin{array}{l}680-g \text { superheater } \\
\text { homogenized over } \\
4.406 \text { in. sq. including } \\
\text { aluminum follower and } \\
\text { shroud }\end{array}$ & 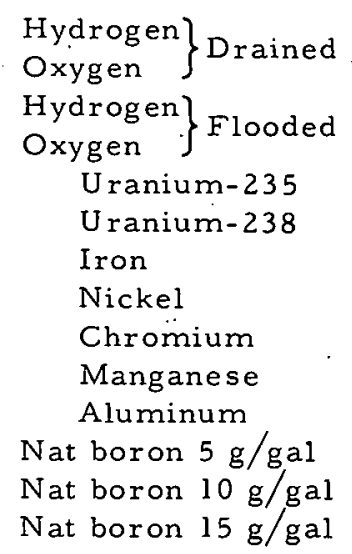 & $\begin{array}{l}0.02879 \\
0.01488 \\
0.04011 \\
0.02054 \\
0.000228 \\
0.000016 \\
0.01059 \\
0.00148 \\
0.00309 \\
0.00015 \\
0.00842 \\
0.0000055 \\
0.0000111 \\
0.0000166\end{array}$ & $\begin{array}{l}0.02652 \\
0.01375 \\
0.03689 \\
0.01894\end{array}$ & $\begin{array}{l}0.02306 \\
0.01202 \\
0.03166 \\
0.01632\end{array}$ & $\cdot$ & . \\
\hline $\begin{array}{l}680-g \text { superheater fuel } \\
\text { region, bounded by end } \\
\text { of fuel meat and outer } \\
\text { plate cladding, including } \\
\text { spacers }\end{array}$ & $\begin{array}{l}\left.\begin{array}{l}\text { Hydrogen } \\
\text { Oxygen }\end{array}\right\} \text { Drained } \\
\left.\begin{array}{l}\text { Hydrogen } \\
\text { Oxygen }\end{array}\right\} \text { Flooded } \\
\text { Uranium-235 } \\
\text { Uranium-238 } \\
\text { Iron } \\
\text { Nickel } \\
\text { Chromium } \\
\text { Manganese }\end{array}$ & $\begin{array}{l}0.0 \\
0.00177 \\
0.03911 \\
0.02133 \\
0.000826 \\
0.000059 \\
0.02414 \\
0.00306 \\
0.00690 \\
0.00070\end{array}$ & $\begin{array}{l}0.00010 \\
0.00182 \\
0.03598 \\
0.01976\end{array}$ & $\begin{array}{l}0.00084 \\
0.00219 \\
0.03087 \\
0.01721\end{array}$ & & \\
\hline $\begin{array}{l}\text { Superheater element box, } \\
\text { end, water between box } \\
\text { ends, homogenized }\end{array}$ & 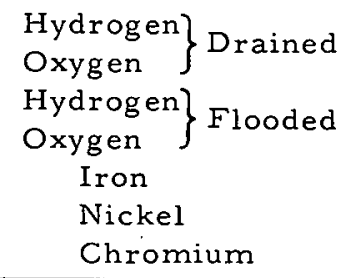 & $\begin{array}{l}0.01678 \\
0.00839 \\
0.02650 \\
0.01325 \\
0.03399 \\
0.00430 \\
0.00971\end{array}$ & $\begin{array}{l}0.01544 \\
0.00772 \\
0.02437 \\
0.01218\end{array}$ & $\begin{array}{l}0.01345 \\
0.00673 \\
0.02091 \\
0.01045\end{array}$ & & \\
\hline $\begin{array}{l}\text { Superheater element box, } \\
\text { end; water between box } \\
\text { ends, homogenized }\end{array}$ & $\begin{array}{l}\text { Manganese } \\
\text { Nat boron } 5 \mathrm{~g} / \mathrm{gal} \\
\text { Nat boron } 10 \mathrm{~g} / \mathrm{gal} \\
\text { Nat boron } 15 \mathrm{~g} / \mathrm{gal}\end{array}$ & $\begin{array}{l}0.00099 \\
0.0000032 \\
0.0000065 \\
0.0000097\end{array}$ & & & - & \\
\hline $\begin{array}{l}\text { Control-rod cladding } \\
\text { material, homogenized }\end{array}$ & $\begin{array}{l}\text { Iron } \\
\text { Nickel } \\
\text { Chromium } \\
\text { Manganese } \\
\text { Aluminum }\end{array}$ & $\begin{array}{l}0.04541 \\
0.00617 \\
0.01324 \\
0.00066 \\
0.01461\end{array}$ & & & - & . \\
\hline $\begin{array}{l}\text { Control-rod poison } \\
\text { boral }\end{array}$ & $\begin{array}{l}\text { Aluminum } \\
\text { Carbon } \\
\text { Nat boron }\end{array}$ & $\begin{array}{l}0.02898 \\
0.01544 \\
0.06176\end{array}$ & & & & \\
\hline $\begin{array}{l}\text { Poison rod poison, } \\
B_{4} C \text {, stainless steel }\end{array}$ & $\begin{array}{l}\text { Iron } \\
\text { Nickel } \\
\text { Chromium } \\
\text { Manganese } \\
\text { Carbon } \\
\text { Nat boron }\end{array}$ & $\begin{array}{l}0.05734 \\
0.00726 \\
0.01639 \\
0.00167 \\
0.002024 \\
0.008095\end{array}$ & & . & & . \\
\hline
\end{tabular}




\section{APPENDIX D}

Thermal Constants for Fuel-assembly Cell Calculations

1. Thermal Constants for $4.95 \mathrm{w} / \mathrm{o}$-enriched $\mathrm{UO}_{2}$ Boiler Pin Cell Calculations

\begin{tabular}{|c|c|c|c|c|c|}
\hline $\begin{array}{l}\text { Temp, } \\
\stackrel{\circ}{\circ} \mathrm{F}\end{array}$ & $\begin{array}{c}\text { Boric Acid } \\
\text { Conćentration, } \\
\mathrm{g}\left(\mathrm{H}_{3} \mathrm{BO}_{3}\right) / \\
\mathrm{gal}\left(\mathrm{H}_{2} \mathrm{O}\right)\end{array}$ & Material & $\Sigma_{a}$ & $\Sigma_{\text {so }}$ & $\Sigma_{S_{1}}$ \\
\hline \multirow[t]{3}{*}{68} & 0 & $\mathrm{UO}_{2}$ & 0.6026 & 0.3805 & 0.0085 \\
\hline & 0 & 304 stainless steel & 0.1919 & 0.8562 & 0.0101 \\
\hline & 0 & $\mathrm{H}_{2} \mathrm{O}$ & 0.0164 & 2.705 & 0.613 \\
\hline \multirow[t]{3}{*}{68} & 5 & $\mathrm{UO}_{2}$ & 0.3996 & 0.3805 & 0.0085 \\
\hline & 5 & 304 stainless steel & 0.1910 & 0.8562 & 0.0101 \\
\hline & 5 & $\mathrm{H}_{2} \mathrm{O}$ plus $\mathrm{H}_{3} \mathrm{BO}_{3}$ & 0.0235 & 2.697 & 0.614 \\
\hline \multirow[t]{3}{*}{68} & 10 & $\mathrm{UO}_{2}$ & 0.5966 & 0.3805 & 0.0085 \\
\hline & 10 & 304 stainless steel & 0.1901 & 0.8562 & 0.0101 \\
\hline & 10 & $\mathrm{H}_{2} \mathrm{O}+\mathrm{H}_{3} \mathrm{BO}_{3}$ & 0.0306 & $2.690^{\circ}$ & 0.616 \\
\hline \multirow[t]{3}{*}{68} & 15 & $u \cap_{2}$ & 0.5937 & 0.3805 & 0.0085 \\
\hline & 15 & 304 stainless steel & 0.1892 & 0.8562 & 0.0101 \\
\hline & 15 & $\mathrm{H}_{2} \mathrm{O}+\mathrm{H}_{3} \mathrm{BO}_{3}$ & 0.0376 & 2.683 & 0.618 \\
\hline \multirow[t]{3}{*}{300} & 0 & $\mathrm{UO}_{2}$ & 0.5190 & 0.3805 & 0.0085 \\
\hline & 0 & 304 stainless steel & 0.1683 & 0.8562 & 0.0101 \\
\hline & 0 & $\mathrm{H}_{2} \mathrm{O}$ & 0.0132 & 2.311 & 0.608 \\
\hline \multirow[t]{3}{*}{489} & 0 & $\mathrm{UO}_{2}$ & 0.4690 & 0.3805 & 0.0085 \\
\hline & 0 & 304 stainless steel & 0.1536 & 0.8562 & 0.0101 \\
\hline & 0 & $\mathrm{H}_{2} \mathrm{O}$ & $0: 010.3$ & 1.887 & 0.546 \\
\hline \multirow{3}{*}{$\begin{array}{c}489 \\
10 \% \text { void }\end{array}$} & 0 & $\mathrm{UO}_{2}$ & 0.4665 & 0.3805 & 0.0085 \\
\hline & 0 & 304 stainiess steel & 0.1528 & 0.8562 & 0.0101 \\
\hline & 0 & $. \cdot \mathrm{H}_{2} \mathrm{O}, 10 \%$ voids & 0.0093 & 1.6938 & 0.492 \\
\hline
\end{tabular}


2. Thermal Constants for 680-g Superheater Plate Cell Calculations

\begin{tabular}{|c|c|c|c|c|c|c|}
\hline $\begin{array}{l}\text { Superheater } \\
\text { Condition }\end{array}$ & $\underset{ }{\mathrm{T}} \underset{\mathrm{o}}{\mathrm{O}} \mathrm{F}$ & $\dot{C}_{B}$ & Material & $\Sigma_{\mathrm{a}}$ & $\Sigma_{\text {so }_{0}}$ & $\Sigma_{s_{1}}$ \\
\hline \multirow[t]{4}{*}{ Flooded } & $68^{\circ}$ & 0 & $\mathrm{H}_{2} \mathrm{O}$ & 0.01585 & 2.657 & 0.625 \\
\hline & & 0 & 304 SS & 0.1861 & 0.8562 & 0.0101 \\
\hline & & 0 & Outer-plate meat & $1: 666$ & 0.7993 & 0.0100 \\
\hline & & 0. & Inner-plate meat & 2.878 & 0.7528 & 0.0100 \\
\hline \multirow{4}{*}{ Drained } & 68 & 0 & $\mathrm{H}_{2} \mathrm{O}$ & 0.01504 & 2.577 & 0.644 \\
\hline & & 0. & 304 SS & 0.1765 & 0.8562 & 0.0101 \\
\hline & & 0 & Outer-plate meat & 1.575 & 0.7993 & 0.0100 \\
\hline & & 0 & Inner-plate meat & 2.719 & 0.7528 & 0.0100 \\
\hline \multirow{4}{*}{ Drained } & 68 & 2 & $\mathrm{H}_{2} \mathrm{O}+\mathrm{H}_{3} \mathrm{BO}_{3}$ & .0 .01767 & 2.575 & 0.645 \\
\hline & & 2 & 304 SS & 0.1762 & 0.8562 & 0.0101 \\
\hline & & 2 & Outer-plate meat & 1.572 & 0.7993 & 0.0100 \\
\hline & & 2 & Inner-plate meat & 2.714 & 0.7528 & 0.0100 \\
\hline \multirow[t]{4}{*}{ Drained } & 68 & 5 & $\mathrm{H}_{2} \mathrm{O}+\mathrm{H}_{3} \mathrm{BO}_{3}$ & 0.02162 & 2.572 & 0.646 \\
\hline & & 5 & 304 SS & 0.1758 & 0.8562 & 0.0101 \\
\hline & & 5 & Outer-plate meat & 1.569 & 0.7993 & 0.0100 \\
\hline & & 5 & Inner-plate meat & 2.708 & 0.7528 & 0.0100 \\
\hline \multirow[t]{4}{*}{ Drained } & 68 & 10 & $\mathrm{H}_{2} \mathrm{O}+\mathrm{H}_{3} \mathrm{BO}_{3}$ & 0.02815 & 2.567 & 0.647 \\
\hline & & 10 & 304 SS & 0.1752 & 0.8562 & 0.0101 \\
\hline & & 10 & Outer-plate meat & 1.563 & 0.7993 & 0.0100 \\
\hline & & 10 & Inner-plate meat & 2.7 .03 & 0.7528 & 0.0100 \\
\hline \multirow[t]{4}{*}{ Drained } & 68 & 15 & $\mathrm{H}_{2} \mathrm{O}+\mathrm{H}_{3} \mathrm{BO}_{3}$ & 0.03465 & 2.562 & 0.649 \\
\hline & & 15 & 304 SS & 0.1746 & 0.8562 & 0.0101 \\
\hline & & 15 & Outer-plate meat & 1.557 & 0.7993 & 0.0100 \\
\hline & & 15 & Inner-plate meat & 2.693 & 0.7528 & 0.0100 \\
\hline \multirow[t]{5}{*}{ Flooded } & 300 & 0 & $\mathrm{H}_{2} \mathrm{O}$ & 0.01289 & 2.281 & 0.615 \\
\hline & . & 0 & 304 SS & 0.1644 & 0.8562 & 0.0101 \\
\hline & & 0 & Outer-plate meat & 1.448 & 0.7993 & 0.0100 \\
\hline & & 0 & Inner-plate meat & 2.498 & 0.7528 & 0.0100 \\
\hline & & Satu. & rated Steam: & $3.075 \times 10^{-5}$ & $5.546 \times 10^{-3}$ & $1.561 \times 10^{-3}$ \\
\hline \multirow[t]{4}{*}{ Drained } & 300 & 0 & $\mathrm{H}_{2} \mathrm{O}$ & 0.01237 & 2.231 & 0.628 \\
\hline & & 0 & $304 \mathrm{SS}$ & 0,1579 & 0.8562 & 0.0101 \\
\hline & & 0 & Outer-plate meat & 1.388 & 0.7993 & 0.0100 \\
\hline & & 0 & Inner-plate meat & 2.394 & 0.7528 & 0.0100 \\
\hline
\end{tabular}




\begin{tabular}{|c|c|c|c|c|c|c|}
\hline $\begin{array}{l}\text { Superheater } \\
\text { Condition }\end{array}$ & $\begin{array}{l}\text { Temp, } \\
{ }^{\circ} \mathrm{F}\end{array}$ & $\mathrm{C}_{\mathrm{B}}$ & Material & $\Sigma_{\mathrm{a}}$ & $\Sigma_{\text {so }}$ & $\Sigma_{\text {s1 }}$ \\
\hline \multirow[t]{5}{*}{ Flooded } & \multirow[t]{4}{*}{489} & 0 & $\mathrm{H}_{2} \mathrm{O}$ & 0.01012 & 1.867 & 0.552 \\
\hline & & 0 & 304 S.S & 0.1579 & 0.8562 & 0.0101 \\
\hline & & 0 & Outer-plate meat & 1.388 & 0.7993 & 0.0100 \\
\hline & & 0 & Inner-plate meat & 2.265 & 0.7528 & 0.0100 \\
\hline & & Satu & rated Șteam: & $1.955 \times 10^{-4}:$ & $3.664 \times 10^{-2}$ & $1.119 \times 10^{-2}$ \\
\hline \multirow[t]{5}{*}{ Drained } & 489 & 0 & $\mathrm{H}_{2} \mathrm{O}$ & 0.009787 & 1.834 & 0.560 \\
\hline & \multirow{4}{*}{${ }^{\circ}$} & 0 & Saturated steam & 0.0002646 & 0.04958 & 0.01514 \\
\hline & & 0 & 304 SS & 0.1455 & 0.8562 & 0.0101 \\
\hline & & 0 & Outer-plate meat & 1.269 & 0.7993 & 0.0100 \\
\hline & & 0 & Inner-plate meat & 2.188 & 0.7528 & 0.0100 \\
\hline
\end{tabular}


APPENDIX E

Four-group Constants for PDQ Calculations

12 - FLOW - ROD BOILER

680 - g SUPERHEATER PSH CORE

1. $68^{\circ} \mathrm{F}$, No Boric Acid

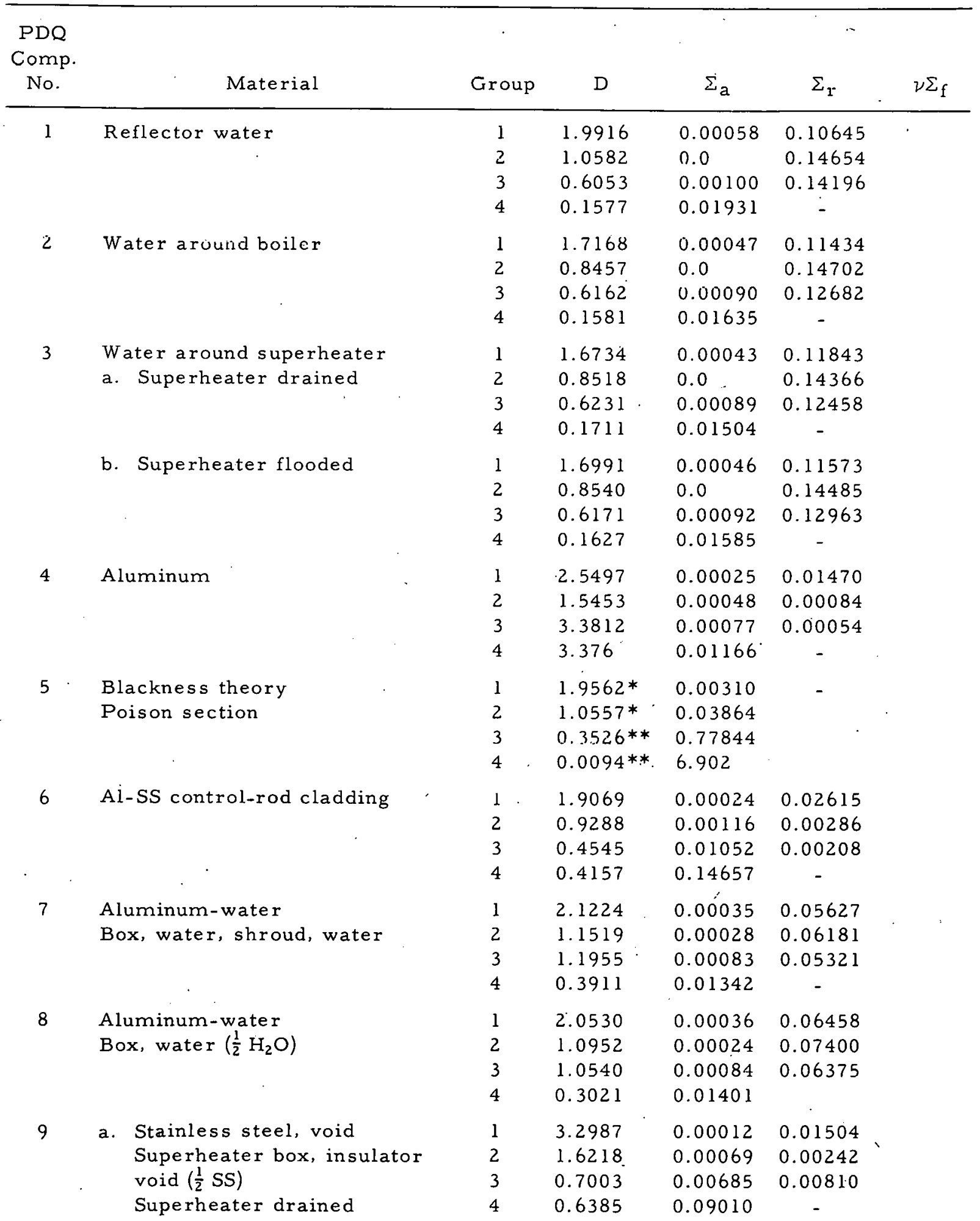


1. $68^{\circ} \mathrm{F}$, No Boric Acid (Contd.)

\begin{tabular}{|c|c|c|c|c|c|c|}
\hline $\begin{array}{l}\text { PDQ } \\
\text { Comp. } \\
\text { No. }\end{array}$ & Material & Group & $\mathrm{D}$ & $\Sigma_{\mathrm{a}}$ & $\Sigma_{\mathbf{r}}$ & $\nu \Sigma_{\mathrm{f}}$ \\
\hline \multirow[t]{4}{*}{9} & b. Stainless steel, void & 1 & 3.3080 & 0.00012 & $0.0 .1493^{\circ}$ & \\
\hline & Superheater box, & 2 & 1.6168 & 0.00069 & 0.00175 & \\
\hline & insulator void & 3 & 0.7008 & 0.00701 & 0.00132 & \\
\hline & Superheater flooded & 4 & 0.6384 & 0.09414 & - & \\
\hline \multirow[t]{8}{*}{10} & \multirow{4}{*}{$\begin{array}{l}\text { Stainless steel, water } \\
\text { a. Superheater box end, water } \\
\text { Superheater drained }\end{array}$} & 1 & 2.1034 & 0.00024 & 0.04637 & \\
\hline & & 2 & 1.0277 & 0.00076 & 0.03806 & \\
\hline & & 3 & 0.5032 & 0.00783 & 0.03273 & \\
\hline & & 4 & 0.3140 & 0.10216 & - & \\
\hline & \multirow{4}{*}{$\begin{array}{l}\text { b. Superheater box end, } \\
\text { water } \\
\text { Superheater flooded }\end{array}$} & 1 & 1.8038 & 0.00031 & 0.06255 & \\
\hline & & 2 & 0.8755 & 0.00077 & 0.05947 & \\
\hline & & 3 & 0.4495 & 0.00816 & 0.05294 & \\
\hline & & 4 & 0.2403 & 0.10975 & - & \\
\hline \multirow[t]{8}{*}{11} & \multirow{4}{*}{$\begin{array}{l}\text { Boiler fuel } \\
\text { Homogenized over } 3.375 \text { in. sq. } \\
\text { a. GAM No. } 139 \text { for } \mathrm{U}^{238}\end{array}$} & 1 & 1.8338 & 0.00394 & 0.08830 & 0.00815 \\
\hline & & 2 & 0.9745 & 0.00291 & 0.09184 & 0.00162 \\
\hline & & 3 & 0.5643 & 0.03079 & 0.07511 & 0.02454 \\
\hline & & 4 & 0.1895 & 0.17249 & - & 0.28999 \\
\hline & \multirow[t]{4}{*}{ b. GAM No. 12. for $U^{238}$} & 1 & 1.6822 & 0.00386 & 0.08847 & 0.00840 \\
\hline & & 2 & 0.8632 & 0.00178 & 0.09257 & 0.00161 \\
\hline & & 3 & 0.5276 & 0.03097 & $0: 07971$ & 0.02511 \\
\hline & & 4 & 0.1895 & 0.17249 & - & 0.28999 \\
\hline \multirow[t]{8}{*}{12} & \multirow{4}{*}{$\begin{array}{l}\text { a. Superheater fuel } \\
\text { Superheater flooded }\end{array}$} & 1 & 1.7040 & 0.00147 & 0.08069 & 0.00305 \\
\hline & & 2 & 0.8388 & 0.00231 & 0.08633 & 0.00385 \\
\hline & & 3 & 0.4556 & 0.04560 & 0.77057 & 0.06079 \\
\hline & & 4 & 0.1678 & 0.45566 & - & 0.77 .635 \\
\hline & \multirow{4}{*}{$\begin{array}{l}\text { b. Superheater fuel } \\
\text { Superheater drained }\end{array}$} & 1 & 3.8008 & 0.00120 & 0.01287 & $0: 00304$ \\
\hline & & 2 & 1.9301 & 0.00231 & 0.00140 & 0.00384 \\
\hline & & 3 & 0.7999 & 0.04443 & 0.00102 & 0.05993 \\
\hline & & 4 & 0.4302 & 0.43407 & - & 0.75449 \\
\hline
\end{tabular}

*From homogenized boiler.

**From blackness calculation.

13 Boron -SS poison rod--method of obtaining constants

$\left.\begin{array}{l}1.83 \mathrm{w} / \mathrm{o} \mathrm{B}^{\text {nat }} \\ \text { in } 304 \mathrm{SS}\end{array}\right\}$ radius $=0.32893 \mathrm{~cm}$

$\mathrm{SS}$ clad, outer radius $=0.47625 \mathrm{~cm}$

Pin-cell area in 12 -flow-rod boiler homogenized over 3.375 in. sq. = $1.9861555 \mathrm{~cm}^{2}$.

Poison-section area $=0.33990 \mathrm{~cm}^{2}, \quad$ Volume fraction $=0.171137 ;$

Stainless-steel-clad

section $\quad=0.37265 \mathrm{~cm}^{2}, \quad$ Volume fraction $=0.187625$;

Water area $\quad=1.273598 \mathrm{~cm}^{2}, \quad$ Volume fraction $=0.641238$. 
The poison section has

SS volume fraction $=0.937905 ;$

$\mathrm{B}^{\text {nat }}$ volume fraction $=0.0620 .95$

$\mathrm{N}\left(\mathrm{B}^{\text {nat }}\right)=0.008095 \times 10^{24}$

$\mathrm{N}\left(\mathrm{B}^{\text {nat }}\right)=0.001524 \times 10^{24}$.

Self-shielding. Factor

From TEMPEST, $\sigma_{a}\left(\mathrm{~B}^{10}\right)$ at $68^{\circ} \mathrm{F}$ is 2950 barns; applying a $\sqrt{\mathrm{T}_{0} / \mathrm{T}}$ temperature correction, we get 2457 barns at $300^{\circ} \mathrm{F}$ and 2201 . barns at $489^{\circ} \mathrm{F}$.

From Ref. 44, we obtain $\mathrm{f}=0.310$ at $68^{\circ} \mathrm{F} ; \quad 0.355$ at $300^{\circ} \mathrm{F}$; 0.385 at $489^{\circ} \mathrm{F}$.

$\bar{\phi}_{\text {cell. }}$ Then,

Doing some manipulating, assume that $\bar{\phi}_{\text {pois }}=\mathrm{f} \bar{\phi}_{\mathrm{H}_{2} \mathrm{O}} ; \bar{\phi}_{\mathrm{clad}}=$

$$
\begin{aligned}
\bar{\phi}_{\text {cell }}= & \frac{\bar{\phi}_{\text {pois }} \mathrm{V}_{\text {pois }}+\bar{\phi}_{\text {clad }} \mathrm{V}_{\text {clad }}+\bar{\phi}_{\mathrm{H}_{2} \mathrm{O}} \mathrm{V}_{\mathrm{H}_{2} \mathrm{O}}}{\mathrm{V}_{\text {cell }}}=\frac{\bar{\phi}_{\mathrm{H}_{2} \mathrm{O}}\left(\mathrm{f} \mathrm{V}_{\text {pois }}+\mathrm{V}_{\mathrm{H}_{2} \mathrm{O}}\right)}{\mathrm{V}_{\text {cell }}} \\
& \cdot \frac{\mathrm{v}_{\text {cell }}}{\mathrm{V}_{\text {cell }}-\mathrm{V}_{\text {clad }}} \cdot
\end{aligned}
$$

The result is.

$$
\begin{aligned}
& \frac{{ }^{60} \mathrm{~F}}{\bar{\phi}_{\mathrm{H}_{2} \mathrm{O}}=1.170 \bar{\phi}_{\mathrm{cell}}}: \frac{300^{\circ} \mathrm{F}}{\bar{\phi}_{\mathrm{H}_{2} \mathrm{O}}=1.157 \bar{\phi}_{\mathrm{cell}}} \cdot \frac{489^{\circ} \mathrm{F}}{\bar{\phi}_{\mathrm{H}_{2} \mathrm{O}}=1.149 \bar{\phi}_{\mathrm{cell}}} \\
& \dot{\phi}_{\text {pois }}=0.363 \phi_{\text {cell }}: \bar{\phi}_{\text {pois }}=0.411 \phi_{\text {cell }} \bar{\phi}_{\text {pois }}=0.442 \bar{\phi}_{\text {cell }}
\end{aligned}
$$

These factors were used to weight the volume fractions (for thermal group) and thus the cross sections.

\begin{tabular}{|c|c|c|c|c|c|c|c|c|}
\hline $\begin{array}{c}\text { PDQ } \\
\text { Comp. } \\
\text { No. }\end{array}$ & 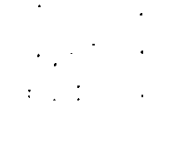 & Matèrial & 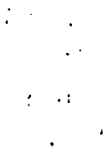 & Group & $\mathrm{D}$ & $\therefore$ & $\Sigma_{\mathbf{r}}$ & $\nu \Sigma_{f}$ \\
\hline $\begin{array}{l}13 \\
\ddots\end{array}$ & Boron-SS & $\begin{array}{c}\text { poison rod } \\
\therefore\end{array}$ & $\begin{array}{l}\cdot \\
. \\
.\end{array}$ & $\begin{array}{l}1 \\
2 \\
3 \\
4\end{array}$ & $\begin{array}{l}1.4873 \\
0.7286 \\
0.4121 \\
0.1573\end{array}$ & $\begin{array}{r}0.00051 \\
0.00948 \\
0.05067 \\
0.33864\end{array}$ & $\begin{array}{c}0.08789 \\
0.09587 \\
0.08248 \\
-\end{array}$ & \\
\hline
\end{tabular}

The cross sections were obtained from the GAM and TEMPEST problems used as the source of all the preceding constants.

1. $68^{\circ} \mathrm{F}$, No Boric Acid. (Contd.) 
2. $68^{\circ} \mathrm{F}, 5 \mathrm{~g}\left(\mathrm{H}_{3} \mathrm{BO}_{3}\right) / \mathrm{gal}\left(\mathrm{H}_{2} \mathrm{O}\right)$

\begin{tabular}{|c|c|c|c|c|c|c|c|}
\hline $\begin{array}{l}\text { PDQ } \\
\text { Comp. } \\
\text { No. }\end{array}$ & Material & $\therefore$ & Group & $\mathrm{D}$ & $\Sigma_{a}$ & $\Sigma_{\mathbf{r}}$ & $\nu \Sigma_{f}$ \\
\hline 1 & Reflector water & & $\begin{array}{l}1 \\
2 \\
3 \\
4\end{array}$ & $\begin{array}{l}1.9914 \\
1.0580 \\
0.6051 \\
0.1590\end{array}$ & $\begin{array}{l}0.00058 \\
0.00001 \\
0.00145 \\
0.02766\end{array}$ & $\begin{array}{c}0.10646 \\
0.14653 \\
0.14164 \\
.\end{array}$ & . \\
\hline 2 & Water a round boilers & $\cdot$ & $\begin{array}{l}1 \\
2 \\
3 \\
4\end{array}$ & $\begin{array}{l}1.7166 \\
0.8456 \\
0.6157 \\
0.1582\end{array}$ & $\begin{array}{l}0.00047 \\
0.00001 \\
0.00131 \\
0.02348\end{array}$ & $\begin{array}{c}0.11435 \\
0.14702 \\
0.12682 \\
-\end{array}$ & \\
\hline 3 & $\begin{array}{l}\text { Water around superheater } \\
\text { Superheater drained }\end{array}$ & : & $\begin{array}{l}1 \\
2 \\
3 \\
4\end{array}$ & $\begin{array}{l}1.6732 \\
0.8517 \\
0.6225 \\
0.1711\end{array}$ & $\begin{array}{l}0.00043 \\
0.00001 \\
0.00130 \\
0.02162\end{array}$ & $\begin{array}{l}0.11843 \\
0.14366 \\
0.12458 \\
-\end{array}$ & \\
\hline 4 & Aluminum & $\therefore$ & $\begin{array}{l}1 \\
2 \\
3 \\
4\end{array}$ & $\begin{array}{l}2.5497 \\
1.5453 \\
3.3812 \\
3.378\end{array}$ & $\begin{array}{l}0.00025 \\
0.00048 \\
0.00077 \\
0.01160\end{array}$ & $\begin{array}{c}0.01470 \\
0.00084 \\
0.00054 \\
\cdots\end{array}$ & \\
\hline$\therefore$ & $\begin{array}{l}\text { Poison section of } \\
\text { control rod }\end{array}$ & & $\begin{array}{l}1 \\
\cdot 2 \\
3 \\
4\end{array}$ & $\begin{array}{l}1.9562 * \\
1.0557^{*} \\
0.3526 * * \\
0.0095 * *\end{array}$ & $\begin{array}{l}0.00310 \\
0.03864 \\
0.77844 \\
6.89300\end{array}$ & - & \\
\hline 6 & $\begin{array}{l}\text { Aluminum-stainless steel } \\
\text { control-rod poison clad }\end{array}$ & . & $\begin{array}{l}1 \\
2 \\
3 \\
4\end{array}$ & $\begin{array}{l}0.9069 \\
0.9288 \\
0.4545 \\
0.4161\end{array}$ & $\begin{array}{l}0.00024 \\
0.00116 \\
0.01052 \\
0.14590\end{array}$ & $\begin{array}{l}0.02615 \\
0.00286 \\
0.00208\end{array}$ & \\
\hline 7 & $\begin{array}{l}\text { Aluminum-water. } \\
\text { Box, water, shroud, water }\end{array}$ & & $\begin{array}{l}1 \\
2 \\
3 \\
4\end{array}$ & $\begin{array}{l}2.1223 \\
1.1518 \\
1.1946 \\
0.3914\end{array}$ & $\begin{array}{l}0.00035 \\
0.00028 \\
0.00100 \\
0.01606\end{array}$ & $\begin{array}{c}0.05627 \\
0.16181 \\
0.05321 \\
-\end{array}$ & \\
\hline 8 & $\begin{array}{l}\text { Aluminum-water } \\
\text { Box, wate } \mathbf{r}\left(\frac{1}{2} \mathrm{H}_{2} \mathrm{O}\right)\end{array}$ & 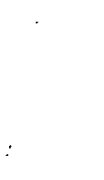 & $\begin{array}{l}1 \\
2 \\
3 \\
4\end{array}$ & $\begin{array}{l}2.0529 \\
1.0951 \\
1.0532 \\
0.3023\end{array}$ & $\begin{array}{l}0.00036 \\
0.00024 \\
0.00104 \\
0.01754\end{array}$ & $\begin{array}{c}0.06458 \\
0.07401 \\
0.06375 \\
-\end{array}$ & . \\
\hline .9 & $\begin{array}{l}\text { Stainless steel, void } \\
\text { Superheater box, insulato } \\
\text { void. ( } \frac{1}{2} \text { SS). Superheater dr }\end{array}$ & ained & $\begin{array}{l}1 \\
2 \\
3 \\
4\end{array}$ & $\begin{array}{l}3.2987 \\
1.6218 \\
0.7003 \\
0.6390\end{array}$ & $\begin{array}{l}0.00012 \\
0.00069 \\
0.00685 \\
0.08974\end{array}$ & $\begin{array}{c}0.01504 \\
0.00242 \\
0.00810 \\
-\end{array}$ & . \\
\hline 10 & $\begin{array}{l}\text { Stainless steel, water } \\
\text { Superheater box end, wate } \\
\text { Superheater drained }\end{array}$ & & $\begin{array}{l}1 \\
2 \\
3 \\
4\end{array}$ & $\begin{array}{l}2.1033 \\
1.0277 \\
0.5031 \\
0.3151\end{array}$ & $\begin{array}{l}0.00024 \\
0.00077 \\
0.00794 \\
0.10 .317\end{array}$ & $\begin{array}{c}0.04637 \\
0.03806 \\
0.03273 \\
-\end{array}$ & \\
\hline 11 & $\begin{array}{l}\text { Boiler fuel } \\
\text { a. GAM No. } 139 \text { for } \mathrm{U}^{238}\end{array}$ & & $\begin{array}{l}1 \\
2 \\
3 \\
4\end{array}$ & $\begin{array}{l}1.8337 \\
0.9744 \\
0.5640 \\
0.1898\end{array}$ & $\begin{array}{r}0.00394 \\
0.00292 \\
0.03104 \\
0.17677\end{array}$ & $\begin{array}{c}0.08830 \\
0.09184 \\
0.07511 \\
-\end{array}$ & $\begin{array}{l}0.00815 \\
0.00162 \\
0.02454 \\
0.28874\end{array}$ \\
\hline
\end{tabular}


2. $68^{\circ} \mathrm{F}, 5 \mathrm{~g}\left(\mathrm{H}_{3} \mathrm{BO}_{3}\right) / \mathrm{gal}\left(\mathrm{H}_{2} \mathrm{O}\right)$ (Contd.)

\begin{tabular}{|c|c|c|c|c|c|c|}
\hline $\begin{array}{c}\text { PDQ } \\
\text { Comp. } \\
\text { No. }\end{array}$ & Material & Group & $\mathrm{D}$ & $\Sigma_{\mathrm{a}}$ & $\Sigma_{\mathbf{r}}$ & $\nu \Sigma_{\mathbf{f}}$ \\
\hline \multirow[t]{4}{*}{11} & b. GAM No. 12 for $U^{238}$ & 1 & 1.6821 & 0.00386 & 0.08847 & 0.00840 \\
\hline & & 2 & 0.8632 & 0.00178 & 0.09257 & 0.00161 \\
\hline & & 3 & 0.5273 & 0.03122 & 0.07971 & 0.02511 \\
\hline & & 4 & 0.1898 & 0.17677 & - & 0.28874 \\
\hline \multirow[t]{4}{*}{12} & Superheater fuel & 1 & 3.8008 & 0.00120 & 0.01287 & 0.00304 \\
\hline & Superheater drained & 2 & 1.9301 & 0.00231 & 0.00140 & 0.00384 \\
\hline & & 3 & 0.7999 & 0.04443 & 0.00102 & 0.05993 \\
\hline & & 4 & 0.4312 & 0.43235 & - & 0.7516 \\
\hline \multirow[t]{4}{*}{13} & Boron-SS poison rod & 1 & 1.4873 & 0.00051 & 0.08789 & \\
\hline & & 2 & 0.7286 & 0.00949 & 0.09587 & \\
\hline & & 3 & 0.4121 & 0.05092 & 0.09248 & \\
\hline & ' & 4 & 0.1573 & 0.34376 & - & \\
\hline
\end{tabular}

*From homogenized boiler.

**From blackness.

3. $68^{\circ} \mathrm{F}, 10 \mathrm{~g}\left(\mathrm{H}_{3} \mathrm{BO}_{3}\right) / \mathrm{gal}\left(\mathrm{H}_{2} \mathrm{O}\right)$

$1 \quad$ Reflector water

2 Water a round boiler

3 Water around superheater Superheater drained

4 Aluminum

. 5 Poison section of control. rod

6 Al-SS control-rod cladding

7 Aluminum-water

Box, water, shroud, water
1.9911
0.00058
0.10646
1.0579
0.00002
0.14653
0.6049
0.00189
0.14133
0.1602
0.03588
0.11435
1.7164
$0: 00047$
0.8455
0.00002
0.6152
0.00172
0.1584
0.03055
0.14702
0.12682
1.6730
0.00043
0.11844
0.8516
0.00002
0.14366
0.6220
0.00171
0.12458
0.1711
0.02815
2.5497
0.00025
0.01470
1.5453
0.00048
3.3812
0.00077
0.00084
3. 3790
0.01155
0.00054
1.9562*
0.00310
$1.0557 *$
0.03864
$0.3526 * *$
0.77844
$0.0096 * *$
6.88400
0.9288
0.00024 .
0.00116
0.01052
0.02615
0.4545
0.4165
0.14520
0.00208
2. 1222
0.00035
0.05627
1. 1517
0.00029
0.06181
1. 1938
0.00117
0.01868
0.05321
0.3918
0.01868

1

$1 \quad 1.9069$ 
3. $68^{\circ} \mathrm{F}, 10 \mathrm{~g}\left(\mathrm{H}_{3} \mathrm{BO}_{3}\right) / \mathrm{gal}\left(\mathrm{H}_{2} \mathrm{O}\right)$ (Contd.)

\begin{tabular}{|c|c|c|c|c|c|c|}
\hline $\begin{array}{c}\text { PDQ } \\
\text { Comp. } \\
\text { No. }\end{array}$ & Material & Group & $\mathrm{D}$ & $\Sigma_{\mathrm{a}}$ & $\Sigma_{\mathbf{r}}$ & $\nu \Sigma_{f}$ \\
\hline 8 & $\begin{array}{l}\text { Aluminum-water } \\
\text { Box, water }\left(\frac{1}{2} \mathrm{Al}\right)\end{array}$ & $\begin{array}{l}1 \\
2 \\
3 \\
4\end{array}$ & $\begin{array}{l}2.5028 \\
1.0951 \\
1.0525 \\
0.3026\end{array}$ & $\begin{array}{l}0.00036 \\
0.00025 \\
0.00125 \\
0.02105\end{array}$ & $\begin{array}{c}0.06458 \\
0.07401 \\
0.06375 \\
-\end{array}$ & \\
\hline 9 & $\begin{array}{l}\text { Stainless steel, void } \\
\text { Superheater box, insulator } \\
\left.\text { void ( } \frac{1}{2} \mathrm{SS}\right) \\
\text { Superheater drained }\end{array}$ & $\begin{array}{l}1 \\
2 \\
3 \\
4\end{array}$ & $\begin{array}{l}3.2987 \\
1.6218 \\
0.7003 \\
0.6394\end{array}$ & $\begin{array}{l}0.00012 \\
0.00069 \\
0.00685 \\
0.08943\end{array}$ & $\begin{array}{l}0.01504 \\
0.00242 \\
0.00810 \\
-\end{array}$ & \\
\hline 10 & $\begin{array}{l}\text { Stainless steel-water } \\
\text { Superlueater box end, water } \\
\text { Superheater drained }\end{array}$ & $\begin{array}{l}1 \\
2 \\
3 \\
4\end{array}$ & $\begin{array}{l}2.1032 \\
1.0276 \\
0.5030 \\
0.3151\end{array}$ & $\begin{array}{l}0.00024 \\
0.00077 \\
0.00804 \\
0.10447\end{array}$ & $\begin{array}{c}0.04637 \\
0.03806 \\
0.03273 \\
-\end{array}$ & . \\
\hline 11 & $\begin{array}{l}\text { Boiler fuel } \\
\text { a. GAM No. } 139 \text { for } \mathrm{U}^{238}\end{array}$ & $\begin{array}{l}1 \\
2 \\
3 \\
4\end{array}$ & $\begin{array}{l}1.8335 \\
0.9743 \\
0.5637 \\
0.1900\end{array}$ & $\begin{array}{l}0.00394 \\
0.00292 \\
0.03130 \\
0.18102\end{array}$ & $\begin{array}{c}0.08830 \\
0.09184 \\
0.07511 \\
-\end{array}$ & $\begin{array}{l}0.00815 \\
0.00162 \\
0.02454 \\
0.28749\end{array}$ \\
\hline$\because$ & b. GAM No. 12 for $\mathrm{U}^{238}$ & $\begin{array}{l}1 \\
2 \\
3 \\
4\end{array}$ & $\begin{array}{l}1.6820 \\
0.8631 \\
0.5271 \\
0.1900\end{array}$ & $\begin{array}{l}0.00387 \\
0.00179 \\
0.03148 \\
0.18102\end{array}$ & $\begin{array}{c}0.08847 \\
0.09257 \\
0.07971 \\
-\end{array}$ & $\begin{array}{l}0.00840 \\
0.00161 \\
0.02511 \\
0.28749\end{array}$ \\
\hline 12 & $\begin{array}{l}\text { Superheater fuel } \\
\text { Superheater drained }\end{array}$ & $\begin{array}{l}1 \\
2 \\
3 \\
4\end{array}$ & $\begin{array}{l}3.8008 \\
1.9301 \\
0.7999 \\
0.4318\end{array}$ & $\begin{array}{l}0.00120 \\
0.00231 \\
0.04443 \\
0.43118\end{array}$ & $\begin{array}{c}0.01287 \\
0.00140 \\
0.00102 \\
-\end{array}$ & $\begin{array}{l}0.00304 \\
0.00384 \\
0.05993 \\
0.74866\end{array}$ \\
\hline 13 & Boron-SS poison rod & $\begin{array}{l}1 \\
2 \\
3 \\
4\end{array}$ & $\begin{array}{l}1.4873 \\
0.7286 \\
0.4121 \\
0.1573\end{array}$ & $\begin{array}{l}0.00051 \\
0.00949 \\
0.05118 \\
0.34885\end{array}$ & $\begin{array}{c}0.08789 \\
0.09587 \\
0.08248 \\
=\end{array}$ & . \\
\hline
\end{tabular}

*From homogenized boiler.

**From blackness.

4. $68^{\circ} \mathrm{F}, 15 \mathrm{~g}\left(\mathrm{H}_{3} \mathrm{BO}_{3}\right) / \mathrm{gal}\left(\mathrm{H}_{2} \mathrm{O}\right)$

1 Reflector water

0.00058

0.10646

1.0578

0.00002

0.14653

0.6047

0.00234

0.14101

4

0.1614

0.04399

2 Watèr around boilers

1.7162

0.00048

0.11482

0.8453

0.00002

0.14705

0.6147

0.00213

0.12896

3 Water around superheater

0.1585

0.03755

$=$

$1 \quad .6728$

0.00043

0.11844

Superheater drained

0.8515

0.00002

0.14366

$3 \quad 0.6215$

0.00211

0.12458

$0.1711 \quad 0.03465$ 
4. $68^{\circ} \mathrm{F}, 15 \mathrm{~g}\left(\mathrm{H}_{3} \mathrm{BO}_{3}\right) / \mathrm{gal}\left(\mathrm{H}_{2} \mathrm{O}\right)$ (Contd.)

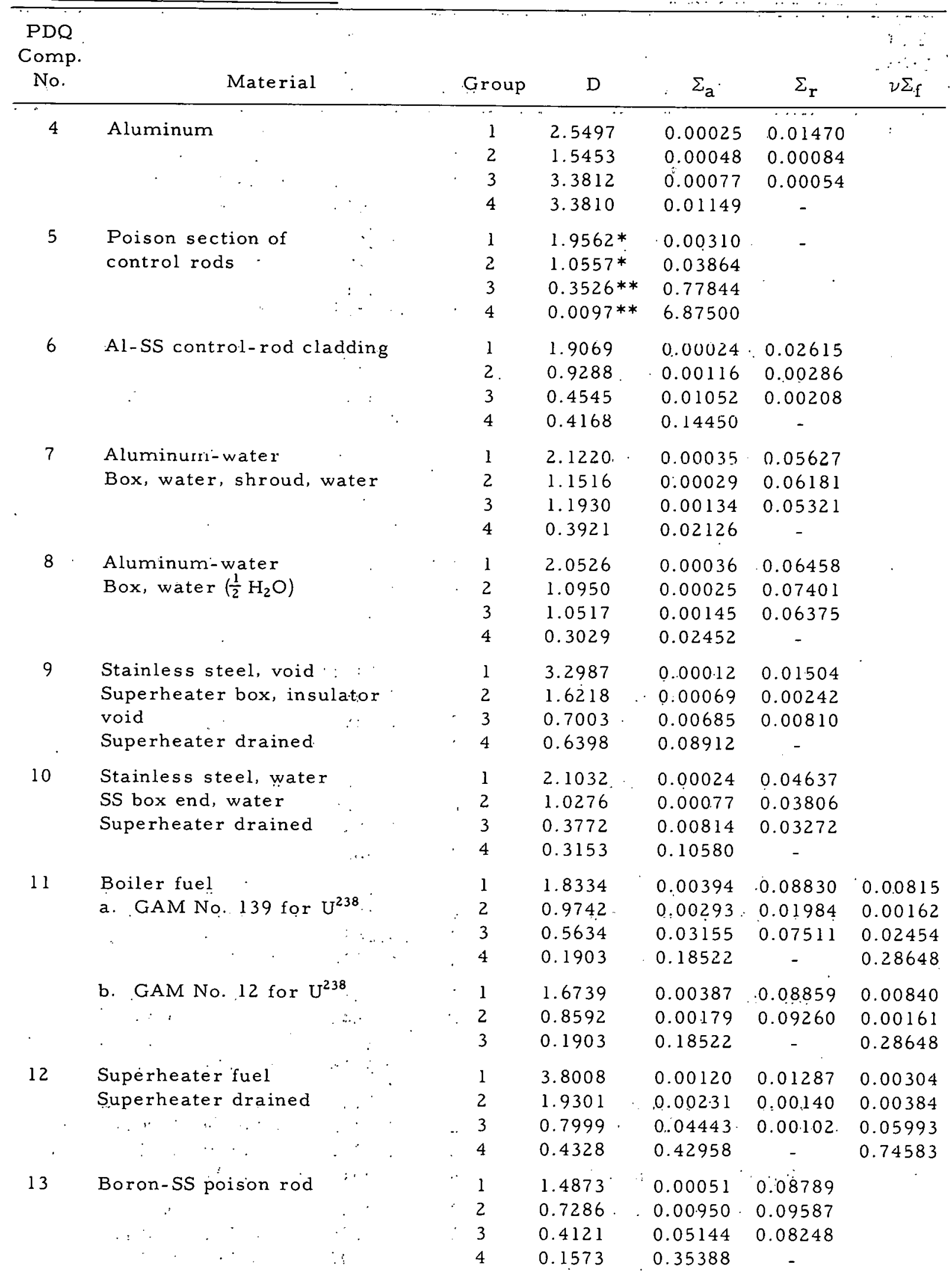

\footnotetext{
*From homogenized boiler.
}

**From blackness. 
5. $300^{\circ} \mathrm{F}$, No Boric Acid

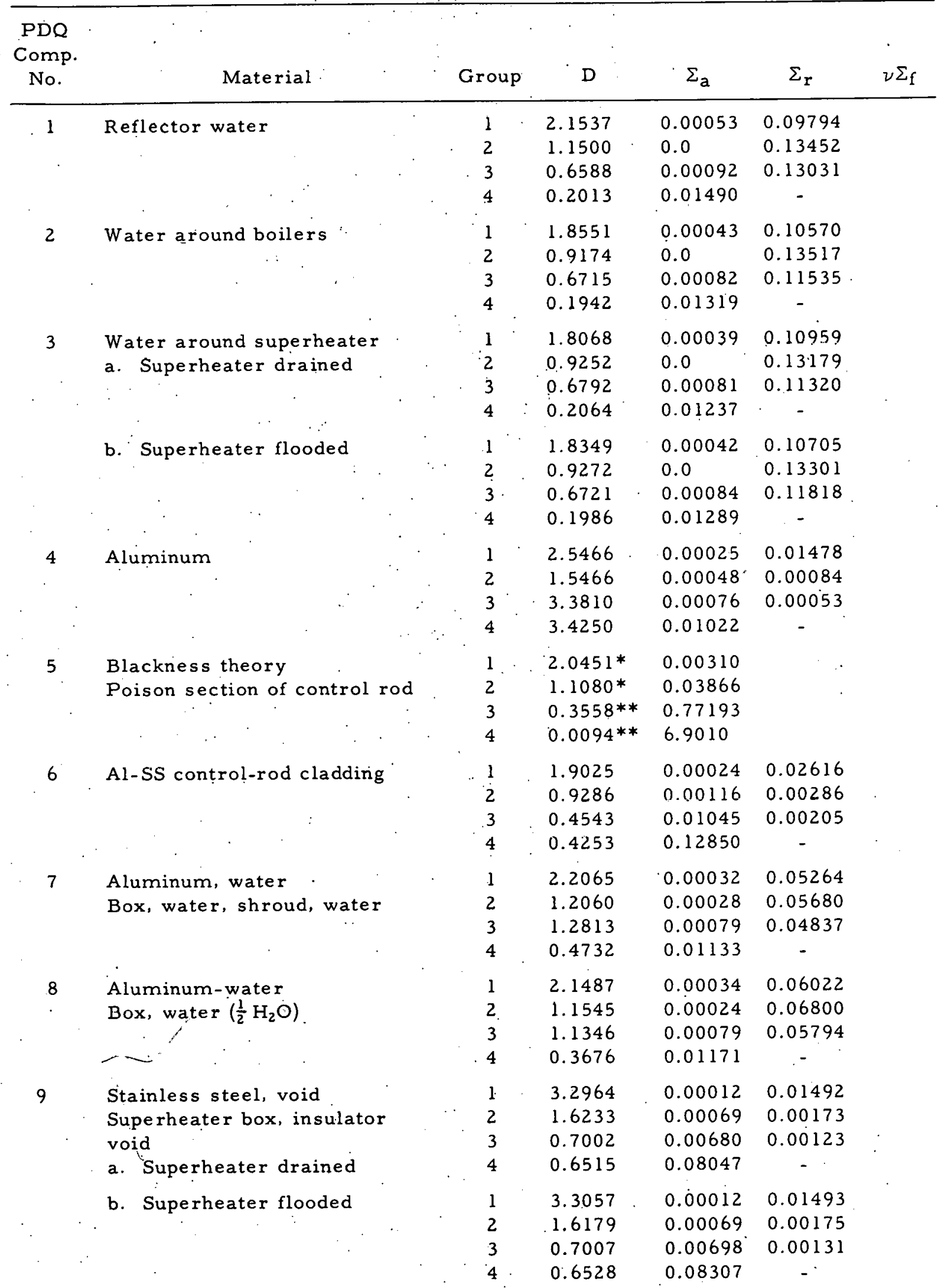


5. $300^{\circ} \mathrm{F}$, No Boric Acid (Contd.)

\begin{tabular}{|c|c|c|c|c|c|c|c|}
\hline $\begin{array}{l}\text { PDQ } \\
\text { Comp. } \\
\text { No. }\end{array}$ & Material & & Group & $\mathrm{D}$ & $\Sigma_{\mathbf{a}}$ & $\Sigma_{\mathrm{r}}$ & $\nu \Sigma_{\mathrm{f}}$ \\
\hline \multirow[t]{8}{*}{10} & \multirow{2}{*}{\multicolumn{2}{|c|}{$\begin{array}{l}\text { Stainiess steel, water } \\
\text { Superheater box end, water }\end{array}$}} & 1 & 2.1526 & 0.00023 & $0.04414^{\circ}$ & \\
\hline & & & 2 & 1.0538 & 0.00076 & 0.03507 & \\
\hline & \multirow{2}{*}{\multicolumn{2}{|c|}{ a: Superheater drained }} & 3 & 0.5117 & 0.00776 & 0.02984 & \\
\hline & & & 4 & 0.3456 & 0.09089 & - & \\
\hline & \multirow[t]{4}{*}{ b. Superheater flooded } & \multirow[t]{4}{*}{. } & 1 & 1.8611 & 0.00030 & 0.05911 & 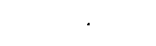 \\
\hline & & & 2 & 0.9049 & 0.00077 & 0.05477 & \\
\hline & & & 3 & 0.4603 & 0.00809 & 0.04838 & \\
\hline & & & 4 & 0.2714 & 0.09651 & - & \\
\hline \multirow[t]{8}{*}{11} & \multirow{2}{*}{\multicolumn{2}{|c|}{$\begin{array}{l}\text { Boiler fuel } \\
\text { a. GAM No. } 139 \text { for } \mathrm{U}^{238}\end{array}$}} & 1 & 1.9167 & 0.00390 & 0.08296 & 0.00813 \\
\hline & & & 2 & 1.0217 & 0.00291 & 0.08447 & 0.00162 \\
\hline & $\cdot$ & \multirow{6}{*}{ 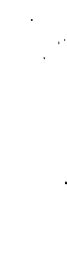 } & 3 & 0.5932 & 0.03083 & 0.06804 & 0.02438 \\
\hline & & & 4 & 0.2285 & 0.15176 & - & 0.25594 \\
\hline & b. GAM No. 12 for $\mathrm{U}^{238}$ & & 1 & 1.7616 & 0.00383 & 0.08312 & 0.00836 \\
\hline & & & 2 & 0.9084 & 0.00177 & 0.08519 & 0.00161 \\
\hline & $\cdot$ & & 3 & 0.5518 & 0.03112 & 0.07256 & 0.02500 \\
\hline & . & & 4 & 0.2285 & 0.15176 & - & 0.25594 \\
\hline \multirow[t]{6}{*}{12} & \multirow{4}{*}{\multicolumn{2}{|c|}{$\begin{array}{l}\text { Superheater fuel } \\
\text { a. Superheater flooded }\end{array}$}} & 1 & 1.7810 & 0.00145 & $0.07561^{\circ}$ & 0.00305 \\
\hline & & & 2 & $0.8790^{\circ}$ & 0.00231 & 0.07938 & 0.00384 \\
\hline & & & 3 & 0.4724 & 0.04546 & 0.07034 & 0.06059 \\
\hline & & & 4 & 0.1947 & 0.39825 & - & 0.67662 \\
\hline & \multirow{3}{*}{\multicolumn{2}{|c|}{ b. Superheater drained }} & 1 & 3.7860 & 0.00120 & 0.01305 & 0.00303 \\
\hline & & & 2 & 1.9255 & $0: 00230$ & 0.00162 & 0.00383 \\
\hline & & & 3 & 0.7985 & 0.04429 & 0.00119 & 0.05967 \\
\hline & & $\cdot$ & 4 & 0.4611 & 0.38284 & - & 0.66269 \\
\hline \multirow[t]{4}{*}{13} & \multirow[t]{4}{*}{ Boron-SS poison rod } & & 1 & 1.5516 & 0.00048 & 0.08234 & \\
\hline & & & 2 & 0.7615 & 0.00948 & 0.0882 .7 & . \\
\hline & & & 3 & 0.4273 & 0.05062 & 0.07513 & \\
\hline & & & 4 & 0.1850 & 0.31634 & - & \\
\hline
\end{tabular}

*From homogenized builex.

**From blackness.

6. $489^{\circ} \mathrm{F}$, No Boric Acid, Zero Power

1 Reflector water

2 Water around boilers

Wate $r$ a round superheater a. Superheater drained

1
2
3
4
1
2

2.4748

1.3359

0.7678

0.2587

2.1345

1.0646

0.7859

0.2466

2.0773

1.0762

0.7956

0.2596
0.00045

0.0

0.00079

0.01148

0.00036

0.0

0.00069

0.01033

0.00032

0.0

0.00068

0.00979
0.08428

0.11518

0.11157

0.09156

0.11588

0.09688

0.09502

0.11253

0.09493 
6. $489^{\circ} \mathrm{F}$, No Boric Acid, Zero Power (Contd.)

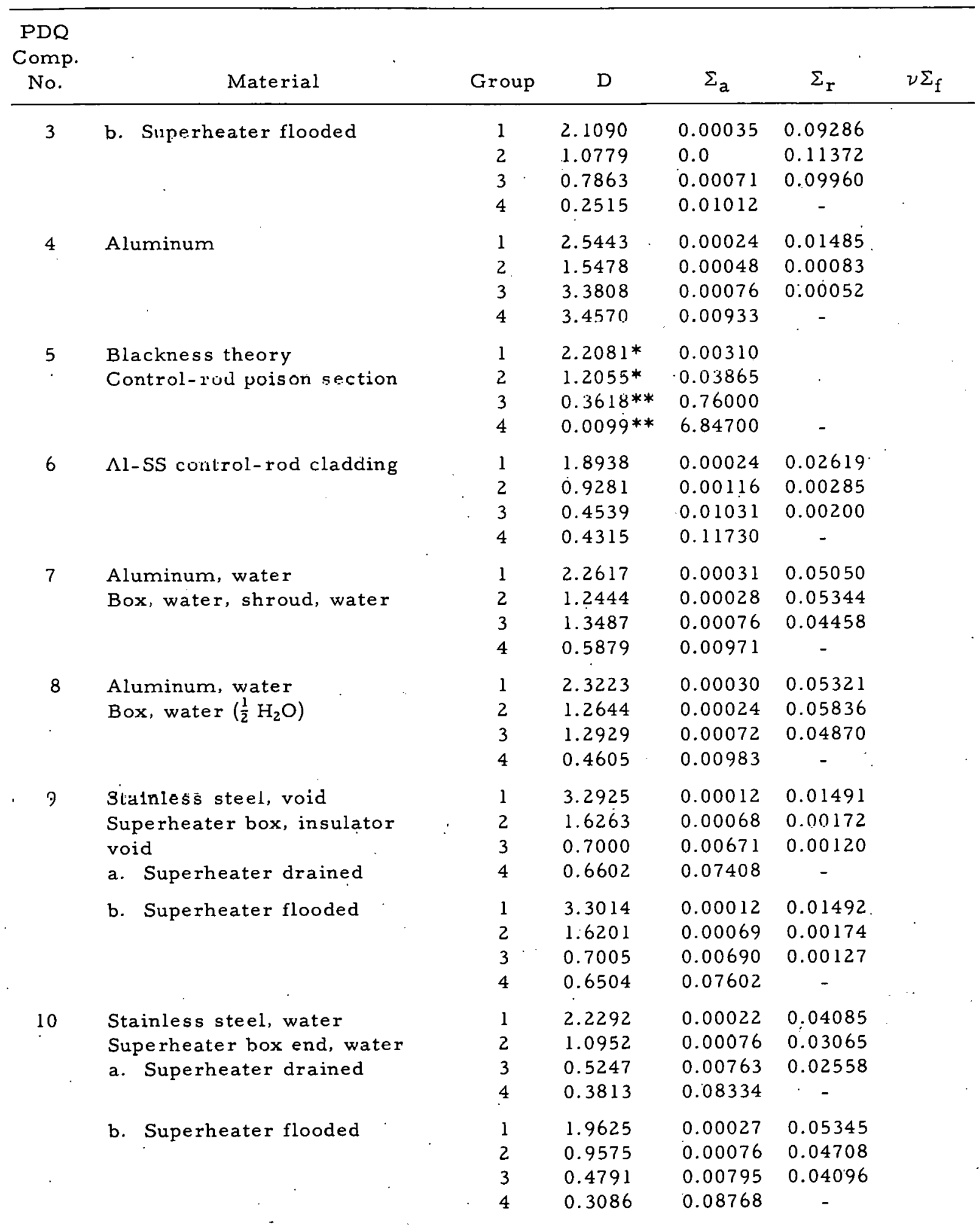


6. $489^{\circ} \mathrm{F}$, No Boric Acid, Zero Power (Contd.).

\begin{tabular}{|c|c|c|c|c|c|c|}
\hline $\begin{array}{c}\text { PDQ } \\
\text { Comp. } \\
\text { No. }\end{array}$ & Material & Group & $\mathrm{D}$ & $\Sigma_{\mathrm{a}}$ & $\Sigma_{r}$ & $\nu \Sigma_{\mathrm{f}}$ \\
\hline \multirow[t]{8}{*}{11} & Boiler fuel & 1 & 2.0686 & 0.00384 & 0.07424 & 0.00808 \\
\hline & a. GAM No. 139 for $\mathrm{U}^{238}$ & 2 & 1.1094 & 0.00291 & 0.07247 & 0.00162 \\
\hline & & 3 & 0.6476 & 0.03033 & 0.05673 & 0.02409 \\
\hline & . & 4 & 0.2796 & 0.13819 & - & 0.23451 \\
\hline & b. GAM No. 12 for $U^{238}$ & 1 & 1.9078 & 0.00376 & 0.07438 & 0.00830 \\
\hline & & 2 & 0.9929. & 0.00177 & 0.07317 & 0.00161 \\
\hline & & 3 & 0.5967 & 0.03074 & 0.06103 & 0.02479 \\
\hline & - & 4 & 0.2796 & 0.13819 & - & 0.23451 \\
\hline \multirow[t]{8}{*}{12} & Superheater fuel & 1 & 1.9221 & 0.00140 & 0.06729 & 0.00304 \\
\hline & a. Superheater flooded & 2 & 0.9535 & 0.00231 & 0.06806 & 0.00384 \\
\hline & & 3 & 0.5025 & 0.04512 & 0.05942 & 0.06020 \\
\hline & . & 4 & 0.2262 & 0.36216 & - & 0.61486 \\
\hline & b. Superheater dráined & 1 & 3.6984 & 0.00121 & 0.01438 & 0.00303 \\
\hline & & 2 & 1.8849 & 0.00230 & 0.00317 & 0.00383 \\
\hline & & 3 & 0.7880 & 0.04396 & 0.00248 & 0.05918 \\
\hline & & 4 & 0.4695 & 0.35035 & - & 0.60385 \\
\hline \multirow[t]{4}{*}{13} & Boron-SS poison rod & 1 & 1.6687 & 0.00043 & 0.07328 & \\
\hline & & 2 & 0.8220 & 0.00948 & 0.07590 & \\
\hline & & 3 & 0.4542 & 0.05053 & 0.06329 & \\
\hline & & 4 & 0.2198 & 0.30183 & - & \\
\hline
\end{tabular}

*From homogenized boiler.

**From blackness.

7. $489^{\circ} \mathrm{F}$, No Boric Acid, $10 \%$ Void in Boiler Fuel Region, Boiler Fuel Temp: $900^{\circ} \mathrm{F}$

1 Reflector water

2 Water around boilers

3 Water around superheater

4 Aluminum
2.4748

1.3359

0.7678

0.2587

2. 1295

1.0634

0.7879

0.2479

2.0773

1.0762

0.7956

0.2596

2.5429

1.5485

3. 3807

3.4590
0.00045

0.0

0.00079

0.01148

0.00035

0.0

0.00068

0.01028

0.00032

0.0

0.00068

0.00979

0.00024

0.00048

0.00075

0.00928
0.08428

0.11518

0.11157

0.09191

0.11583

0.09587

0.09502

0.11253

0.09493

0.01490

0.00083

0.00051 
7. $489^{\circ} \mathrm{F}$, No Boric Acid, $10 \%$ Void in Boiler Fuel Region, Boiler Fuel Temp: $900^{\circ} \mathrm{F}$ (Contd.)

\begin{tabular}{|c|c|c|c|c|c|c|c|}
\hline $\begin{array}{l}\text { PDQ } \\
\text { Comp. } \\
\text { No. }\end{array}$ & Material & & Group & $\mathrm{D}$ & $\Sigma_{\mathrm{a}}$ & $\sum_{\mathbf{r}}$ & $\nu \Sigma_{\mathrm{f}}$ \\
\hline 5 & $\begin{array}{l}\text { Blackness theory } \\
\text { Control-rod poison section }\end{array}$ & & $\begin{array}{l}1 \\
2 \\
3 \\
4\end{array}$ & $\begin{array}{l}2.2718^{*} \\
1.2441^{*} \\
0.3649^{*} * \\
0.0099^{*} *\end{array}$ & $\begin{array}{l}0.00310 \\
0.03865 \\
0.75406 \\
6.84700\end{array}$ & . & \\
\hline 6 & Al-SS control-rod cladding & & $\begin{array}{l}1 \\
2 \\
3 \\
4\end{array}$ & $\begin{array}{l}1.8902 \\
0.9278 \\
0.4537 \\
0.4296\end{array}$ & $\begin{array}{l}0.00024 \\
0.00116 \\
0.01025 \\
0.12070\end{array}$ & $\begin{array}{l}0.02620 \\
0.00285 \\
0.00198 \\
-\end{array}$ & \\
\hline 7 & $\begin{array}{l}\text { Aluminum, water } \\
\text { Box, water, shroud, water }\end{array}$ & & $\begin{array}{l}1 \\
2 \\
3 \\
1\end{array}$ & $\begin{array}{l}2.2586 \\
1.2438 \\
1.3514 \\
0.5903\end{array}$ & $\begin{array}{l}0.00030 \\
0.00028 \\
0.00075 \\
0.00966\end{array}$ & $\begin{array}{l}0.05069 \\
0.05342 \\
0.04411 \\
-\end{array}$ & \\
\hline 8 & $\begin{array}{l}\text { Aluminum, water } \\
\text { Box, water }\left(\frac{1}{2} \mathrm{H}_{2} \mathrm{O}\right)\end{array}$ & $\cdot$ & $\begin{array}{l}1 \\
2 \\
3 \\
4\end{array}$ & $\begin{array}{l}2.3187 \\
1.2638 \\
1.2956 \\
0.4624\end{array}$ & $\begin{array}{l}0.00030 \\
0.00024 \\
0.00072 \\
0.00978\end{array}$ & $\begin{array}{c}0.05340 \\
0.05833 \\
0.04819 \\
-\end{array}$ & \\
\hline 9 & $\begin{array}{l}\text { Stainless steel, void } \\
\text { Superheater box, insulator } \\
\text { void }\end{array}$ & & $\begin{array}{l}1 \\
2 \\
3 \\
4\end{array}$ & $\begin{array}{l}3.2925 \\
1.6263 \\
0.7000 \\
0.6602\end{array}$ & $\begin{array}{l}0.00012 \\
0.00068 \\
0.00671 \\
0.07408\end{array}$ & $\begin{array}{c}0.01491 \\
0.00172 \\
0.00120 \\
-\end{array}$ & . \\
\hline 10 & $\begin{array}{l}\text { Stainless steel, water } \\
\text { Superheater box end, water }\end{array}$ & & $\begin{array}{l}1 \\
2 \\
3 \\
4\end{array}$ & $\begin{array}{l}2.2292 \\
1.0952 \\
0.5247 \\
0.3813\end{array}$ & $\begin{array}{l}0.00022 \\
0.00076 \\
0.00763 \\
0.08334\end{array}$ & $\begin{array}{c}0.04085 \\
0.03065 \\
0.02558 \\
-\end{array}$ & . \\
\hline 11 & $\begin{array}{l}\text { Boiler fuel } \\
\text { a. GAM No. } 139 \text { for } \mathrm{U}^{238}\end{array}$ & & $\begin{array}{l}1 \\
2 \\
3 \\
4\end{array}$ & $\begin{array}{l}2.1725 \\
1.1704 \\
0.6859 \\
0.3042\end{array}$ & $\begin{array}{l}0.00380 \\
0.00290 \\
0.03029 \\
0.13699\end{array}$ & $\begin{array}{c}0.06894 \\
0.06520 \\
0.04983 \\
-\end{array}$ & $\begin{array}{l}0.00804 \\
0.00162 \\
0.02385 \\
0.23358\end{array}$ \\
\hline . & b. GAM No. 12 for $\mathrm{U}^{238}$ & & $\begin{array}{l}1 \\
2 \\
3 \\
4\end{array}$ & $\begin{array}{l}2.0111 \\
1.0528 \\
0.6269 \\
0.3042\end{array}$ & $\begin{array}{l}0.00373 \\
0.00176 \\
0.03090 \\
0.13699\end{array}$ & $\begin{array}{c}0.06890 \\
0.06592 \\
0.05442 \\
-\end{array}$ & $\begin{array}{l}0.00828 \\
0.00161 \\
0.02469 \\
0.23358\end{array}$ \\
\hline 12 & $\begin{array}{l}\text { Superheater fuel } \\
\text { Superheater drained }\end{array}$ & & $\begin{array}{l}1 \\
2 \\
3 \\
4\end{array}$ & $\begin{array}{l}3.6984 \\
1.8849 \\
0.7880 \\
0.4695\end{array}$ & $\begin{array}{l}0.00121 \\
0.00230 \\
0.04396 \\
0.35035\end{array}$ & $\begin{array}{c}0.01438 \\
0.00317 \\
0.00248 \\
-\end{array}$ & $\begin{array}{l}0.00303 \\
0.00383 \\
0.05918 \\
0.60385\end{array}$ \\
\hline 13 & Boron-SS poison rod & & $\begin{array}{l}1 \\
2 \\
3 \\
4\end{array}$ & $\begin{array}{l}1.7568 \\
0.8648 \\
0.4717 \\
0.2360\end{array}$ & $\begin{array}{l}0.00041 \\
0.00948 \\
0.05049 \\
0.30083\end{array}$ & $\begin{array}{c}0.06741 \\
0.06847 \\
0.05707 \\
.\end{array}$ & \\
\hline
\end{tabular}

*From. homogenized boiler.

**From blackness. 
8. a. 49-fuel-rod Boiler, $68^{\circ} \mathrm{F}$, No Boric Acid, Homogenized over 3.375 in. sq.

\begin{tabular}{|c|c|c|c|c|c|c|c|c|}
\hline $\begin{array}{c}\text { PDQ } \\
\text { Comp. } \\
\text { No. }\end{array}$ & Material & . & . & Group & $\dot{\mathrm{D}}$ & $\Sigma_{\mathrm{a}}$ & $\Sigma_{\mathbf{r}}$ & $\nu \Sigma_{f}$ \\
\hline & & & & 1 & 1.7798 & 0.00501 & 0.08459 & 0.01065 \\
\hline & & & & 2 & 0.9480 & 0.00385 & 0.07872 & 0.00214 \\
\hline & . & & $\ldots$ & 3 & 0.5480 & 0.03831 & 0.05929 & 0.03148 \\
\hline & & & & 4 & 0.2045 & 0.22990 & - & 0.39654 \\
\hline
\end{tabular}

b. 49-fuel-rod Boiler, $489^{\circ} \mathrm{F}$, No Boric Acid, Homogenized over 3. 375 in. sq.

$\begin{array}{cccc}1.9654 & 0.00491 & 0.07246 & 0.01054 \\ 1.0561 & 0.00384 & 0.06220 & 0.00214 \\ 0.6149 & 0.03738 & 0.04405 & 0.03070 \\ 0.2935 & 0.18369 & - & 0.31787\end{array}$




\section{APPENDIX F}

Four-group Homogenized-fuel-region Constants from PDQ- 3 for Axial Control-rod-worth Calculations, Superheaters Drained, $68^{\circ} \mathrm{F}$

1. No Boric Acid

a. Control Rods In

\begin{tabular}{|c|c|c|c|c|c|}
\hline Group & $\mathrm{D}$ & $\Sigma_{\mathrm{a}}$ & $\Sigma_{\mathbf{r}}$ & $\nu \Sigma_{\mathrm{f}}$ & $\mathrm{B}_{\mathrm{r}}^{2}$ \\
\hline 1 & 2.0141 & 0.00369 & 0.08139 & 0.00769 & 0.03670 \\
\hline 2 & 1.0612 & 0.00286 & 0.08363 & 0.00182 & 0.02620 \\
\hline 3 & 0.5850 & 0.03199 & 0.06858 & 0.02766 & 0.00420 \\
\hline 4 & 0.2045 & 0.18876 & - & 0.31888 & -0.27427 \\
\hline \multicolumn{6}{|c|}{ b: Control Rods Out } \\
\hline 1 & 2.0294 & 0.00367 & 0.08080 & 0.00765 & 0.03820 \\
\hline 2 & 1.067 .9 & 0.00285 & 0.08300 & 0.00183 & 0.02591 \\
\hline 3 & 0.5865 & 0.03208 & 0.06811 & 0.02788 & -0.01298 \\
\hline 4 & 0.2068 & 0.19132 & - & 0.32343 & -0.38438 \\
\hline
\end{tabular}

2. $\left.\left.5 \mathrm{~g}\left(\mathrm{H}_{3} \mathrm{BO}_{3}\right) / \mathrm{gal}\right) \mathrm{H}_{2} \mathrm{O}\right)$

a. Control Rods In

$\begin{array}{lrrrrr}1 & 2.0160 & 0.00369 & 0.08131 & 0.00768 & 0.03660 \\ 2 . & 1.0620 & 0.00286 & 0.08355 & 0.00182 & 0.02611 \\ 3 & 0.5849 & 0.03223 & 0.06853 & 0.02768 & 0.00411 \\ 4 & 0.2051 & 0.19301 & - & 0.31814 & -0.27056\end{array}$

b. Control Kods Uut

$\begin{array}{rrrccr}1 & 2.0287 & 0.00367 & 0.08082 & 0.00765 & 0.03800 \\ 2 & 1.0676 & 0.00286 & 0.08302 & 0.00183 & 0.02759 \\ 3 & 0.5862 & 0.03230 & 0.06813 & 0.02787 & -0.01298 \\ 4 & 0.2071 & 0.19507 & - & 0.32187 & -0.37805\end{array}$

3. $\frac{10 \mathrm{~g}\left(\mathrm{H}_{3} \mathrm{BO}_{3}\right) / \mathrm{gal}\left(\mathrm{H}_{2} \mathrm{O}\right)}{\mathrm{ContrOl}}$

a. Control Rods In

$\begin{array}{rrrccr}1 & 2.0177 & 0.00369 & 0.08124 & 0.00768 & 0.03657 \\ 2 & 1.0627 & 0.00287 & 0.08347 & 0.00182 & 0.02606 \\ 3 & 0.5849 & 0.03247 & 0.06847 & 0.02771 & 0.00404 \\ 4 & 0.2057 & 0.19720 & - & 0.31732 & -0.26807\end{array}$

b. Control Rods Out

$\begin{array}{rrrrrr}1 & 2.0286 & 0.00367 & 0.08082 & 0.00765 & 0.03789 \\ 2 & 1.0675 & 0.00286 & 0.08302 & 0.00183 & 0.02572 \\ 3 & 0.5860 & 0.03254 & 0.06812 & 0.02788 & -0.01299 \\ 4 & 0.2073 & 0.19893 & - & 0.32051 & -0.37333\end{array}$


107

4. $\frac{15 \mathrm{~g}\left(\mathrm{H}_{3} \mathrm{BO}_{3}\right) / \mathrm{gal}\left(\mathrm{H}_{2} \mathrm{O}\right)}{\text { a. Control Rods In }}$

\begin{tabular}{cccccr}
\hline Group & $\mathrm{D}$ & $\Sigma_{\mathrm{a}}$ & $\Sigma_{\mathrm{r}}$ & $\nu \Sigma_{\mathrm{f}}$ & \multicolumn{1}{c}{$\mathrm{B}_{\mathrm{r}}^{2}$} \\
\hline 1 & 2.0197 & 0.00368 & 0.08116 & 0.00767 & 0.03662 \\
2 & 1.0635 & 0.00287 & 0.08339 & 0.00182 & 0.02602 \\
3 & 0.5849 & 0.03272 & 0.06840 & 0.02775 & 0.00430 \\
4 & 0.2063 & 0.20133 & - & 0.31676 & -0.26833
\end{tabular}

b. Control Rods Out

\begin{tabular}{rrrrrr}
1 & 2.0291 & 0.00367 & 0.08080 & 0.00765 & 0.03787 \\
2 & 1.0677 & 0.00287 & 0.08300 & 0.00183 & 0.02565 \\
3 & 0.5858 & 0.03277 & 0.06810 & 0.02789 & -0.01263 \\
4 & 0.2077 & 0.20280 & - & 0.31950 & -0.37124 \\
\hline
\end{tabular}




\section{REFERENCES}

1. R. E. Rice et al., Proposal and Preliminary Design for the BORAX-V, ANL- 6120 (Aug. 4, 1958).

2. R. E. Rice et al., Design and Hazards Report, Boiling Reactor Experiment V (BORAX-V), ANL-6302 (May 1961).

3. R. E. Rice et al., Preliminary Design and Hazards Report, Boiling Reactor Experiment V(BORAX-V) (Feb 1960).

4. W. C. Kramer and C. H. Bean, Fabrication of $\mathrm{UO}_{2}-\mathrm{SS}$. Dispersion Fuel for BORAX-V Nuclear Superheat, ANL-6649 (Dec 1963).

5. DeWitt A. Moses, Editor, Proceedings of the Ninth Nuclear Superheat Meeting, SAN-8003 (June 1964).

6. A. R. Boynton et al., "High Conversion Critical Experiment," section of Reactor Physics Division Annual Report, July 1, 1963 to June 30, 1964, ANL-7010 (Jan 1965).

7. K. E. Plumlee et al., Critical Experiment with BORAX-V. Internal Superheater, A $\bar{N} L-669 \overline{1(N o v ~ 1963) . ~}$

8. F. S. Kirn and J. I. Hagen, BORAX-V Exponential Experiment, ANL-6707 (Apr 1963).

9. Henry Bohl et al., MUFT-IV, Fast Neutron Spectrum Code for the IBM-704, WAPD-TM-72 (July 1957)。

.10. Harvey Amster and Roland Suarez, The Calculation of Thermal Constants Averaged Over a Wigner-Wilkens Flux Spectrum, WAPD-TM-39 (Jan 1957).

11. G. D. Joanow and J. S. Dudek, GAM-I, A Consistent $P_{1}$ Multigroup Code for the Calculation of Fast Neutron Spectra and Multigroup Constants, G $\Lambda-1850$ (1961).

12. R. H. Shudde and J. Dyer, TEMPEST-II, A Neutron Thermalization Code, TID-18284 (June 1962).

13. J. A. Thie, private communication.

14. A. Amouyal, P. Benoist, and J. Horowitz, Nouvelle Methode de Determination des Facteurs $D^{\prime}$ Utilisation Thermique D'Une Cellule, J. Nucl. Energy 6, 79 (1957).

15. H. C. Honeck, The Calculation of the Thermal Utilization and Disadvantage Factor in Uranium/Water Lattices, Nucl. Sci. Eng. 18, pp. 49-68(1964).

16. Reactor Physics Constants, ANL-5800, a. lst Edition (July 1958) and b. 2nd Edition (July 1963). 
17. L. Dressner, The Effective Resonance Integral of $\mathrm{U}^{238}$ and $\mathrm{Th}^{232}$, Nucl. Sci. Eng. 1, 68 (1956).

18. E. Hellstrand, Measurements of the Effective Resonance Integral in Uranium Metal and Oxide in Different Geometries, J. Appl. Phys. 28, 1493 (1957).

19. A. M. Weinberg and E. P. Wigner, The Physical Theory of Neutron Chain Reactors, University of Chicago Press, Chicago (1958).

20. G. G. Bilodeau et àl., PDQ--An IBM-704 Code to Solve the Twodimensional Few-group Neutron-diffusion Equations, WAPD-TM-70 (Aug 1957).

21. Harvey J. Amster, A Compendium of Thermal Neutron Cross Sections Averaged Over the Spectra of Wigner and Wilkins, WAPD-185 (1958).

22. Control Rod Materials, Power Reactor Technology 3, 3, pp. 26-47 (June 1960).

23. B. W. Colston, E. E. Gross, and M. L. Winton, "Heterogeneous Control Rod Studies," Proceedings ANNP Reactor Analysis Seminar, MND-C2487 (Jan 1961 ).

24. P. A. Ombrellaro, Effective Fast Group Cross Sections in Four Group Theory, WAPD-TM-63(1957).

25. Harvey J. Amster, Cross Sections in the SOFOCATE Code: Second Deck, WAPD-TM-67(1957).

26. D. J. Behrens, The Effect of Holes in a Reacting Material on the Passage of Neutrons with Special Reference to the Critical Dimensions of a Reactor, AERE T/R 103 (1958).

27. Q. L. Baird and W. R. Robinson, Private Communication.

28. R. E. Rice et al., Zero-power Experiments with Boiling Core B-1, BORAX-V, ANL-6689 (June 1963).

29. G. E. Putnam, TOPIC--A FORTRAN Program for Calculating Transport of Particles in Cylinders, IDO-16968 (Apr 1964).

30. R. C. Liikala, Updated RBU Basic Library, HW-75716, Vol. 1, 2, 3 (May 1963).

31. D. P. Moon, Computation Model for the EBWR Pu Recycle Experiment, internal memo randum (Aug. 3, 1964).

32. W. R. Cadwell, PDQ-3, A Program for the Solution of the Neutrondiffusion Equations in Two Dimensions on the IBM-704, WAPD-TM-179 (May 1960). 
33. B. L. Anderson, J. A. Davis, E. M. Gelbard, and P.H。 Jarvis, FLIP-An IBM-704 Code to Solve the P L and Double-P L Equations in Slab Geometry, WAPD-TM-134 (Mar 1959).

34. K. M. Case, F. deHoffman, and G. Placzek, Introduction to the Theory of Neutron Diffusion, Vol. 1 (June 1953).

35. A. D. Voorhis and T. M. Ryan, Investigation of Absorbing Membranes in Slab Reactors, TID-7532 (Oct 1957).

36. A. D. Voorhis et al., Experimental and Theoretical Study of Critical Slabs: Effect of Absorbing. Membranes of Cadmium, Gold, and Boron, WAPD-170 (Apr 1957).

37. R. E. Rice et al., Experiments on Boiling Core B-2, BORAX-V, ANL- 6849 (Oct 1964).

38. R. E. Rice et al., Experiments on Central Superheater Core CSH-1,

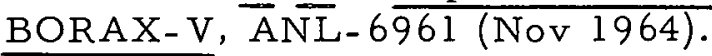

39. R. E. Rice et al., Experiments with Peripheral Superheater Core PSH- 1, BORA $\bar{X}-\mathrm{V}$, ANL-6962 (July 1965).

40. R. S. Wick, Effect of Buckling on the Multigroup Diffusion Theory Group Constants, WAPD-TM-50 (Nov 1957).

41. R. Avery, "Theory of Coupled Reactors," Proceedings of the International Conference on the Peaceful Uses of Atomic Energy, Geneva (1958), p. 1858, Vol. 12, p. 182 .

42. A. Radkowsky and R. T. Bayard, "The Physics Aspects of Seed and Blanket Core, with Examples from PWR," Proceedings of the Internation Conference on the Peaceful Uses of Atomic Energy, Geneva (1958).p. 1067, Vol. 13, p. 143 .

43. B. Carlson et al., The TDC Code, LAMS-2346 (Feb 1960).

44. J. Dwork et al., Self-shielding. Factors for Infinitely Long. Hollow Cylinders, KAPL-1262 (Jan 1955). 